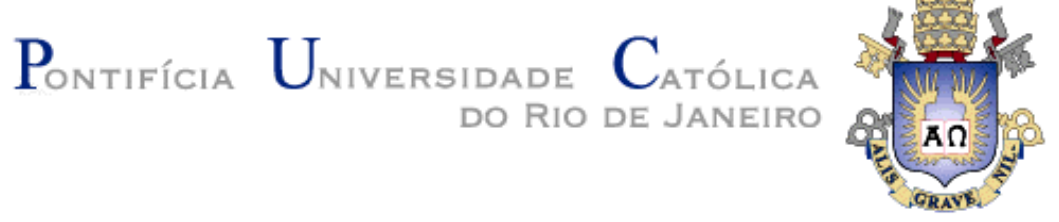

Rebeca Nonato Machado

\title{
Parentalidade e filiação adotivas: o que revelam e o que ocultam as narrativas dos pais.
}

\section{Tese de Doutorado}

Tese apresentada como requisito parcial para obtenção do grau de Doutora pelo Programa de Pós-Graduação em Psicologia (Psicologia Clínica) do Departamento de Psicologia da PUC-Rio.

Orientadora: Prof. ${ }^{\text {a }}$ Terezinha Féres-Carneiro 
Rebeca Nonato Machado

Parentalidade e filiação adotivas: o que revelam e o que ocultam as narrativas dos pais

Tese apresentada como requisito parcial para obtenção do grau de Doutor pelo Programa de Pós-Graduação em Psicologia (Psicologia Clínica) da PUC-Rio. Aprovada pela Comissão Examinadora abaixo assinada.

Profa. Terezinha Féres-Carneiro

Orientadora

Departamento de Psicologia - PUC-Rio

Profa. Andrea Seixas Magalhães

Departamento de Psicologia - PUC-Rio

Profa. Silvia Maria Abu-Jamra Zornig

Departamento de Psicologia - PUC-Rio

Profa. Aurea Maria Lowenkron Faculdade de Medicina - UFRJ

Profa. Gina Khafif Levinzon Universidade de São Paulo - USP

Profa. Denise Berruezo Portinari Coordenadora Setorial de PósGraduação e Pesquisa do Centro de Teologia e Ciências Humanas - PUCRio

Rio de Janeiro, 21 de fevereiro de 2014. 
Todos os direitos reservados. É proibida a reprodução total ou parcial do trabalho sem autorização do autor, do orientador e da universidade.

\section{Rebeca Nonato Machado}

Graduou-se na Pontifícia Universidade Católica do Rio de Janeiro em janeiro de 2005. Especialização em Terapia de Família e Casal pela CCE/PUC-Rio, concluída em 2007. Mestrado em Psicologia Clínica pela PUC-Rio, concluído em 2010.

Ficha Catalográfica

Machado, Rebeca Nonato

Parentalidade e filiação adotivas: o que revelam e o que ocultam as narrativas dos pais / Rebeca Nonato Machado ; orientadora: Terezinha FéresCarneiro. - 2014.

172 f. ; $30 \mathrm{~cm}$

Tese (doutorado)-Pontifícia Universidade Católica do Rio de Janeiro, Departamento de Psicologia, 2014.

Inclui bibliografia

1. Psicologia - Teses. 2. Adoção. 3. Parentalidade. 4. Filiação. 5. Família adolescente. 6. Fantasias. 7. Narrativas. I. Féres-Carneiro, Terezinha. II. Pontifícia Universidade Católica do Rio de Janeiro. Departamento de Psicologia. III. Título. 
Dedico este trabalho à minha família, que torna a minha vida melhor de ser vivida. 


\section{Agradecimentos}

À minha orientadora, Terezinha Féres-Carneiro, que sempre apostou no meu potencial e me ofereceu tantas oportunidades, desde a graduação. Após doze anos de trabalho juntas, receba a minha imensa gratidão.

Aos meus pais, que sempre estiveram ao meu lado e me incentivaram muito a realizar os meus sonhos profissionais.

Ao Bernardo, meu querido marido, que com seu amor não permitiu que, nos momentos difíceis, eu me deixasse vencer pelo desânimo e pelo cansaço.

Às minhas tias Ceres e Eliane, que oraram e sempre demonstraram interesse pelos meus caminhos.

A todos os meus supervisores que me acompanharam durante a minha formação clínica, em especial aos meus atuais supervisores de formação analítica, Carlos Doin e Maria Inês Escosteguy Carneiro, pelo aprimoramento de uma escuta do inconsciente sensível e complexa.

À Maria Inês Escosteguy Carneiro, pela disponibilidade e empenho em proporcionar um rico espaço de interlocução, propiciando-me maior entendimento das questões inconscientes que as narrativas dos pais voluntários encerram.

Aos meus colegas da formação na SBPRJ e da PUC, com os quais, ao longo desses anos, pude contar para trocas de ideias e indicações dos voluntários para a realização do estudo de campo.

Ao CNPq e à PUC-Rio, pelos auxílios concedidos, os quais foram fundamentais para a concretização deste trabalho.

A minha revisora Talita Guimarães Corrêa, por seu trabalho dedicado e muito afetuoso. 


\section{Resumo}

Machado, Rebeca Nonato; Féres-Carneiro, Terezinha. Parentalidade e filiação adotivas: o que revelam e o que ocultam as narrativas dos pais. Rio de Janeiro, 2014. 172p. Tese de Doutorado - Departamento de Psicologia, Pontifícia Universidade Católica do Rio de Janeiro.

A presente pesquisa teve como objetivo geral investigar a vivência de pais adotivos em relação à parentalidade e à filiação, no período da adolescência de seus filhos adotivos. Buscou-se compreender que questões relacionais se atualizam na adolescência dessas crianças que sofreram vicissitudes tão específicas, como a descontinuidade do convívio com seus genitores. A fundamentação teórica do estudo foi estruturada a partir de três eixos temáticos. O primeiro focalizou a família como uma entidade genealógica cuja constituição psíquica se organiza a partir dos processos da parentalidade e da filiação, entrelaçando as noções de narcisismo, complexo de Édipo e Interdito. No segundo eixo temático foi discutido o processo de adoção e suas repercussões psíquicas, tanto na perspectiva dos pais, quanto dos filhos, ressaltando-se a questão da elaboração dos lutos, sobretudo em relação a descontinuidades referente aos laços biológicos, e a presença do mito de origem nas famílias adotivas. O terceiro eixo correspondeu ao entendimento da adolescência como um evento intersubjetivo, que se configura como estruturante tanto para o sujeito adolescente, como para sua família. Foi desenvolvido um estudo de campo a partir de entrevistas semiestruturadas com dez sujeitos independentes, oito mães e dois pais adotivos, todos pertencentes às camadas média e alta da população do Estado do Rio de Janeiro. Os filhos adotivos desses sujeitos se encontravam no período da adolescência, entre os 13 e 18 anos. Para a análise das entrevistas, foi utilizado o método de análise de conteúdo. Dos dados obtidos, emergiram sete categorias de análise: motivações manifestas e latentes, informações sobre a adoção, mito de origem, identificação e identidade, rede de apoio, parentalidade na adolescência 
e, por fim, o "insondável". Os resultados mais significativos ressaltaram a presença da ambiguidade na parentalidade e na filiação, a dificuldade de legitimar a parentalidade adotiva, assim como uma forte desconsideração da existência de um registro das experiências primitivas do bebê. Um fator encontrado, que se mostrou muito produtivo, foi a sensibilidade dos pais em reconhecer a curiosidade do filho sobre sua origem e a sensação de duplo pertencimento.

\section{Palavras-chave}

Adoção; parentalidade; filiação; família adolescente; fantasias; narrativas. 


\section{Abstract}

Machado, Rebeca Nonato; Féres-Carneiro, Terezinha (Advisor). Parenting and adoptive filiation: what the narratives of parents reveal and conceal. Rio de Janeiro, 2014. 172p. Doctorate Thesis Departamento de Psicologia, Pontifícia Universidade Católica do Rio de Janeiro.

The present research aimed to investigate the experience of foster parents related to parenting and filiation, in the adolescence period of their adopted children. It was sought to understand that relational issues update on the adolescence of those children who have suffered such vicissitudes, as the discontinuity of coexisting with their genitors. The study theoretical foundation was structured from three thematic axes. The first focused on the family as a genealogic entity whose psychic constitution is organized from the parenting and filiation process, gathering notions of narcissism, Oedipus complex and Interdict. In the second main theme was discussed the adoption process and its psychological repercussions, both from the parents perspective, as the children, emphasizing the issue of grief, particularly in respect of discontinuities concerning the biological ties, and the presence of the myth of origin in adoptive families. The third axis corresponded to the understanding of adolescence as an intersubjective event, which is configured as structuring both for the teenager as for the family. A field study was developed from semi-structured interviews with ten independent subjects, eight adoptive mothers and two adoptive fathers, all belonging to the middle and upper layers of the state of Rio de Janeiro population. The adopted children of these subjects were in the adolescence period, between 13 and 18 years old. For the interviews analysis, the method of content analysis was used. Seven categories of analysis emerged from the data obtained: manifest and latent motivations, information about the adoption, myth of origin, identity and identification, support network, parenting in adolescence and, finally, the "unfathomable". The most significant results underscored the presence of 
ambiguity in parenting and filiation, the difficulty of legitimizing adoptive parenting, as well as a strong disregard for the existence of a baby primitive experiences record. One factor found, which proved to be very productive, was parental sensitivity to recognize the children's curiosity about their origin and the sense of dual belonging.

\section{Keywords}

Adoption; parenting; filiation; teen family; fantasies; narratives. 


\section{Sumário}

1. Introdução

2. Laços de parentesco: bases psíquicas fundantes 19

2.1 A identificação: primeira expressão do laço emocional

2.2 A interdição do incesto e o narcisismo: condições para o laço de parentesco

2.3 Filiação e parentalidade: o devir a ser na cadeia geracional 32

3. A adoção e os possíveis desdobramentos na trama familiar

3.1 Antecedentes da adoção: descontinuidades biológicas e demandas de vínculo

3.2 A parentalidade e a filiação adotivas: conflitos e fantasias 55

3.3 Informações sobre a adoção e o mito de origem

3.4 O papel da família extensa e da rede social

4. A adolescência em questão

4.1 Processos intrapsíquicos do adolescer $\quad 79$

4.2 $O$ adolescente e o ambiente familiar na obra de Winnicott 83

$\begin{array}{ll}\text { 4.3 A família adolescente } & 91\end{array}$

5. Estudo de campo 98

$\begin{array}{ll}5.1 \text { Sujeitos } & 99\end{array}$

5.2 Instrumentos e procedimentos 102

5.3 Análise e discussão dos dados 103

5.3.1 Motivações manifestas e latentes $\quad 105$

5.3.2 Informações sobre a adoção 111

5.3.3 Mito de origem 117

5.3.4 Identificação e identidade 128

5.3.5 Rede de apoio 135

5.3.6 Parentalidade na adolescência 142 
6. Considerações finais 155

7. Referências bibliográficas 162

8. Anexos 


\section{INTRODUÇÃO}

A adoção vem se apresentando como um tema recorrente em discussões de diversos setores da sociedade contemporânea, tanto em estudos científicos, em meios de comunicação, quanto no campo jurídico e até mesmo no setor de entretenimento, como as novelas. Colocar em discussão este tema contrapõe o posicionamento de uma época anterior, durante a qual o "não dito" prevalecia, manifestando uma visão social predominantemente preconceituosa e estereotipada. Segundo Gagno e Weber (2003), a escassez científica, principalmente no Brasil, teve um efeito considerável nas representações sociais sobre o tema, com sérias consequências para as famílias adotivas e para as crianças que esperavam ser adotadas.

Nos últimos anos, muitas transformações ocorreram, principalmente com relação às práticas e às regulamentações legais da adoção. Atribui-se a origem desta evolução ao fato de se ter adotado um enfoque social para atender às necessidades de crianças desprovidas dos seus direitos. A promulgação do Estatuto da Criança e do Adolescente (ECA), em 1990, visando à proteção integral da criança e do adolescente, constitui um marco para a efetivação desses princípios. Costa e Rossetti-Ferreira (2007) mencionam que, a partir daí, uma nova cultura emergiu, tendo como premissa a busca de uma família para a criança, e não mais uma criança para as demandas da família. E, assim, a adoção vem se tornando cada vez mais um tema relevante de ser acompanhado cientificamente, enquanto fenômeno social e representante das variadas configurações familiares.

Particularmente, a atenção que demos ao tema da adoção ocorreu ao longo de um atendimento psicológico a uma adolescente de 13 anos que era adotada, configurando uma inquietante experiência clínica. Na primeira entrevista com a adolescente acompanhada da mãe, esta última se queixava do mau comportamento da filha, o qual se caracterizava pelas notas baixas, pelo recente desentendimento com os amigos da escola e por suas atitudes desafiadoras para com a autoridade dos pais, levando-os até a brigar entre si por causa da filha. Outros psicólogos já tinham sido consultados. Alguns deles avaliaram que não havia necessidade de iniciar um tratamento, pois se tratava de uma menina com questões comuns à fase de seu desenvolvimento. 
Na primeira entrevista, a menina não apresentava uma demanda própria de tratamento e "nada" parecia fugir de questões peculiares à crise da adolescência. Em uma das entrevistas preliminares apenas com a adolescente, ela relatou que tinha medo de filmes de terror, mas ao mesmo tempo estes a atraíam. Destacou que $O$ chamado - partes 1 e 2 foram os filmes que mais a aterrorizavam, deixando-a noites sem dormir. Após uma breve pesquisa sobre o enredo, foi possível perceber que não era aleatória a representação aterradora desses filmes para ela, pois alguns elementos da história davam subsídios às suas fantasias inconscientes.

O enredo versa sobre várias mortes de pessoas, logo após assistirem a uma determinada fita de vídeo. Com o desenrolar da história, é desvendado que, nessa fita, fora registrada a trágica história de vida de uma menina chamada Samara, cujo espírito cheio de ódio fazia com que ela matasse todos os que se colocavam em seu caminho. A mãe biológica de Samara acreditava que a filha tinha nascido possuída por um espírito maligno, e por isso deveria matá-la. Mas a criança foi salva dessa tentativa de filicídio e colocada para adoção. Sua família adotiva criava cavalos, que começaram a morrer após a chegada de Samara. A mãe adotiva, com a falência financeira, passou a acusar a menina de ser responsável pelo ocorrido, decidindo jogá-la dentro de um poço. Após inúmeras tentativas de acabar com a maldição, a qual é dissipada por uma fita de vídeo, descobre-se que, na verdade, o que o espírito de Samara deseja é ter uma mãe.

Podemos pensar o enredo desse filme como um sonho, que revelava conteúdos inconscientes e fantasias assustadoras da adolescente. A hipótese era que a adolescente se identificava com o espírito de Samara, rejeitada pelas mães (adotiva e biológica), acreditando que desencadeava o mal, a discórdia familiar.

De forma muito concisa, descrevemos um elemento significativo na vida psíquica dessa adolescente e a compreensão clínica, ainda incipiente à época. Após muitos impasses, houve uma interrupção do atendimento, solicitada pela mãe. Essa brusca interrupção exigiu um imenso trabalho de luto, além da necessidade de lidar com a dor de nem mesmo ter sido possível realizar a despedida da jovem paciente.

Esse caso clínico, portanto, é uma das principais fontes inspiradoras para o desenvolvimento desta pesquisa. Após uma longa reflexão, compreendemos que este trabalho representa uma tentativa de elaboração dessa experiência clínica, 
mas também uma tentativa de reparação do fracasso decorrente do despreparo para lidar com essa família. Sendo assim, a motivação visceral deste estudo sobre a adoção vai muito além de uma pesquisa sobre relações familiares ou um fenômeno social. A motivação tem como base a dificuldade de se lidar com o não saber, a incompreensão e as perguntas inquietantes: "Por que foi desse jeito e não de outro? O que deu errado"?

Como objetivo geral deste estudo, propomos investigar, prioritariamente, a vivência de pais adotivos em relação à parentalidade e à filiação justamente no período da adolescência de seus filhos adotivos. Isso por se tratar de um período do desenvolvimento no qual reaparecem questões relacionais primitivas irresolutas. Perguntávamos que questões relacionais se atualizariam na adolescência dessas crianças adotivas que, necessariamente, sofreram vicissitudes tão específicas, como a descontinuidade de conviverem com seus genitores.

Tínhamos, inicialmente, o projeto de investigar a vivência da parentalidade e da filiação a partir da perspectiva tanto dos pais como dos filhos adotivos. Contudo, ao longo da realização do estudo-piloto, foi muito difícil encontrarmos adolescentes que se dispusessem a participar de entrevistas.

Diante desse obstáculo, foi preciso modificar o objetivo geral para viabilizar a realização do estudo. Portanto, a pesquisa apoia-se na tentativa de compreender, pelo ponto de vista de pais e de mães adotivos, como é a vivência da parentalidade e da filiação adotiva diante das rupturas e das transformações características da adolescência, um período reconhecidamente crítico, porém estruturante no desenvolvimento do sujeito e da família.

Entre os objetivos específicos, buscamos estudar: a) os processos da parentalidade e da filiação inseridas em uma trama geracional; b) as representações simbólicas da adoção e suas repercussões; c) as idiossincrasias da adolescência e seus efeitos no vínculo parental-filial. Segundo Lévy- Soussan (2006), a adolescência é um momento decisivo, não apenas para o processo de subjetivação do adolescente, mas também para o trabalho psíquico próprio da filiação e da parentalidade. O olhar intersubjetivo para tais questões é um diferencial no trabalho clínico com as famílias adotivas.

Para a realização do estudo de campo, foram entrevistados dez sujeitos independentes, oito mães e dois pais adotivos, todos pertencentes às camadas média e alta da população do Estado do Rio de Janeiro. Os filhos adotivos desses 
sujeitos se encontravam no período da adolescência, entre os 13 e 18 anos, conforme postulado por Emmanuelli (2005). Como instrumento de pesquisa, criamos uma entrevista semiestruturada, cujo "roteiro invisível" foi delineado a partir da fundamentação teórica previamente estudada. Para o desenvolvimento da análise dos dados obtidos nas entrevistas, utilizamos o método de análise de conteúdo (BARDIN, 1977/2010), procurando compreender, no material discursivo, os significados manifestos e latentes. Analisamos as entrevistas buscando pensar o que as narrativas revelavam e ocultavam. A fundamentação teórica está, predominantemente, respaldada em abordagens teóricas da Psicanálise e da Psicoterapia de Família e Casal, tendo sido estruturada sob três eixos temáticos.

O primeiro eixo, desenvolvido no segundo capítulo, teve como enfoque o entendimento da família como uma entidade genealógica que designa funções e papéis para seus componentes, sendo a cadeia geracional constituída pelos processos psíquicos da parentalidade e da filiação (LEGENDRE, 1985, 1990, 1992; FREUD, 1914, 1921). Por genealogia, entendemos a organização simbólica da história do sujeito, através de suas duas linhagens, a paterna e a materna. A genealogia inclui cada geração em seus devidos papéis, com atribuições e proibições. No plano simbólico, os lugares na cadeia genealógica não são um direito adquirido, e sim uma questão em aberto, já que dependem de como o sujeito e o grupo familiar irão ocupá-los.

Para falarmos sobre a formação de um grupo familiar na sociedade ocidental, acreditamos ter sido importante desenvolver a compreensão de três conceitos psicanalíticos fundamentais para a estruturação do sujeito e, consequentemente, para o estabelecimento de um vínculo: a identificação, o narcisismo e o interdito. A abolição, pelo sujeito, de um narcisismo radical, no qual somente olhe para si mesmo, é imprescindível para que haja o reconhecimento da existência do outro, o que se dá mediante a identificação. Recorrendo às formulações de Freud, entendemos a identificação como o processo de criação originária do laço afetivo com o objeto, sendo por meio dela que os membros de um grupo se ligam entre si. A interdição do incesto também participaria da sustentação de condições para se viver em sociedade e, consequentemente, se viver em família. Logo, o interdito corresponde à proibição 
do desejo humano do impossível, da total satisfação, reivindicando a onipotência mítica dos primórdios da vida.

Pensamos que foi necessário desenvolver os conceitos acima descritos para entendermos de uma maneira complexa os processos psíquicos da parentalidade e da filiação. Defendemos a ideia de que a parentalidade não pode ser pensada sem a filiação, porque para ser pai é preciso existir o filho. Dessa maneira, consideramos que ambos os processos sejam constituídos a partir de uma relação dialética. A nosso ver, parentalidade corresponde à organização psíquica dos pais diante de seu filho e de sua condição de pai. Ou seja, demarca a ocorrência de reposicionamentos geracionais e de mudanças psíquicas do que é vir a ser pai e ser mãe, trazendo uma nova vivência para o sujeito. Compete ainda aos pais organizar o pensamento da criança, inserindo-a em uma cadeia geracional de filiação que the possibilite reconhecer as diferenças, como, por exemplo, a diferença entre as gerações.

Quanto ao segundo eixo, elaborado no terceiro capítulo, o foco de discussão foi o processo de adoção e suas repercussões psíquicas (TRINDADESALAVERT, 2010; LEVY, 2009; LÉVY-SOUSSAN, 2006; MARINOPOULOS, SELLENET e VALLÉE, 2003; HAMAD, 2001). O lugar psíquico designado ao filho adotivo na cadeia geracional se apresenta como uma das questões centrais nas famílias adotivas, descrita na literatura (TRINDADE-SALAVERT, 2010; LEVY, 2009; FILHO, 2008; LEVINZON, 2000). Torna-se fundamental que os pais insiram simbolicamente o filho adotivo na trama psíquica geracional, de modo que ele possa desenvolver o sentimento de pertença e de afiliação ao grupo familiar.

Pensamos que a condição da parentalidade e da filiação adotivas seja um desafio, na medida em que a família constantemente se depara com o que está "solto", dissociado e faltante, como, por exemplo, a filiação biológica em relação aos eixos de filiação jurídicos e afetivo-imaginários (LÉVY-SOUSSAN, 2006). Kernberg (1985) afirma que a criança adotiva possui duas incógnitas em sua vida. A primeira diz respeito ao desconhecimento de quem foram seus pais biológicos. A segunda corresponde às razões da descontinuidade da convivência com seus genitores. Devido à presença dessas incógnitas, percebemos que a questão do mito de origem permanece pungente nas famílias adotivas, e por isso foi necessário investigar esta noção. 
Formulamos, também, algumas ideias sobre fatos que necessariamente estão presentes na constituição dessas famílias. Como, por exemplo, a existência de uma ruptura entre a descendência e a ascendência biológicas, as profundezas das motivações inconscientes que alicerçam a demanda de um filho, e o paradoxo de precisar de desencontro para haver o encontro entre pais e filhos.

Por fim, o terceiro eixo teórico, que compõe o quarto capítulo, centra-se na concepção da adolescência como um evento intersubjetivo, o qual é estruturante para o sujeito adolescente, bem como para sua família (EMMANUELLI, 2005; BENGHOZI, 1999). Segundo Benghozi (1999, 2005), os vínculos familiares, em determinados momentos, podem sofrer um dilaceramento diante de uma crise narcísica de ordem grupal. O período da adolescência configuraria um desses momentos, já que representa uma crise narcísica ao mobilizar o legado e transformar a identidade familiar, exigindo a construção de uma nova "pele" grupal.

Vimos o quanto Erikson (1971) é referência para os autores contemporâneos, quando consideram a adolescência como um período que se situa na fronteira entre o "normal" e o "patológico". Isso justifica a possibilidade de falarmos em um caráter de "crise normativa" na adolescência. Adicionando a estas considerações, podemos pensar o efeito da adolescência na estrutura do sistema familiar, trazendo elementos novos que desorganizam o grupo, colocandoo à prova. $\mathrm{O}$ adolescente se depara com pressões externas e internas, porém ainda são poucos os autores que estudam como tais pressões são vivenciadas pelos pais dos adolescentes. Por isso, desenvolvemos algumas das formulações de Winnicott (1971, 1965, 1963, 1951), por considerá-lo um dos pioneiros a pensar a adolescência sob uma perspectiva que valoriza a participação do ambiente para a qualidade desta passagem. Não descrevemos de forma ampla o entendimento da psicodinâmica individual, por supormos que seria mais oportuno desenvolver as ideias dentro de concepções intersubjetivas, já que as entrevistas ocorreram com os pais e não com os adolescentes.

Ancorados na teoria winnicottiana, concebemos que o grupo familiar deve sobreviver aos ataques característicos do adolescente, suportando, por exemplo, que os investimentos libidinais se desloquem das figuras parentais para as figuras sociais. Este movimento para fora do núcleo familiar, quando sustentado por seus integrantes, permite a consolidação do eu e a individuação do jovem. Quando os 
pais são incapazes de resistir à destrutividade e à separação dos filhos, por se sentirem ameaçados e impotentes, eles promovem a fantasia, no adolescente, de que os efeitos desses movimentos são irreparáveis, intensificando o sentimento de culpa inconsciente pela destruição do objeto (MARTY, 2006). E quanto às famílias adotivas, haveria alguma especificidade? Filho (2008) descreve que as crianças adotadas vivenciam a adolescência com mais conflitos, os quais, segundo ele, são resultado do enigma de sua origem.

Mesmo com todo o avanço teórico sobre a adoção, consideramos que ainda são poucas as produções científicas que tratam dos temas adoção e adolescência, principalmente sob uma perspectiva intersubjetiva. Por meio desta investigação, buscamos ter acesso a dados que auxiliem a compreensão de questões vividas pelas famílias adotivas no período da adolescência, procurando evitar os estereótipos que circundam esses dois temas.

Acreditamos que o desenvolvimento deste estudo oferece subsídios para psicoterapeutas e para outros profissionais interessados nessas questões. Pensamos ser urgente a ampliação de pesquisas neste campo, de modo que sejam fortalecidos trabalhos especializados e uma escuta consistente sobre a complexidade do discurso das famílias adotivas. Conceitos diversos sobre o que é adotar, ser adotado, ser mãe e pai adotivos, ser filho adotivo, estão disseminados pela sociedade contemporânea. Para compreender a sua face mais verdadeira e profunda, é importante analisar o que revelam e o que ocultam as narrativas sobre o tema. 
2.

\section{LAÇOS DE PARENTESCO: BASES PSÍQUICAS FUNDANTES}

A família é o primeiro sistema de socialização do sujeito, constituindo a sua primeira manifestação cultural. Tal manifestação resulta de um funcionamento intersubjetivo, marcado por um percurso genealógico. É por esse percurso, situado dentro de um espaço-tempo, que se consolidam a transmissão de representações simbólicas entre as gerações e a condição de se viver em sociedade.

Uma das principais funções familiares é promover um ambiente que permita um processo de desenvolvimento suficientemente bom para o sujeito, propiciando-lhe amadurecimento emocional, capacidade de individuação e de socialização. A inserção do sujeito em uma linhagem genealógica, estabelecendo o "sentimento de pertença", é o alicerce de sua subjetividade. Isso significa pertencer a uma família, a uma história, o que viabiliza a capacidade de reconhecer a si mesmo e de se diferenciar.

Legendre (1985), com seu conhecimento sobre a história do Direito e sobre os fundamentos teóricos da psicanálise, afirma que a família tem como princípio colocar em ordem as representações dos ancestrais e os referenciais sociais, indicando ao sujeito como ele deve funcionar na organização social. Portanto, a família é uma instituição responsável pelas questões referentes às identidades, designando funções e papéis, que são nomeados e impregnados de valores.

A família é juridicamente legitimada e vigiada. Complementando essas ideias sobre o contexto da sociedade ocidental, Legendre (1985) pontua que a genealogia deve ser considerada um princípio institucional, por introduzir práticas dogmáticas que gerenciam um discurso produtor de uma verdade. Esse discurso é transplantado para as práticas jurídicas, que passam a gerenciar as práticas familiares.

As práticas jurídicas seriam uma forma social consagrada de barrar os anseios pulsionais. De acordo com Legendre (1985), são as práticas jurídicas que estabelecem um elo entre o biológico, o social e o inconsciente. Para o autor, a condição de viver a vida em sociedade é estabelecida a partir desse elo tridimensional. Por conseguinte, é a genealogia que nutre a sociedade com a 
transmissão de uma ficção fundante, cabendo à instância jurídica reassegurar o discurso normatizante.

Há nessa normatização um ponto espinhoso, pois, ao mesmo tempo em que serve como uma alavanca para toda a sociedade, também aniquila o sujeito. Quando falamos em sujeito, está implícito o entendimento de que seja um ser humano organizado pela lógica do inconsciente e toda a ebulição de sua vida pulsional. Esta última deve ser impedida por um discurso predeterminado, de maneira que as referências genealógicas não sejam esvaziadas de conteúdos, nem subvertidas. Se por outro lado, devemos considerar uma conquista do sujeito criar uma identidade separada de sua instituição genealógica, a mesma é atingida, quando ele se identifica com seus semelhantes.

\section{1}

\section{A identificação: primeira expressão do laço emocional}

O vocábulo “identificação" é polissêmico, por isso sua compreensão tornase complexa. É possível apresentar, no mínimo, três principais sentidos do termo: reconhecer a natureza de algo ou alguém, ação de se reconhecer como algo ou alguém, considerar a semelhança entre algo ou alguém (EIGUER, 2012). Como conceito, a identificação foi formulada por Freud para qualificar um processo que constitui e transforma o sujeito, por meio da apropriação de atributos ou traços de pessoas, em determinados momentos de seu desenvolvimento. Esse processo participa da constituição das relações objetais, portanto, da constituição da subjetividade. Sendo assim, a identificação marca o futuro do vir a ser, pois dependerá do que será e de como será organizado, no psiquismo da criança, o legado de seus ancestrais.

Ao longo da obra freudiana, esse processo de identificação passou a ter gradativamente um papel importante. Roudinesco (1998), no Dicionário de psicanálise, descreveu, de forma sucinta e cronológica, o conceito em questão na obra de Freud, auxiliando-nos a compreender seu desenvolvimento. A autora menciona que Freud usa o termo, pela primeira vez, em uma carta para Fliess em 1896, porém de forma descritiva, não o formulando por meio da metapsicologia. Nessa época, a identificação foi descrita como o desejo recalcado de "agir como" ou de "ser como alguém". 
Em 1900, com A interpretação dos sonhos, Freud inicia uma elaboração teórica sobre a identificação, ao interpretar o sonho de uma mulher no qual esta não realiza um de seus desejos. Contudo, devido às distorções dos sonhos, Freud analisa que há uma identificação da mulher com a amiga que desejava engordar. O seu desejo era que a amiga não engordasse, por temer que isso pudesse atrair os olhares de seu marido açougueiro, que gostava de mulheres fartas. Neste caso, trata-se de identificação histérica (ROUDINESCO, 1998).

Entretanto, foi apenas no texto Sobre o narcisismo: uma introdução, que a identificação apareceu como uma ação fundamental para o sujeito. Aproveitando o que tinha formulado em 1895, Freud (1914) afirma que inicialmente o sujeito é a imagem do outro, não havendo diferenciação, porque tudo isso acontece no estado narcísico. Para ele, a inauguração da vida psíquica do sujeito se dá na relação com um outro semelhante, o primeiro objeto satisfatório e também hostil. O sujeito se reconhecerá através do semelhante, perceberá o objeto como ele próprio.

A primeira identificação é, portanto, com essa imagem especular, que formará um dos primeiros modelos que o ego se esforçará para alcançar. Como conceitua Freud (1885), há um interesse primitivo em estabelecer a situação de satisfação que leva à saída "da situação perceptiva dada na realidade à situação que é desejada" (p. 384). A partir desse pressuposto é criada uma montagem mítica de um eu ideal, amado incondicionalmente, representando a onipotência narcísica.

Depois, em Psicologia de grupo e análise do eu, Freud (1921) escreve um capítulo sobre a identificação, concebendo-a como uma expressão primária de um laço emocional com outra pessoa. O autor pontua e diferencia três tipos de identificação. A primeira está presente no período pré-edipiano, sendo denominada de identificação primária. Trata-se da criação originária do laço afetivo com o objeto, justamente na fase oral, na qual o objeto é incorporado como no modelo canibalesco.

O segundo tipo de identificação, que Freud (1921) designou como regressiva, é evidenciada no sintoma histérico, cuja formação se verifica pela imitação de um sintoma da pessoa amada. Ele assim a denominou porque é como se o investimento libidinal da escolha de objeto retroagisse e a identificação 
ocupasse o seu lugar. Nessas situações, Freud ressalta que a identificação pode tomar emprestado um único traço do objeto, nomeado de "traço único".

Por fim, o terceiro tipo de identificação é estabelecido sem qualquer investimento sexual no outro. O sujeito cria um laço não pelo impulso sexual, mas pela identificação. Portanto, esse terceiro tipo de identificação ocorre, especialmente, no contexto dos grupos afetivos. É por meio dessa identificação que os membros de um grupo se ligam entre si (ROUDINESCO, 1998).

De acordo com Freud, os processos envolvidos para a construção de um grupo são: a identificação entre os membros, "baseada numa importante qualidade emocional comum" (FREUD, 1921, p. 136), e a idealização do líder. Neste sentido, percebemos que o papel que a identificação desempenha é uma importante variante no estabelecimento do interjogo sujeito-objeto. Justamente por isso, a identificação é um conceito fundamental no desenvolvimento da teoria e da prática das escolas intersubjetivistas, que buscam ressaltar o quanto o psiquismo de dois, ou vários, sujeitos funciona em reciprocidade, influenciando-se em diversos planos: afetivos, de desejos, entre outros (EIGUER, 2012).

É possível evidenciar o quanto o processo de identificação perpassa o complexo de Édipo. Daí ser muito difícil falar em identificação e não mencionar seu lugar no complexo de Édipo, visto como um processo tão fundamental para a construção do grupo. Na fase edípica, o menino toma o pai como seu ideal, querendo crescer como ele. Nesse período, dois laços distintos convivem ao mesmo tempo, o investimento de objeto sexual para com a mãe e uma identificação com o pai, tomando-o como modelo. O menino nota que o pai está no caminho de sua escolha objetal, ele identifica-se com o pai pelo desejo de substituí-lo na relação com a mãe, e disso resulta um sentimento de hostilidade.

Estas identificações formam uma estrutura complexa na medida em que o pai e a mãe são, cada um por sua vez, objeto de amor e de rivalidade. Aliás, é provável que esta presença de uma ambivalência em relação ao objeto seja essencial à constituição de qualquer identificação (LAPLANCHE, 2001, p. 228).

Portanto, há ambivalência na identificação, por ser concomitantemente "uma expressão de ternura com tanta facilidade, quanto um desejo do afastamento de alguém” (FREUD, 1921, p. 133). Ou seja, ao mesmo tempo em que realiza uma ligação ao objeto, a identificação promove um afastamento, pelo fato de o sujeito desejar vir a ser o objeto. Freud (1921) enfatiza a diferença entre a 
identificação e a escolha objetal. Na primeira existe o desejo "de ser", toma-se para o eu um traço do objeto que fora apanhado como modelo. Na segunda há o desejo "de ter" o objeto sexual.

O desejo hostil de ocupar o lugar da mãe por parte da menina, sob influência do sentimento de culpa, produz o sintoma que expressa seu amor objetal pelo pai. O sintoma é justamente identificar-se com um "traço único" do pai, substituindo a escolha de objeto. Ou seja, por haver repressão e mecanismos do inconsciente, "a escolha de objeto retroage para a identificação: o ego assume as características do objeto" (FREUD, 1921, p. 135).

Freud (1924), no artigo "A dissolução do complexo de Édipo", estabelece claramente a distinção entre o investimento do objeto e a identificação. As catexias de objeto são abandonadas e substituídas por identificações, quando existe a percepção da castração. Dessa maneira, por meio da substituição desses investimentos pela identificação, é marcada a saída do complexo de Édipo. A autoridade do pai, ou dos pais, é introjetada no ego a partir da castração, formando o núcleo do superego. Este exerce a severidade do pai e proíbe o incesto, defendendo assim o ego do retorno da catexia de objeto. As catexias libidinais presentes no complexo de Édipo são em parte dessexualizadas e sublimadas, e também são em parte transformadas em impulsos de afeição - o terceiro tipo de identificação descrito anteriormente.

De acordo com Roudinesco (1998), Freud declara, no texto A dissecção da personalidade psíquica, de 1933, que o processo de identificação é um processo complexo e de difícil formulação, definindo-o como "a ação de assemelhar um ego a outro ego" (FREUD, 1933, p. 68). Ele não se contenta com os estudos realizados até então e formula que a identificação seria a base do superego. Considera essa instância "um exemplo de identificação bem-sucedida com a instância parental" (FREUD, 1933). O superego surge como herdeiro da vinculação afetiva do complexo de Édipo.

Freud (1933) relembra que o menino irá se identificar com o pai, caso queira "ser" igual ao pai, mas, se escolhê-lo como objeto, a escolha passará pelo nível do "ter", ou seja, possuir esse pai, e não pelo nível do "ser". Ele enfatiza que a diferença entre escolha objetal e identificação não as torna excludentes. Elas podem conviver lado a lado, como, por exemplo, na identificação "com alguém que foi tomado como objeto sexual", modificando o ego do sujeito (p. 69). 
Nesta trajetória sobre o processo de identificação, vimos a sua participação na constituição da subjetividade, na entrada e na saída do Édipo, assim como nos primórdios do laço emocional com o objeto. A partir dessa compreensão, entendemos a identificação como um processo estruturante dos laços de parentesco. Os pais propõem inconscientemente seu modelo pessoal, mas sairão profundamente tocados em sua interação com o filho, e até mudados no fim desse processo (EIGUER, 2012).

Falamos da identificação pela ótica do bebê (sujeito em devir) ligando-se ao objeto. Entretanto, o objeto (mãe/pai) também precisa se ligar ao bebê para poder oferecer-lhe investimento libidinal, sendo este viabilizado por meio da identificação. Ocorre no psiquismo da mãe a evocação de sua infância e das relações que ela teve com a própria mãe, provocando uma regressão psíquica, que a conduz a se identificar com seu bebê a partir do bebê que ela mesma foi. A mãe vai sentir o desejo de amar e cuidar de sua criança como ela teria desejado ser amada, gratificando seu narcisismo.

Também será necessário que a mãe designe o pai como genitor da criança e que este assinale a mãe em sua função. É um reconhecimento mútuo, em que cada um dos pais considera o outro em condições de servir de modelo de identificação para a criança. Ou seja, existem mútuas identificações, e esse jogo de identificações permite à mãe e ao pai adaptarem-se às necessidades do bebê, transmitindo seu próprio narcisismo e possibilitando que a criança construa um caminho de narcisismo próprio (SOLIS-PONTON, 2004). Na prática clínica, Eiguer (2012) afirma que quando a mãe ou o pai negam a função do outro, aquele que não tem a função reconhecida pode ser rejeitado pelo filho. Nesta situação, fica difícil tomá-lo como modelo de identificação e, com isso, pode se instalar a violência na família.

Constatamos, a partir desse entendimento, que a identificação com o objeto e do objeto com o bebê é um mecanismo que marca este estado primordial da vida. Nos primórdios do laço de parentesco, o jogo de identificações compõe um processo estruturante em duas vias: uma para o psiquismo da criança, ao mesmo tempo em que estrutura no psiquismo da mulher a vivência simbólica do ser mãe de sua criança. Há um jogo do reconhecer e ser reconhecido, viabilizando dessa forma o reconhecimento do semelhante e a ligação libidinal com ele. Portanto, neste trabalho, compreendemos os processos psíquicos estruturantes pela 
perspectiva da intersubjetividade, segundo a qual estes são determinados e sobredeterminados pela intersubjetividade entre pais e filhos, e, de forma mais abrangente, entre os diferentes membros da família (EIGUER, 2012).

O vínculo familiar é a composição das interações entre dois ou mais sujeitos, no entrecruzamento de suas identificações. Trata-se aqui de uma estrutura que enquadra uma série de representações e narrativas que compõem a identidade grupal, os ideais comuns, também ligados a hábitos, crenças e tradições sociais. Eiguer (2012) formula que, a partir dessa interação, um terceiro elemento é criado, como o terceiro analítico desenvolvido por Ogden (1996). A esse terceiro elemento Eiguer denominou, usando uma metáfora, de cúpula do vínculo, que é um conjunto em movimento de produções inconscientes, igualmente presente nas participações do sujeito em qualquer relação, tais como amizades, trabalho e associações. A cúpula do vínculo é continente e reguladora das paixões edipianas na família. Para os pais, é interessante encontrar um equilíbrio entre o lugar distinto que eles ocupam na cadeia genealógica e as identificações com seus próprios pais e antepassados, tendo, além disso, de renunciar aos seus impulsos (EIGUER, 2012). Esse resultado é que formará o legado que a criança irá herdar e a inspirará a formar sua subjetividade, que é amplamente inconsciente.

\section{2}

\section{A interdição do incesto e o narcisismo: condições para o laço de parentesco}

Para serem criadas condições de se viver em sociedade e, consequentemente, se viver em família, dois processos psíquicos são de crucial importância. O primeiro é a interdição do incesto relacionada ao desejo humano do impossível, da total satisfação, reivindicando a onipotência mítica dos primórdios da vida. O segundo processo é a abolição, no sujeito, de um narcisismo radical, que o faz olhar somente para si mesmo, impedindo-o de reconhecer a existência do outro. Se não houver um limite nestas duas questões, entrará em cena a tragédia familiar, pois tanto o interdito quanto o reconhecimento do semelhante representam o limite, determinando uma ordem nos grupos humanos. 
A discussão sobre o desejo do incesto, o interdito e o narcisismo é fundamental para entendermos a estruturação do sujeito, bem como a trama dos conteúdos psíquicos presentes no romance familiar. É nessa montagem inconsciente, denominada de ficção fundante por Legendre (1985), que se constitui o jogo conflituoso. Essa ficção fundante influencia a maneira como os membros familiares ocupam seus lugares e suas funções na linhagem genealógica.

Entendemos que essa ficção fundante é transmitida através das gerações como uma maneira de manter a cultura, correspondendo à interdição do incesto, cuja temática fora desenvolvida por Freud, principalmente em Totem e tabu (1913-1914). Nesse texto, Freud formula a filogenia do complexo de Édipo por meio de uma "horda primeva", na qual as fantasias incestuosas eram interditadas pela existência de algo real, e não uma lei. Ao narrar o percurso das práticas primitivas, Freud desenvolveu uma perspectiva mitológica, contextualizando a origem da civilização.

O laço de união nos povos primitivos era concreto, pois era preciso realizar as refeições de sacrifícios para a existência de um vínculo, ou seja, concretizar o pertencimento ao clã. Segundo Freud (1913-1914), "havia apenas uma espécie de laço que era absoluto e inviolável: o do parentesco" (p. 139). O parentesco envolvia a vida comum, a participação em algo partilhado, e quando comiam a mesma refeição oferecida ao deus primitivo, tinham o sentimento de pertencer a uma só substância.

O interessante é que Freud (1913-1914), nesse mesmo texto, diferencia parentesco de vida familiar, sendo o primeiro o mais antigo, uma vez que as famílias primitivas eram formadas por vários parentescos (clãs). O parentesco era definido por meio do sacrifício de um animal, cuja incorporação representava a renovação e o asseguramento da semelhança entre seus integrantes.

O animal totêmico, dentro da perspectiva psicanalítica, é um substituto do pai tirânico. De acordo com o mito, a "horda primeva" era governada por um pai onipotente, que satisfazia seus desejos sexuais com todas as mulheres que o cercavam. Ele impedia seus filhos de realizarem tal desejo, castrando-os quando se mostravam como rivais. Certa vez, os irmãos, que tinham sido expulsos do clã, se reuniram para matar o pai temido e invejado, acabando com o poder patriarcal.

Contudo, eles não só cometeram o parricídio, como também devoraram o pai para incorporar as forças deste. Com o assassinato e o canibalismo, os filhos 
primitivos efetivaram concretamente a internalização do pai. O mito da horda primeva permitiu a Freud compreender a importância da internalização do pai, da lei, o que, no desenvolvimento psíquico, significa uma conquista para adquirir a capacidade de simbolização e a castração (BRUNNER, 2000).

Após o parricídio, os irmãos perceberam que a horda poderia se desintegrar caso houvesse uma guerra entre eles, motivada pelo desejo que tinham de ocupar o lugar vazio do pai e desfrutar do privilégio sexual com a mãe e as irmãs. Para preservarem a horda, os irmãos se viram forçados a renunciar a esse desejo inicial, que constitui um interdito simbólico, ou seja, os dois tabus fundamentais para a vida familiar: o parricídio e o incesto. Esses dois tabus representam os dois desejos reprimidos no complexo de Édipo.

Segundo Freud (1913-1914), as pulsões de autoconservação é que viabilizam a união dos homens, e não as pulsões sexuais. Sendo assim, esses povos primitivos são o exemplo da imperativa necessidade de encontrar alguma forma de barrar os desejos sexuais, visando à preservação da espécie e, portanto, das organizações sociais. Como moral da história, esse mito ilustra a transição entre um estado originário de interação social, no qual "a obediência era imposta de fora, pela coerção física do pai, para uma forma de obediência baseada na internalização das regras" (BRUNNER, 2000, p. 84), criando o simbólico, a cultura. A angústia da castração, para a psicanálise, é o efeito do processo simbólico da interdição, uma vez que é internalizada a proibição de realizar o desejo incestuoso para com a mãe. Ou seja, de permanecer na relação dual narcísica.

Contextualizamos o interdito do incesto por se tratar de um dos elementos principais de toda trama familiar, constituindo uma questão primordial na organização da parentalidade e da filiação, processos psíquicos que serão ainda discutidos. Os pais precisam ocupar o lugar de portadores da lei que interdita, possibilitando ao filho vivenciar a experiência de perda da onipotência, humanizando-o. Denomina-se humanização o processo de inserir o filho dentro das leis da cultura, capacitando-o psiquicamente a viver em sociedade.

A criança é o elemento que inaugura a tríade, representando a parte excluída, que não participará da cena conjugal. Isso significa que, para convivermos em sociedade, algo precisa ficar de fora. A criança sonha ter a completude do amor de sua mãe e de seu pai. Paradoxalmente, ter esse amor 
deverá protegê-los de sua hostilidade. Para isso, a criança deverá renunciar à satisfação pulsional e admitir a assimetria de seu lugar na cadeia geracional, aceitando, consequentemente, os limites que a cultura lhe impõe e tornando-se um ser socializado (SOLIS-PONTON, 2004).

Portanto, a construção do sistema de parentesco possui a renúncia como regra estruturante. O incesto, como transgressão possível da regra, introduz o tabu, mas também o desejo como realização simbólica do prazer interditado (SOLIS-PONTON, 2004, p. 35). Tornar-se pai ou mãe remete ao reconhecimento de fantasias originais, ou seja, as próprias emoções agressivas e sexuais. "Essas pulsões recalcadas são, entretanto, a parte central de um saber inconsciente das leis primordiais que todo pai e toda mãe devem levar em conta quando tratam de assumir seu papel parental" (SOLIS-PONTON, 2004, p. 36).

Constatamos que os interditos, assim como as regras, constituem as representações de parentesco no nível psíquico e estruturam as bases da organização social. Negar as fantasias inconscientes pode levar a situações paradoxais nas famílias. Como já mencionado, a instituição genealógica tem a função de apresentar ao sujeito o interdito do incesto. Conforme bem descreve Eiguer (2012), o descendente não pode fazer sexo com seu ascendente, e também deve se recusar a matar um ser muito parecido com ele, pois simbolicamente seria como fazer sexo consigo mesmo, ou matar a si próprio.

Compete à mãe e ao pai interditar a condição de se viver sob a égide do narcisismo. Reportando-se ao mito de Narciso e às conceituações freudianas, Legendre (1985) sustenta que a fixação do sujeito na imagem de si mesmo deve ser proibida, cabendo à função paterna a retirada dessa fixação. Para entender a condição narcísica e a influência desta na execução de funções e de papéis na cadeia genealógica, é importante tomarmos como base as formulações de Freud (1914, 1921) sobre o conceito do narcisismo, assim como a compreensão de Legendre $(1985,1990,1992)$ sobre o desenvolvimento psíquico de um sujeito entrelaçado à estrutura psíquica de sua família.

Em uma explicação simplificada, podemos considerar o narcisismo como o processo correspondente ao investimento libidinal do sujeito no ego. No período inicial da vida de um bebê, durante o qual não há distinção entre o eu e o mundo externo, os investimentos libidinais da dupla mãe e bebê são direcionados para o corpo deste. Logo, nesse primeiro momento, o modo de satisfação do bebê é o 
autoerotismo, caracterizado pela satisfação das pulsões parciais nas zonas erógenas, não havendo ainda uma unidade de ego. Uma nova ação psíquica ocorre para complementar o autoerotismo e efetivar a integração do ego. Essa nova ação psíquica é a identificação, que, conforme já descrito, se configura como o processo pelo qual o bebê se vê através do olhar da mãe. De acordo com Legendre (1985, 1992), a constituição de uma linha genealógica - com suas nuances hierárquicas - depende da quebra da imagem da mãe absoluta, pois o desejo do incesto é o amor a este semelhante que reflete a imagem de si mesmo, na qual se quer mergulhar para alcançar a plenitude.

Em relação ao amor incestuoso, é possível pensá-lo como um desejo de o sujeito abraçar a própria imagem a fim de resgatar o único momento em que ele pôde ser amado incondicionalmente (LEGENDRE, 1985). Como mencionado, o sujeito se reconhece pelo olhar materno, ele é através da mãe, percebendo o objeto como sendo ele mesmo. O desejo primitivo é resgatar o único momento no qual ele pôde ser tudo, ser dois em um; portanto, ser o eu ideal. Por isso é preciso que o interdito do incesto seja estabelecido, o que significa, dentro dessa perspectiva, interditar o desejo do absoluto, da completude, de modo a permitir a vivência grupal. Legendre (1985) ressalta que é esta imagem narcísica, na qual não há nem o sujeito nem o outro semelhante, que nutre o desejo incestuoso.

A função paterna é o lugar do terceiro que impõe restrições à relação simbiótica entre a mãe e o bebê. Por consequência, é colocado um limite à ilusão de completude. Assim sendo, por meio da função do terceiro são instalados artifícios simbólicos para capacitar a diferenciação, dando origem ao amor objetal. Conforme Legendre (1985) enuncia, para ser dois é preciso, paradoxalmente, que sejam três. Ou melhor, para haver diferenciação e reconhecimento do semelhante, é necessário que um terceiro entre na relação dual simbiótica. A capacidade de diferenciação é a possibilidade de perceber-se como separado, com a sua própria subjetividade. Portanto, para ser um sujeito individualizado é preciso que um terceiro (a lei, o pai) interrompa a vivência de satisfação experimentada na simbiose.

Para isso, a representação da mãe como diferente do bebê exige uma elaboração, que é construída como uma imagem simbólica. Essa elaboração corresponde a uma desidentificação, significando que a imagem do bebê é descolada da imagem materna. Nesse momento, faz-se necessária a entrada do 
regime jurídico, não somente para organizar as práticas de educação e de criação na cadeia genealógica, mas também para instituir o reconhecimento de imagens distintas.

No entanto, para Freud (1914), o sujeito dificilmente renunciará à satisfação incondicional que ele acredita ter vivenciado, na qual ele próprio era um ideal. Por isso, procura recuperar essa completude narcísica sob uma nova forma de satisfação, que será determinada pela montagem de um ideal de eu. Esse ideal de eu corresponde ao modelo de representações a que o sujeito procura adequar o seu ego. Segundo Freud (1921), esse conceito de ideal de eu é herdeiro do narcisismo, sendo influenciado pelas exigências dos discursos familiar e social, que se tornam representações do próprio ego.

O investimento libidinal dos pais em relação ao bebê tem como núcleo a reprodução de seu próprio narcisismo, transformado em amor objetal, constituindo uma tentativa de alcançar o ideal do eu. O destino do filho é marcado por uma dívida para com os pais, que deve ser paga satisfazendo os sonhos e desejos deles não concretizados. A criança torna-se um meio não só de os pais realizarem esses sonhos e desejos, mas também de dar apoio ao desejo de imortalidade do ego subjugado à realidade da finitude.

Consequentemente, o narcisismo do filho tem origem no narcisismo dos pais e se forma sob esta influência. O risco de ser o depositário do narcisismo dos pais é ser alguém que tem potencial para concretizar desejos e, ao mesmo tempo, é capaz de criar uma ferida narcísica nos pais, caso não os realize. Dependendo da idealização grupal, a singularidade do filho pode ser minada, de modo que seja suprimida a sensação de ameaça à identidade familiar.

Freud (1921) afirma que, para ocorrer formação grupal, é preciso que seus componentes se comportem como se fossem iguais, tolerando as particularidades de cada um, devido à ligação libidinal. Essa ligação seria o único fator que limitaria o narcisismo, uma vez que só o amor objetal poderia ser uma barreira para o amor por si mesmo. Contudo, esse amor objetal só se mantém, caso exerça a função de retornar, em alguma medida, ao ego.

Nesse mesmo texto, Freud (1921) faz alusão à conhecida analogia aos porcos-espinhos para entender as relações emocionais entre os componentes de um grupo. Da mesma maneira que esses animais criam um espaço intermediário, no qual é possível suportar os espinhos e aproveitar o calor de seus corpos, os 
sujeitos também vivenciam essa busca de uma distância ótima, inerente às relações.

Entendemos que nas relações entre pais e filhos é preciso criar um espaço que possibilite a aproximação (semelhança) e o distanciamento (diferenciação). Com isso, a ambivalência seria um componente significativo dessas relações, considerando que haveria a presença de sentimentos hostis à diferença e amorosos à semelhança. Portanto, a ambivalência está presente nas relações como um componente inerente aos processos subjetivos e por isso é relevante elaborá-la nas relações familiares. Os laços afetivos, ao sobreviverem a esses sentimentos ambivalentes, estariam aptos a suportar as diferenças, sem deixar que a identidade grupal entre em colapso.

Fazendo uma articulação entre os desenvolvimentos intrapsíquico e interpsíquico, Legendre $(1985,1990,1992)$ considera importante que o sujeito atinja a diferenciação, o que permitirá a posse de sua identidade. Para tal, é preciso que o semelhante, no caso os pais, também tenham elaborado o limite de seu desejo do absoluto, não concebendo a procriação de um filho como uma reprodução de si mesmo.

Tendo em vista essas assertivas, concebemos que o percurso do desenvolvimento intrapsíquico do sujeito tem sua origem inseparável do seu contexto psíquico familiar. No psiquismo do sujeito existem conteúdos que transcendem a sua individualidade, pois estão presos ao jogo representacional subjetivo e intersubjetivo de seus familiares. Portanto, os processos identificatórios não podem ser compreendidos sem referência à linhagem genealógica.

Freud, em seu texto de 1914, escreveu uma passagem que sugere essa possível leitura:

O indivíduo leva de fato uma dupla existência: uma em que persegue seus próprios fins e outra em que é um elo de uma corrente, à qual serve involuntariamente e, às vezes, até contra sua vontade. Ele imagina que a sexualidade seja uma de suas metas pessoais, mas de outro ponto de vista, podemos considerar o indivíduo como apenas um apêndice de seu próprio plasma germinal, plasma a cuja disposição ele coloca suas energias em troca de um prêmio de prazer. Ele é veículo mortal de uma substância, talvez imortal, em uma posição análoga à do filho primogênito que, ao herdar do pai uma propriedade inalienável, se torna apenas o proprietário temporário dentro de uma instituição jurídica, a herança por primogenitura, que continua a sobreviver a ele de geração a geração. (FREUD, 1914/2004, p. 101) 
Consideramos que, nesse trecho, Freud ratifica sua concepção sobre a existência de um conflito inerente à vida psíquica. Uma das facetas desse conflito seria a necessidade de o sujeito perseguir seus próprios fins, seus desejos, mas limitá-los para viabilizar um elo com seus semelhantes, com a linhagem geracional. O sujeito, como um veículo em sua finitude, apenas herdaria a história familiar para transmiti-la a seus descendentes. A substância do plasma germinal pode ser pensada como o nome familiar, o símbolo de todo o legado a ser transmitido de geração em geração.

A intenção de descrever o narcisismo e o interdito do incesto baseou-se no entendimento de que são condições estruturantes dos processos psíquicos da parentalidade e da filiação, os quais serão discutidos a seguir. É a partir do desenlace de sua própria imagem que o sujeito pode se diferenciar e se instituir na cultura, para posteriormente poder transmitir o legado às gerações que se seguirem.

De acordo com Trindade-Salavert (2010), a família precisa elaborar a perda da onipotência, para que não se identifique maciçamente com um modelo de família extremamente idealizado, como, por exemplo, a Sagrada Família. Segundo a autora, um dos efeitos desse modelo ideal seria o desenvolvimento de um ódio direcionado às futuras gerações, pois elas representariam o novo que demarca a diferença com o que já está estabelecido como o ideal.

\section{3}

\section{Filiação e parentalidade: o devir a ser na cadeia geracional}

A entrada na vida ocorre a partir da reprodução de um "ser" nascido de dois sujeitos com histórias singulares. $\mathrm{Na}$ (re)produção desse "ser" estão presentes dois canais de transmissão determinantes para a continuidade da espécie: o biológico e o simbólico. Mesmo o embrião, representante da combinação genética entre dois seres distintos, está envolvido em um jogo simbólico que será estruturante no processo de subjetivação deste ser humano em devir. As relações de parentesco consolidam o espaço no qual são estabelecidos os primeiros vínculos afetivos e jurídicos, propiciando que o sujeito desenvolva laços de afiliação e de pertencimento. Esses laços servem como base para as demais relações sociais ao longo da vida. 
Conforme destaca Solis-Ponton (2004) e Houzel (2004), o parentesco e a cultura são as organizações fundadoras do ser humano, constituindo o contexto de sua história e de sua genealogia. No Inconsciente, não existe o parentesco como conceito, pois essa noção seria construída na intersubjetividade e por meio da transmissão geracional. Segundo Gutton (2006), as estruturas de parentesco se dividem em diferentes níveis, tais como a família nuclear, a rede familiar extensa e a rede social, diferenciando-se pelos vínculos de consanguinidade e de aliança. O autor também enfatiza o atravessamento de conteúdos conscientes e inconscientes nesses dois tipos de vínculos, formando a singularidade de cada cultura familiar. Gutton (2006) alinha-se à mesma perspectiva de Legendre ao afirmar que as funções genealógicas são simbolizadas e encarnadas segundo as representações conscientes e inconscientes de cada família.

Portanto, o jogo simbólico e os vínculos afetivos familiares legitimam o lugar deste no novo "ser" na cadeia geracional. O recém-chegado é envolvido por um discurso que delineará as inscrições psíquicas em sua subjetividade. Essas inscrições são configuradas na vivência de dois processos interdependentes e simultâneos: a parentalidade e a filiação.

Esses dois processos psíquicos evidenciam a construção mítica familiar, determinando o tipo de arranjo dos vínculos (GUTTON, 2006). É importante enfatizar que a parentalidade não pode ser pensada sem a filiação, porque para ser pai é preciso existir o filho. Sendo assim, só é possível conceber a parentalidade e a filiação a partir de uma relação dialética. Contudo, para fins didáticos, é necessário separar esses dois processos, para distingui-los em suas especificidades.

Parentalidade é entendida como uma reorganização mental que os pais vivenciam e que tem início com a realização do desejo de ter um filho. O sujeito/pai estava anteriormente na posição de filho, tendo uma imagem de si mesmo unicamente como filho de seu pai (LEGENDRE, 1990). Portanto, parentalidade diz respeito aos vínculos de parentesco e aos processos psíquicos que se desenvolvem a partir do desejo de ter um filho.

Antes de aprofundarmos a concepção de parentalidade, cabe tratar do uso deste vocábulo. Conforme o estudo de Bydlowski (2006), o vocábulo parentalidade é um neologismo originado de outro: a maternalidade. Este último termo foi introduzido por Racamier em 1961, para indicar o conjunto de processos 
psíquicos específicos da mulher nos períodos entre a gestação e depois do nascimento do bebê. Essa terminologia, por sua vez, é inspirada no conceito de preocupação materna primária, de Winnicott.

Bydlowski (2006) adverte que o uso do neologismo parentalidade não se aplica à patologia. Essa observação se deve ao fato de que o termo surgiu no contexto da clínica focada nos cuidados da primeira infância, e tal contexto por vezes induz à psicopatologia. Desse modo, o autor visa a salientar que a noção de parentalidade não tem relação com uma linguagem psicopatológica.

O conceito de parentalidade é usado para designar o trabalho de produção psíquica de conteúdos, conscientes e inconscientes, concernentes às experiências de ser pai e de ser mãe. Implica a atividade de simbolização das funções materna e paterna, e diz respeito à impossibilidade de tais funções serem reduzidas ao campo biológico e social (GUTTON, 2006; LEGENDRE, 1985; BYDLOWSKI, 2010). Portanto, a concepção de parentalidade corresponde a um trabalho do psiquismo, como "um tipo de estrutura que se instala em ação e evolui com o desenvolvimento do indivíduo e a evolução do grupo familiar" (SOLISPONTON, 2004, p. 29).

Entre os conteúdos que devem ser simbolizados, Gutton (2006) inclui as representações de condutas normativas, estabelecidas no contexto histórico particular de cada família. Essas condutas servirão de balizas para as funções de criar, cuidar, educar, capacitando os pais a exercerem seus direitos, bem como os deveres de autoridade e de interdição do incesto. Sendo assim, a parentalidade caracteriza-se por ser o processo psíquico de uma nova vivência do sujeito, demarcando as mudanças psíquicas do vir a ser pai e ser mãe (le devenir parent).

Houzel (2004) destaca três funções adquiridas pelos pais que configuram a parentalidade. $\mathrm{O}$ autor defende esse desmembramento para que estejam sempre ressaltadas as várias dimensões da função parental. Uma delas seria o exercício da parentalidade, entendido num sentido próximo ao discurso jurídico, consistindo em um conjunto de regras estruturadas por direitos e por deveres adquiridos pelos pais. Esta função estaria relacionada à questão dos interditos, os quais, como já mencionado, organizam o funcionamento psíquico de todo sujeito. A outra função corresponderia à experiência da parentalidade, representando o nível subjetivo nessa transição de vir a ser pai e ser mãe. Por fim, existiria a dimensão da prática, 
sendo equivalente à atitude de se preocupar com os cuidados e com o bem-estar da criança, presentes nas tarefas cotidianas.

Portanto, na experiência de vir a ser pai/mãe, entendemos que esses sujeitos devem mudar sua inscrição no contexto familiar. De acordo com Legendre (1985), cria-se uma lacuna na subjetividade da família para incluir os novos reposicionamentos geracionais. Essa lacuna será preenchida a partir da permutação simbólica, conceito desenvolvido por Legendre, que corresponde à transformação simbólica, no sujeito, de sua posição na ordem genealógica.

Conforme definido por esse autor (1985), a conceituação permutation symbolique des places supõe um jogo entre três gerações. Assim, para garantir a condição de filho, pertencente à terceira geração, é necessário que a segunda geração renuncie a este lugar e se diferencie da primeira geração. Isso exige que os membros familiares reconheçam uns aos outros em suas novas funções.

Essa formulação de Legendre se torna fundamental, visto que seria a partir dessa permutação simbólica de lugares que se instalaria a função da assimetria na constituição familiar. O jogo entre três gerações instala a assimetria, e com isso a heterogeneidade. Solis-Ponton (2004) afirma que a heterogeneidade permite a complexidade como elemento organizador das relações entre os membros da família. Segundo a autora, como há uma interiorização da assimetria, tanto de lugares quanto de funções, em cada membro da cadeia geracional, é possível constituir um quadro das representações de mundo e de si em relação ao ambiente. Ou seja, a parentalidade organiza o pensamento dos pais diante de si e de seu filho, organizando, consequentemente, o pensamento da criança, que aprende que avós, pais e filhos não são a mesma coisa.

Em consonância com as formulações de Legendre, entendemos que o nascimento de uma criança promove um pacto de aliança e de renúncias entre o filho, o pai e o pai do pai. Remetendo-se ao paradoxo de que para se ter uma identidade individualizada há necessidade de três sujeitos, também para se ter um lugar na cadeia geracional é preciso que existam três gerações no processo.

O sociólogo francês Singly (1993/2007) destaca que os membros familiares podem ser eles mesmos, devido ao olhar dos membros do grupo entre si. A família seria, portanto, esse espaço que promove o olhar mútuo. Há uma interdependência entre os membros do conjunto familiar, e é pela mediação de um outro que o sujeito poderá ter a sensação de ser ele mesmo. Assim, 
simultaneamente mãe/pai e filho configuram seus lugares, legitimando e recriando mutuamente suas funções na família.

O período de gravidez permite à mulher se preparar para a função de mãe, mas somente após o nascimento do filho ela poderá exercer sua maternagem. $\mathrm{O}$ bebê confirma para a mulher sua posição de mãe, demandando e mostrando o quanto ela é vital para seu desenvolvimento. O bebê, em sua dependência absoluta, descrita por Winnicott (1983), necessita estabelecer uma reciprocidade com a mãe, que deverá se adaptar às necessidades dele.

O estado de imaturidade, inerente a todo recém-nascido, exige cuidados permanentes de outro semelhante, do qual o bebê se torna totalmente dependente para superar a condição humana inicial de inacabado. É essa incompletude que promove a construção das representações mentais da ordem da parentalidade e da filiação. Concomitantemente aos cuidados dispensados ao bebê, os pais transmitem a vida psíquica. Tudo isso remete à interdependência dos processos de maturação da criança e da vida psíquica da mãe, vinculada aos cuidados que esta dedica ao filho (SOLIS-PONTON, 2004).

De acordo com Lebovici (1993), o bebê faz seus pais, construindo e parentalizando-os ao mesmo tempo em que ele mesmo é constituído pelos pais. O bebê os parentaliza, por exemplo, quando reconhece a voz da mãe e do pai, seus rostos, distinguindo-os de outros semelhantes e concedendo-lhes sua atenção e olhar quando chamado. Essas competências do bebê gratificam o narcisismo de seus pais, proporcionando a internalização de reconhecimento de suas funções específicas.

Logo, o processo da parentalidade não é simples, pois demarca, de alguma forma, uma crise no psiquismo, uma quebra, com a introdução de uma nova identidade. Talvez não seja adequado falar no envolvimento de uma psicopatologia, como bem ressaltou Bydlowski (2006). Todavia, pensamos ser importante reconhecer a presença de uma vulnerabilidade psíquica transitória, inerente ao processo de permutação simbólica, que por vezes pode levar a caminhos psicopatológicos no devir da parentalidade.

Segundo Bydlowski (2006), para ter acesso à parentalidade, é necessário que se instale uma crise interior silenciosa. Como essa crise se desenvolve de maneira diferente no homem e na mulher, a autora sugere a ideia de crise parental feminina maternal e crise parental masculina paternal. 
Tanto o homem quanto a mulher acalentam o desejo de ter um filho sustentado pelo investimento libidinal de prolongar a espécie e de iludir-se com uma negação da realidade da finitude. Esse desejo de gerar uma criança é formado por um conjunto de desejos infantis, por parte de cada membro do casal parental. Dentro dessa perspectiva (GUTTON, 2006; BYDLOWSKI, 2006), a realização de ter um filho se apresenta como uma alternativa para se trabalhar o luto das imagos parentais recalcadas.

Na proposição de Bydlowski (2006), o retorno do desejo recalcado se difere no feminino e no masculino. O desejo da mulher envolveria a combinação de três elementos pulsionais. O primeiro é a identificação com a mãe confiável do início da vida, a pulsão à maternidade busca encontrar o amor por essa imago primitiva. Essa mãe dos primórdios representa a fonte de vida e de afeto, sem a qual o bebê não poderia sobreviver. O segundo elemento corresponde a um desejo edipiano, o de receber um filho como presente do pai, atualizando-se o amor edipiano. Por fim, o terceiro elemento consistiria no encontro do amor sexual relacionado ao homem atual, o qual encarna a combinação dos dois primeiros amores descritos.

Dentro da problemática masculina se destacam dois movimentos: a possibilidade de negar o desejo de ter um filho e a identificação com o feminino. A paternidade surge como uma oportunidade para se identificar com o pai idealizado, mas também com sua própria bissexualidade, ao reconhecer em si uma parte feminina que compõe seu ego. Quanto à negação do desejo de ter um filho, esta é derivada da impossibilidade biológica de gerar o bebê. Como este nasce em um corpo separado do pai, a sensação de imortalidade, representada pela produção do filho, fica postergada para o homem. Este, mesmo que considere o bebê uma parte dele, só vai viver isso após o nascimento (BYDLOWSKI, 2006; LEGENDRE, 1990).

Os homens que negam o próprio desejo assumem uma distância psíquica do bebê, reconhecendo que o desejo de ter um filho é apenas da mulher. Como sintoma disso, eles se afastam da mulher no período de gravidez e investem em objetos fora de casa. Por exemplo, começam a se dedicar a eventos sociais, intelectuais, amorosos, entre outros. Ao fazer isso, eles contribuem para a sua própria exclusão (BYDLOWSKI, 2006).

Bydlowski (2006) observa que o elemento comum a ambos, pai e mãe, é a exigência de um trabalho psíquico na transição da gestação para o bebê real. A 
barriga desperta fantasias, pois é portadora de mistérios, e a sua transmutação para um rosto desconhecido, e distinto do imaginado, configura a ambiguidade do momento do nascimento (mágico e aterrorizante).

Além de se defrontarem com o desconhecido bebê, os pais, como já mencionado, também passam a ocupar um lugar desconhecido na cadeia geracional. Para ocuparem essa posição, precisam renunciar à exclusividade do lugar de filho, mediante a desidealização de seus próprios pais, para que estes os autorizem a assumir a parentalidade.

Após o nascimento, devido à idealização, os pais olharão para seu recémnascido como se ele fosse imaculado. E, por um período de tempo, em decorrência da fragilidade psíquica, o bebê será depositário da projeção de representações pertencentes à história pessoal de seus pais. Assim, se inicia o processo de filiação entrelaçado à instalação da parentalidade.

Nos casos em que ocorre uma falha na instalação da parentalidade, é a própria idealização de seus pais que impossibilita se sentirem à altura da imago dos mesmos. Outra possibilidade de falha é a invasão, nos novos pais, de imagens conflituosas e agressivas sobre eles mesmos como bebês, projetando essas representações no filho real. Este será percebido como uma ameaça, por encarnar o bebê internalizado de seus pais, e isso desencadeará ansiedades persecutórias na constituição da relação parental (BYDLOWSKI, 2006).

O casal em crise pode também ser um solo fértil para a ocorrência de disfunções relacionais. Após o nascimento do bebê, o casal deverá suportar o declínio da realização de suas necessidades narcísicas, pois, neste período inicial, o que está em primeiro plano é a sujeição à parentalidade (BYDLOWSKI, 2006).

Do ponto de vista de Lévy-Soussan (2006), o trabalho psíquico próprio da filiação envolve fortemente a problemática do narcisismo parental. Ainda segundo o autor, uma das condições para a filiação ser bem sucedida é os pais serem capazes de fazer o filho se apropriar da história familiar de cada um dos dois e, ao mesmo tempo, permitir que ele possa construir a sua própria identidade. Essa construção ocorre quando é possível ao filho elaborar as duas histórias parentais, juntamente com a sua própria história.

Dentro dessa perspectiva, Trindade-Salavert (2010) destaca a impossibilidade de se considerar a construção da individualidade como algo separado da relação com o outro e com seus ancestrais. Para ser pai e mãe é 
preciso um filho que dê vida e sustente a potencialidade parental. Por outro lado, este filho também precisa ser inserido e reconhecido, para consolidar sua história na família.

Como já foi comentado, as noções sobre os processos de parentalidade e de filiação são exemplos de construções psíquicas que possuem como condição a mutualidade e o paradoxo. Ou seja, elas dependem da presença de uma reciprocidade na experiência de ser entre pais e filhos. Sendo assim, o processo de filiação corresponde ao efeito de todas essas mudanças psíquicas parentais. Esse processo depende, efetivamente, da capacidade dos pais de representar e elaborar suas questões infantis, para poderem transmutar simbolicamente o eixo genealógico e, assim, incluir o recém-chegado como filho.

Autores como Trindade-Salavert (2010), Levy (2009), Zornig (2009) e Passos (2005) apontam a necessidade de o bebê ser inserido em uma cadeia geracional de filiação, devendo ser reconhecido pelos pais como filho. Atribui-se o fato de o sujeito ser filho de alguém não a um fator genético, mas à sua inclusão em uma linhagem genealógica. Essa inclusão faz com que este novo integrante seja denominado "filho de", recebendo um sobrenome, que é a parte de sua identidade relacionada à sua ascendência. Logo, esse processo de inscrição no laço de parentesco é que une o novo sujeito às gerações, e se denomina filiação.

Trindade-Salavert (2010) e Lévy-Soussan (2006) defendem a importância da concepção de Legendre $(1990,1992)$ de que a filiação é sustentada por três pilares: o biológico, o jurídico e o inconsciente. Refletindo sobre essa concepção, consideramos que a filiação é resultante do entrelaçamento desses pilares, uma vez que cada um deles representa valores simbólicos específicos, que estruturam a constituição da filiação. Eles são representantes de três níveis diferentes de verdades que se relacionam entre si, mas que não devem ser confundidas. Tais pilares, implicados indissociavelmente na composição do processo de filiação, representam a especificidade humana como ser do campo da biologia, da linguagem e da alteridade procedente dos investimentos objetais.

Trindade-Salavert (2010) denomina esses três pilares como o eixo da filiação biológica, o eixo da filiação jurídica e o eixo da filiação afetivoimaginária. Já Lévy-Soussan (2006), diferentemente, denominou o terceiro eixo de filiação psíquica. Contudo, há uma abrangência nesta última denominação, tendo em vista que o trabalho de constituição da filiação já é, em si, um trabalho 
psíquico. Neste trabalho adotaremos a denominação proposta por TrindadeSalavert (2010).

O eixo da filiação biológica corresponde à procriação decorrente da intervenção de produtos genéticos de sexos opostos que resultam em uma criança. Esse eixo oferece ao sujeito o pertencimento a uma descendência biológica, fazendo-o herdeiro de uma transmissão genética. De acordo com TrindadeSalavert (2010), esse eixo por vezes torna-se depositário de projeções e fantasias narcísicas parentais na busca de uma garantia de igualdade e de recusa ao diferente em relação aos filhos. Portanto, o biológico às vezes é um componente fortemente idealizado pelo social. Contudo, o fator biológico é incapaz, por si só, de fundar a filiação. Ele não é responsável pela origem do desejo de ser pai/mãe e pela transição subjetiva do tornar-se pai/mãe.

O eixo da filiação jurídica pertence ao âmbito legislativo, que define as regras e as leis para o estabelecimento das condições de filiação, produzindo efeitos simbólicos de ordem social na constituição da família. É uma via com o poder de fundar a filiação, de criar e reconhecer a identidade genealógica (LEGENDRE, 1992). A instituição jurídica determina a realidade do laço familiar, permitindo a legalização e, portanto, a legitimação social do vínculo afetivo. Devido a isso, a tradição jurídica ocidental tem sido fundamental no reconhecimento da paternidade e dos rearranjos familiares não biológicos.

O eixo da filiação afetivo-imaginária corresponde ao investimento afetivo parental, que possibilita uma disponibilidade subjetiva para que os sujeitos se considerem pai e mãe daquele ser (filho ou filha). Esse eixo está desconectado da genitalidade, sua base são as representações ligadas à lógica do consciente e do inconsciente, produzindo uma solidez subjetiva que permite assegurar um vínculo de filiação. Portanto, é criador da ficção filiativa, sendo esta o discurso que propicia aos pais e aos filhos a elaboração simbólica de um nascimento originado do desejo parental, ou seja, da fantasmática parental que precede o nascimento (LÉVY-SOUSSAN, 2006). Enfatizamos que a filiação afetivo-imaginária se constitui com o tempo, a partir das interações psíquicas entre pais e filhos.

Trindade-Salavert (2010) afirma que, para a filiação ter o reconhecimento social e estabelecer os vínculos, estes dois eixos bastam: o da filiação afetivoimaginária (indispensável para constituir, no plano psíquico, o parentesco) e o da filiação jurídica (que nomeia o pai). A respeito da filiação biológica, ela não é 
apontada como uma garantia do senso de parentalidade, apesar de ser intensamente idealizada pela sociedade.

Após todas essas colocações, pensamos que o processo de filiação está diretamente ligado à capacidade psíquica de os pais lidarem com perdas (principalmente as que dizem respeito ao seu lugar de filho na família) e ganhos (novas funções). A metabolização, de cada um dos pais, sobre sua própria história e seus conteúdos psíquicos incitará a potencialidade do filho de se apropriar de sua história, podendo transformá-la da melhor maneira possível. Vale ressaltar a importância deste jogo mútuo de transmissão de conteúdos psíquicos e afetos, dos quais o sujeito deverá se apoderar e transformar. Tudo isso determinará o lugar designado ao filho e como este o assumirá na cadeia geracional.

A partir dessas considerações, podemos afirmar que o processo de filiação tem como eixo subjetivo o tipo de relação entre as gerações, ou seja, como os membros familiares se reconhecem e dão lugar às diferenças, estruturando seus mitos. Caso na família haja um intenso investimento narcísico, possivelmente, predominará nas relações afetivas a indiferenciação entre os membros do grupo. Isso pode fragilizar a saúde emocional do grupo todo, colocando a separação como uma ameaça à identidade familiar. Nestes casos, a diferenciação é vivenciada como uma catástrofe, pois, do ponto de vista psicanalítico, a família se organizaria sob as bases de uma idealização, que poderia ser perdida.

Pensar a família como um espaço estruturado pelo paradoxo, no qual coexistem a união e a separação, a transmissão e a criação, a identificação e a individuação, é reconhecer a complexidade da experiência de ser uma família. Essa experiência é constituída por uma dinâmica singular, tecida pelo intercâmbio de conteúdos psíquicos conscientes e inconscientes de todos os membros do grupo. 


\section{3. ADOÇÃo E OS POSSÍVEIS DESDOBRAMENTOS NA TRAMA FAMILIAR}

A adoção vem se apresentando como tema em evidência na contemporaneidade, envolvendo as mais variadas representações sociais. Esse fenômeno tem sido abordado com certa frequência em reportagens jornalísticas, em capas de revistas e em discussões na internet. Isso porque é cada vez maior a aceitação social da legitimidade da filiação afetiva, antes considerada um desvio à normalidade da filiação biológica (SCHETTINI, AMAZONAS e DIAS, 2006). Devido às mudanças da mentalidade social e ao interesse científico sobre o tema, hoje em dia a adoção tem um lugar expressivo entre as alternativas de realização do desejo de ter um filho.

No estudo realizado por Gomes e Monaco (2005) sobre a configuração de famílias adotivas no Brasil, é feito um breve histórico sobre a concepção da adoção, dentro de uma perspectiva jurídico-social. Eles constataram que na época patriarcal apenas os filhos biológicos, gerados na relação estabelecida pelo matrimônio, eram reconhecidos como legítimos e protegidos pelas leis do Estado. Os filhos de casais que viviam juntos sem o reconhecimento legal eram nomeados de ilegítimos naturais. Os ilegítimos espúrios eram os filhos gerados em situações de adultério, de incesto e de sacrilégio (filhos de padres ou freiras ligados à hierarquia da Igreja Católica). Esses valores, denominações e concepções legais prevaleceram juridicamente na Constituição até 1988. Nesse ano, modificou-se a visão jurídica sobre a configuração familiar, legitimando o casamento por união estável e as famílias monoparentais.

Ainda segundo o estudo de Gomes e Monaco (2005), no Código de 1916, por influência de Portugal, passou-se a reconhecer a adoção simples, a qual assegurava o vínculo parental exclusivo entre o adotado e o adotante. Ou seja, o adotado não adquiria relações de parentesco com o grupo familiar do adotante. Posteriormente, em 1979, criou-se a lei de adoção plena, cuja intenção era estender o laço familiar do adotado aos demais membros da família, a fim de garantir a paridade sucessória em relação aos demais. 
No entanto, foi somente com o advento do Estatuto da Criança e do Adolescente (ECA) que as desigualdades cessaram entre filiação legítima, ilegítima e adotiva, principalmente sob o aspecto patrimonial (FERREIRA, 2010). Esse estatuto reconhece a adoção como uma maneira de minimizar a problemática de abandono. O significativo número de crianças e adolescentes abandonados e negligenciados no país tem incentivado a Vara da Infância e da Juventude a divulgar a prática da adoção como um direito do sujeito de pertencer a uma família. Como consequência desse movimento, foram criadas muitas associações de apoio a candidatos e a pais adotivos (QUEIROZ, 2004). Nos dados colhidos por Ladvocat (2008), consta que "no Rio de Janeiro, existem cerca de 180 pessoas ou casais interessados em adoção", sendo a adoção de bebês brancos a preferência da maioria, razão que explica o baixo índice (23\%) de adoções inter-raciais legais (p. 588).

No dia 15 de julho de 2009, o Senado aprovou uma nova lei de adoção - a Lei n. 12.010/09, considerada um grande passo jurídico para a percepção de problemas subjetivos no percurso que antecede e que sucede a adoção. Segundo Ferreira (2010), a lei consolida uma transformação social, "seja quanto ao conceito de família, como também em relação ao acolhimento de crianças e adolescentes" (p. 11). Ao reconhecer os profundos efeitos desse processo, o Estado passou a proteger o adotado em sua dimensão subjetiva, procurando garantir juridicamente o senso de pertencimento, tão necessário para a construção da identidade.

Entre as alterações introduzidas pela lei em questão, estão novas designações, tais como poder familiar em vez de pátrio poder, abrigo para acolhimento familiar em substituição a acolhimento institucional. Também se definiu família extensa como o desdobramento para além da unidade pais e filhos, incluindo parentes próximos ao convívio afetivo com a criança ou o adolescente. Buscou-se demarcar os direitos à vida, à saúde, à convivência familiar e comunitária e aos laços fraternos, na guarda de grupos de irmãos (FERREIRA, 2010).

Para Silva (2011), com a reformulação da lei, o grande avanço em relação ao panorama anterior foi o estabelecimento do cadastro nacional dos pretendentes, oferecendo a estes uma preparação psicológica e acesso a uma rede informatizada. De acordo com a autora, o objetivo é dar apoio e esclarecer os reais significados 
da adoção e suas particularidades, tornando os grupos de apoio à adoção o dispositivo indispensável para a efetivação dessa preparação.

Como aspecto principal desse movimento jurídico, destacamos a proteção em priorizar os reais cuidados para com a criança e o adolescente, cuja adoção deve estar fundada em motivos legítimos por parte dos adotantes. Não pretendemos descrever minuciosamente a nova Lei da Adoção, por não ser importante para os fins deste trabalho. Contudo, consideramos fundamental esse movimento jurídico, por configurar um avanço no estabelecimento de uma nova cultura no tocante à representação social da adoção. A criação desta lei representa a atenção ao humano e a preservação de sua singularidade, a qual, por vezes, é aniquilada pelas práticas sociais predominantes.

No entanto, ressaltamos que, mesmo com a proteção do Estado e com os direitos assegurados pelo Judiciário, não há garantias de que filhos e pais adotivos não sofrerão nesse processo de parentalidade e de filiação. A construção dos laços afetivos de parentesco depende fundamentalmente da qualidade do encontro intersubjetivo entre os envolvidos. A reportagem da revista Época (2009) descreveu histórias de fracasso na adoção, denominadas de "Lado B da Adoção", compostas por situações de pais que devolveram os filhos sem explicação, após alguns anos de convívio familiar.

Profissionais envolvidos em processos de adoção, como psicólogos, juízes e promotores, são unânimes em afirmar os abalos de identidade nas crianças e adolescentes que são devolvidos. Há o reconhecimento, por esses especialistas, do trauma deflagrado por uma segunda privação afetiva familiar, e como consequência, ações inéditas vêm sendo movidas na justiça. Considerando essas histórias, devemos ter em mente que a adoção não é um processo que se inicia e acaba com os trâmites jurídicos. Pelo contrário, começa desde a fomentação do desejo de ter o filho e a definição da decisão, sem ser possível determinar um ponto final, uma vez que os vínculos afetivos familiares passam por uma contínua transformação no decorrer da vida geracional.

As discussões científicas acerca da adoção são relativamente recentes. Do ponto de vista de Queiroz (2004), ainda parece existir na literatura uma cisão sobre a temática. Para a autora, as formulações teóricas dividem-se em dois posicionamentos antagônicos. O primeiro denuncia e visa abater os preconceitos, buscando desmitificar o valor da filiação biológica e combater a desqualificação 
da filiação adotiva. $\mathrm{O}$ segundo posicionamento enfoca os efeitos traumáticos do processo de adoção, consolidando uma vertente pessimista a respeito dessa filiação.

Neste trabalho, esperamos desenvolver uma compreensão que não seja determinada por essa cisão. Para tanto, procuramos tratar o tema de modo integrado, não só conservando as especificidades implicadas na parentalidade e na filiação adotivas, como também afastando qualquer representação preconceituosa e reducionista da questão. Cabe destacar um aspecto essencial da adoção, que é a singularidade de elementos que compõem essas histórias familiares. Justamente por isso a adoção configura um terreno extremamente complexo e variado quanto aos seus desdobramentos.

\section{1}

\section{Antecedentes da adoção: descontinuidades biológicas e demandas de vínculo}

Para descrever a formação da parentalidade e da filiação adotivas, temos que ter em mente, desde o início, a existência de duas histórias distintas - a dos pais e a da criança/adolescente -, que serão tecidas em uma mesma trama a partir da adoção. Tanto na vivência dos pais como na da criança/adolescente, haverá necessariamente um elemento comum em ambas: a descontinuidade biológica. Independentemente dos motivos, na história de ambos, existirá a marca dessa ausência, a qual acaba compondo um dos elementos originários na constituição desse vínculo.

Rotenberg (2011) considera que, através da adoção, é inaugurada a semente de um vínculo afetivo, que representa concomitantemente uma reparação e uma mudança. Sendo assim, defendemos que a premissa básica na formação da parentalidade e da filiação adotivas é a existência de paradoxos como ruptura e vínculo, luto e investimento libidinal. Para compor o desenvolvimento deste tema é necessário, portanto, fazer um paralelo entre os desdobramentos das possíveis vivências tanto da criança/adolescente como dos pais.

Enfocando primeiramente a história inicial da criança, podemos afirmar que a forma de ruptura do vínculo entre as crianças e seus pais biológicos envolve uma multiplicidade de fatores, como, por exemplo, doação, abandono ou dificuldades insuperáveis. De acordo com Peiter (2011), na realidade brasileira 
são inúmeras as razões de descontinuidade do vínculo com a família de origem, sendo muito difícil descrever sua amplitude, o que favorece a criação de préjulgamentos a tais situações.

O autor ressalta que a decisão de afastar uma criança de sua família de origem é uma questão delicada, sendo os critérios objetivos muitas vezes insuficientes para solucionar os impasses. De acordo com a lei, uma criança será colocada como candidata à adoção quando as possibilidades de reinserção familiar estiverem esgotadas, acarretando a destituição do poder familiar por sentença jurídica. Um grande problema se abre com essa situação, pois, nesses casos, na maioria das vezes, a criança já está crescida e permanece fora dos padrões de interesse dos candidatos nacionais (PEITER, 2011).

Independentemente dos motivos da descontinuidade com a família de origem, há uma separação, uma quebra no circuito geracional da criança/adolescente. Portanto, a atenção para com eles deve ser redobrada. Mas como fazer isso sem rotulá-los e sem lançar mão de pré-concepções moralistas? Tratá-los como "abandonados" faz justiça à realidade de suas experiências ou já carregaria rótulos indissolúveis na identidade?

O termo abandono está geralmente vinculado a uma ideia de rejeição. Conforme afirma Abrão (2011), essa ideia sobre o abandono ocorre porque tal ato promove a ruptura de um elo indissolúvel no imaginário, configurando uma grave ameaça à sobrevivência do indivíduo. De acordo com a autora, a noção de abandono foi construída em três séculos, estando seu significado intimamente ligado aos padrões éticos e morais desenvolvidos a partir do Iluminismo.

$\mathrm{Na}$ época colonial do Brasil, a entrega de um filho permanecia muito associada à miséria, à escravidão ou ao fato de a criança ser fruto de relação ilícita. Naquele período, geralmente quem entregava o filho pertencia às classes sociais desfavorecidas, o que fortaleceu, no imaginário de hoje, o surgimento, por parte da família que realiza a adoção, das fantasias de desvalorização relacionadas à condição social da família de origem. Abrão (2011) destaca que essas fantasias, patrocinadas pela realidade social de uma época, muitas vezes instituem o paradoxo de um desencontro e um encontro entre esses dois mundos imaginários. Ou seja, entre dois grupos distintos, os pais biológicos e os pais adotivos, os pobres e os ricos, os maus e os bons. 
Concordamos que há uma estreita relação entre abandono e rejeição no imaginário social. E foi para evitar os sentidos pejorativos da palavra abandono que se passou a utilizar atualmente o termo privação. $\mathrm{Na}$ história da criança/adolescente que antecede a adoção, necessariamente existe privação. Em última instância, a privação se daria em torno do conhecimento de sua origem, nos casos de entrega de bebês, e da convivência com a cadeia geracional biológica, no caso das crianças tardiamente colocadas para adoção. O buraco imposto por essa ruptura pode acabar sendo uma fonte de intensas projeções. Talvez como uma tela de cinema em branco, na qual pode ser projetada qualquer imagem, preenchendo o vazio da tela com alguma representação.

Peiter (2011) sustenta que os adotivos não podem ser considerados crianças abandonadas, pois, desde a entrega à adoção, ficam em instituições especializadas, sob a proteção do Estado. Para algumas crianças, que sofreram riscos de vida ou foram negligenciadas por seus pais, a vida institucional talvez possa representar acolhimento e segurança. Relembramos, porém, que os efeitos da privação de uma relação familiar significativa e contínua não deixam de existir.

Principalmente nos primórdios da sua vida, o bebê precisa ser adotado para ter condições de sobreviver. Peiter (2011) e Silva (2011) relembram que, por isso, qualquer tipo de filiação passa por uma "adoção", no sentido da vinculação afetiva. Essa condição de desamparo, presente na vida de qualquer ser humano, torna-se muito explícita na história da criança a ser adotada, devido à descontinuidade de sua origem. Essa descontinuidade ocorre geralmente em um período de vida no qual a criança ainda não possui maturidade psíquica para reagir a determinadas situações.

Green (1980) afirma que o desinvestimento materno, em períodos precoces do desenvolvimento psíquico, desencadeia um comprometimento narcísico - um buraco. O bebê precisa que sua onipotência seja mantida inicialmente por sua mãe. Caso isso não ocorra, essa condição desfavorável do ambiente pode levá-lo a grandes ansiedades e a defesas rígidas. A busca de preenchimento para a perda narcísica circunscreverá o tipo de funcionamento mental do sujeito.

$\mathrm{Na}$ verdade, encontros dramáticos na díade mãe e filho podem desencadear sérias ansiedades na criança, mesmo não ocorrendo um abandono de fato, mas apenas uma vivência disso. No desenvolvimento do mecanismo "complexo da mãe morta", Green (1980) descreve que a criança pode fazer uma identificação 
com o vazio objetal. O sujeito identifica-se com o vazio deixado pelo desinvestimento libidinal. Essa concepção de Green nos ajuda a entender possíveis desdobramentos do funcionamento mental, a partir da ausência de investimento materno. Cabe ressaltar a dificuldade de mapear as vicissitudes da vida mental na criança adotada. A descontinuidade dos vínculos familiares de origem certamente terá efeitos diferentes, dependendo da idade da criança, das condições ambientais primitivas em que a mesma viveu e das experiências emocionais vividas nas relações objetais primitivas.

Peiter (2011) pontua que, em alguns casos, a entrega da criança, por parte da genitora, não se deve ao desinvestimento, mas a uma tentativa de salvar a criança por meio da adoção. Em razão disso, a autora repudia o caráter nocivo do discurso de pais adotivos que transmitem a crença de uma "mãe biológica ruim, que rejeita”. Os pais adotivos assumem um papel importantíssimo nessa reconstrução da identidade de seus filhos, sendo fundamental para estes a representação que os pais adotivos dão à sua história de vida, às descontinuidades.

O importante é saber que a descontinuidade e a privação não decorrem, necessariamente, de uma rejeição por parte dos genitores. Contudo, isso não impede de o filho adotivo interpretar como um ato de rejeição. Dentro desta perspectiva, Filho (2009) concorda com a impossibilidade de ser negada a história pregressa da criança a ser adotada. Como os pais possuem um conhecimento parcial dessa história, lançam mão de seus recursos internos na construção de interpretações e julgamentos sobre a mesma.

Filho (2009) menciona que o conhecimento parcial da pré-história da criança é um dos buracos narcísicos nos pais. Este "não saber" sobre a história do filho remete os pais adotivos à parte desconhecida de sua própria história, já que, na história de qualquer sujeito, existem elementos desconhecidos. Entendemos que o autor coloca em questão as fantasias dos pais relacionadas aos buracos de sua própria história, e como estas os influenciam no trato com os buracos dos filhos. "Para algumas pessoas os incômodos provocados pela adoção estão mais voltados para o que é desconhecido do que para o que venham a conhecer durante a criação" (FILHO, 2009, p. 24). Isso vai ao encontro da ideia filosófica de que tememos o que não conhecemos e amamos o conhecido. Justamente porque o desconhecido é a tela em branco do cinema, e por isso grande fonte de ansiedades 
paranoicas, na medida em que as imagens projetadas possam ser aspectos do self insuportáveis de serem contidos internamente.

A adoção, para as crianças, significa ter uma nova história, que ao mesmo tempo em que oferece esperança, demarca perda e separações, principalmente no caso de crianças maiores que passaram por abrigos (PEITER, 2011; FILHO, 2009). Para essas crianças, a espera por adoção é maior em comparação à de bebês de até dois anos de idade. Muitos estudiosos sobre a questão apontam essa realidade (PEITER, 2011; WEBER, 2001), alegando que a preferência por bebês está fortemente correlacionada ao fato de a adoção ser uma solução para problemas de infertilidade.

Em geral, os candidatos a adotar temem se vincular a crianças maiores devido à fantasia de que elas tenham sido influenciadas negativamente por seu ambiente de origem. Weber (2001) apresenta em seu estudo que 76,4\% dos candidatos desejam crianças abaixo de dois anos. Do ponto de vista da criança maior, a nova vinculação afetiva pode ser vivida sob o envoltório de diversas fantasias, entre elas a idealização, o risco da nova vinculação, ou até mesmo a fantasia de traição à família de origem.

Muitos podem questionar se seria possível a nova filiação ser vivida como um risco, pois, afinal, trata-se de um recomeço para a criança. No entanto, conforme postula Filho (2009), o passado para a criança e o adolescente é tão próximo que se confunde com o presente. As dores do presente reativam as dores do passado, sendo estas últimas que oferecem o colorido da dor atual. É importante considerar que as crianças adotadas necessitam de tempo para aceitar a decisão unilateral de sua adoção (FILHO, 2009; ROTENBERG, 2011). Silva (2011) salienta que a criança maior precisa compreender e aceitar a adoção, permitindo-se viver esta situação particularmente complexa na medida em que deverá apreender e assimilar tudo aquilo de que foi privado, tal como a continuidade, a segurança e o senso de pertencimento.

Um fator a ser incluído no encontro para adoção é que a criança possa se sentir escolhendo para se vincular àqueles que pretendem adotá-la. Portanto, falase de um encontro entre adultos e criança, no qual deve advir a mutualidade do desejo de ligar-se afetivamente. No desenrolar da vinculação, o "como se" fossem parentes deve gradualmente migrar para o "ser" parentes, mas o destino desse processo é impossível de ser calculado. 
Dentro da perspectiva dos pais adotivos, a razão manifesta para a escolha da adoção é o desejo de ter um filho. Como em toda decisão por um filho, a adoção exige tempo de reflexão e incorporação da ideia. No entanto, este é um cenário com especificidades. Os pais devem reconhecer como filho a criança gerada por outro. Além disso, eles precisam elaborar os possíveis lutos ligados à impossibilidade de gerarem um filho biológico.

Zornig (2009), em seu estudo sobre a transmissão psíquica e a modificação do aparelho psíquico parental com o nascimento de um filho, faz a distinção, a partir das formulações de Bydlowski, entre o desejo de engravidar e o desejo de ter um filho. A diferença estaria na orientação do investimento libidinal, pois, no primeiro desejo, o investimento estaria direcionado para o processo de gestação e suas implicações, como, por exemplo, o sentimento de completude. Já o desejo de ter um filho envolveria o investimento entrelaçado à perpetuação geracional.

Podemos afirmar que, na adoção, tanto o desejo de completude no processo de gestação quanto o desejo de perpetuação geracional, respaldado no fator biológico, exigem um processo de luto, caso inicialmente estejam impregnados do desejo de ser pai e mãe. Tendo em vista a inviabilidade da realização desses desejos (inconscientes), surge a pergunta: qual a razão de se optar pela adoção para ter um filho?

Entre os desejos imbuídos em uma adoção, talvez possamos incluir a amplitude de questões inconscientes envolvidas no desejo de ter filhos, de ser pai e da atitude de adotar. Tais desejos podem ser compostos por diferentes arranjos representacionais inconscientes, como, por exemplo, o desejo de ter um filho para transmitir os valores familiares, de ser pai a fim de diferenciar-se de seus próprios pais, de adotar/salvar para reparar uma fantasia destrutiva inconsciente.

De fato, o que está sendo apontado é que, em relação às profundezas do inconsciente que alicerçam a demanda de um filho, não existe certeza, e para cada sujeito isso se configura de modo bem singular. No processo de adoção, alguns candidatos podem dispor de espaços para refletirem sobre os desejos envolvidos na parentalidade, mas, para a maior parte da população, isso não ocorre. Em geral, as pessoas "engravidam" e têm filhos de uma forma distanciada dos próprios desejos. Esse distanciamento não fica silencioso, traz efeitos barulhentos ao longo do desenvolvimento dos vínculos de parentalidade e de filiação, podendo ser muitas vezes ensurdecedores. 
Para um profissional atento, portanto, a afirmação "quero ter um filho" pode significar inúmeros sentidos. No campo da parentalidade e da filiação não há certezas e verdades simples, e o estudo da adoção ratifica isso de forma bastante clara. Independentemente de a filiação ser biológica ou ser adotiva, existem dúvidas e conflitos que integram o vínculo parento-filial.

Filho (2008) e Rotenberg (2011) notam que a decisão de adotar implica uma gestação simbólica, e não biológica, e isso permitirá a inserção do filho na trama familiar. O tempo de noves meses de uma gestação é o tempo de preparo dos pais para receber o bebê. À medida que a barriga cresce, é sinalizada a contagem regressiva da chegada de um terceiro na relação conjugal. $\mathrm{O}$ casal adotivo não tem tempo certo, e diante da realidade brasileira, sua espera frequentemente passa dos nove meses, chegando por vezes a durar anos. Segundo os dois autores, a gestação simbólica é um tempo para pensar sobre essa demanda e para elaborar os lutos.

Ducatti (2004) também procura fazer distinção entre simbólico e biológico, ao contrastar gestação e maternidade. A autora explicita que a gestação corresponde a condições fisiológicas, que não asseguram a predisposição psíquica. Já a maternidade englobaria as condições de ordem psíquica, que propiciariam o status de mãe mesmo que um filho não fosse gerado.

Filho (2008) enfatiza que, dependendo do tipo de motivação para se optar pela adoção, a saúde familiar poderá ser comprometida, principalmente em situações nas quais a decisão emerge de uma demanda secundária e circunstancial. O que seria isso? O desejo de ter um filho adotivo fica em um nível secundário, pois o desejo primário seria, por exemplo, a substituição de um filho morto, a negação da ferida narcísica provocada pela infertilidade, ou a consolidação da imagem de bondade (filantropia), entre outras. Segundo Filho (2008), as principais origens motivacionais podem ser localizadas em três campos: o biológico (representado pela infertilidade), o social (representado pelos valores humanitários) e o emocional (representado por um filho morto ou por transmissão familiar).

Trindade-Salavert (2010) observou em sua clínica algumas consequências nocivas de adoções motivadas por valores humanitários. Segundo a autora, muitas vezes a imagem do bebê desamparado fortalece o discurso centrado na crença de que o amor é suficiente. Devemos lembrar que, na relação parental, não existe somente o amor, existem também o ódio e a inveja, ainda que o amor deva 
prevalecer para mitigar estes últimos. Para a autora, o discurso centrado na filantropia pode ocasionar algumas distorções no processo de filiação. A essa afirmação da autora, acrescentamos que a distorção reside na crença da filantropia como algo patrocinado pelo amor. Quando a filantropia não favorece a promoção de saúde, isso pode ser devido à onipotência e ao narcisismo, ideia que desenvolveremos melhor mais adiante.

Outra motivação frequentemente destacada como adversa na literatura é a infertilidade de um dos cônjuges, a qual é apontada como a causa mais comum para a decisão da adoção. Nestes casos, essa decisão resultaria em uma solução para a falha biológica, sendo uma alternativa que facilita o caminho de reparação desta falha e de concretização do desejo de ter um filho (SCHEJTMAN, 1990; LEVINZON, 2000).

Schettini et al. (2006) e Lopes (2008) ressaltam que a impossibilidade biológica de gerar um filho deve ser seguida de um luto e um processo de aceitação da perda do "filho biológico". Há um consenso entre os estudiosos de que, nessas situações, o desejo de adoção deve ser efetivamente trabalhado, a fim de permitir ao casal uma elaboração da ferida narcísica e uma compreensão da dinâmica psíquica conjugal.

Os pais não devem colocar o filho adotivo no lugar do "filho biológico perdido", criando uma situação para o adotado de inexistência psíquica (SCHETTINI et al., 2006; HAMAD, 2001). Cabe destacar que existe também uma singularidade no sofrimento de cada cônjuge, que deve ser escutado individualmente, de acordo com as fantasias e com as questões pessoais.

Um aspecto particular da filiação, sob a égide da infertilidade, assinalado por Schejtman (1990), é o estabelecimento de um encontro entre um casal impossibilitado de conceber um filho e uma criança concebida por outro casal. Como já foi abordado, de um lado há aqueles que vivenciaram a ruptura com a descendência biológica, e do outro aquele sujeito que vivenciou o rompimento com a ascendência biológica. Portanto, entendemos como primordial a possibilidade de os adotantes e de sua família elaborarem as origens da demanda de adoção. Ao simbolizarem suas motivações inconscientes e conscientes, poderão minimizar riscos de falência dos vínculos. A simbolização também permitirá dar um sentido ao lugar que cabe ao adotado na trama geracional e ao lugar que este ocupa na economia psíquica dos pais. 
Dentro dessa perspectiva, Schettini et al. (2006) afirmam que o trabalho psicológico com os candidatos, no período que antecede a adoção, ajuda a flexibilizar as exigências destes com relação às características da criança, atenuando a intensa idealização depositada no provável adotado. Peiter (2011) acrescenta que esse trabalho é necessário, pois com frequência os postulantes não se encontram preparados para a paternidade adotiva, estando até mesmo desinformados sobre as vicissitudes do processo.

Oferecer a esses candidatos um espaço de interlocução permite que se compreenda a sua história, favorecendo a elaboração das motivações que fomentam a demanda de ter um filho. Existem mais de cem grupos de apoio aos candidatos interessados em adotar, difundidos nos principais estados brasileiros (ACACIO, 2008). Esses encontros têm como objetivo dar apoio e orientações aos candidatos ou pretendentes à adoção, procurando conscientizá-los sobre as particularidades da filiação adotiva. Além disso, visam a difundir uma nova cultura sobre a adoção, buscando soluções para crianças e adolescentes destituídos de uma relação familiar.

Contudo, os profissionais envolvidos nesse campo devem estar cientes do caráter imprevisível da organização psíquica da parentalidade. O psiquismo do sujeito é complexo, composto por aspectos conscientes e inconscientes. Será somente na interação, a partir do encontro entre adotantes e adotados, que mitos e representações encobertos poderão ser despertados.

Ou seja, a decisão de adotar pode ter origem nas mais variadas motivações, conscientes e inconscientes, as quais estão relacionadas à história e às fantasias infantis de cada membro do casal adotivo. Para muitos autores (FILHO, 2008; TRINDADE-SALAVERT, 2010), avaliar essas diversas motivações para adoção tem se mostrado fundamental para se compreender a organização psíquica da família adotiva. De encontro a essa argumentação, Weber (1997) constatou, em suas pesquisas com famílias adotivas, que não existe relação entre a motivação dos adotantes e o sucesso da adoção.

A divergência entre esses pontos de vistas nos leva a pensar no cuidado que os profissionais do campo da psicologia devem ter em suas afirmações, que por vezes acabam impregnadas de causalidade. O papel do psicólogo talvez seja muito mais buscar reflexões, indagações quanto às múltiplas variáveis envolvidas, em vez de formular afirmações reducionistas. 
Lançamos aqui uma hipótese, que talvez permita o entendimento da contraposição apresentada, sem tornar os dois pontos de vista excludentes. Propomos a ideia de que motivações têm sua fonte no narcisismo. Dependendo do nível narcísico em detrimento da capacidade de alteridade, a cegueira para com as necessidades do filho pode se instalar, e com isso os vínculos de filiação ficam ameaçados. Tal compreensão supõe que o sucesso ou o insucesso da parentalidade e da filiação adotivas seriam influenciados pela rigidez do funcionamento narcísico.

O narcisismo privilegia as necessidades do eu e do ideal de eu, mantendo o sujeito no mundo dele mesmo. A capacidade de alteridade corresponde à capacidade de se colocar no lugar do outro na relação interpessoal (DICIONÁRIO INFORMAL, 2012).

A alteridade não pode ser confundida com filantropia. $\mathrm{Na}$ atitude filantrópica pode haver certo grau de narcisismo, enquanto na alteridade ocorre à superação de tendências egoístas em prol das necessidades do outro. Levinzon (2000) afirma que no Brasil, na maioria das vezes, a adoção só é efetivada quando algo falhou, tanto para a criança, quanto para os pais. Logo de início, ela define o processo de adoção como uma solução para alguma falha ocorrida. A autora também considera a hipótese de que, no processo de filiação e de parentalidade, os possíveis distúrbios têm como origem as dificuldades psíquicas para lidar com as feridas/falhas narcísicas.

No caso de uma motivação filantrópica, em que hipoteticamente "nada" haveria falhado da parte dos pais, pensamos que o narcisismo estaria relacionado à idealização do amor, segundo a qual o amor seria capaz de superar qualquer coisa. Como as relações são ambivalentes em sua essência, a idealização do amor oferece alicerces frágeis e cindidos para a construção do vínculo parento-filial.

Os pais adotivos podem ficar como ideais, como heróis que salvaram seu filho de uma origem ruim, não dando espaço para que este seja diferente do "ser bom filho" em agradecimento. Sendo assim, é como se não fosse permitida a expressão da agressividade, de sentimentos hostis inerentes a qualquer relação humana. Peiter (2011) afirma que as atitudes filantrópicas, imbuídas de sentimentos de culpa, onipotência e desejo de salvação, surgem como defesas ao próprio desamparo, sendo narcísicas em seu fim. 
Por outro lado, ressaltamos que o narcisismo não deve ser considerado vilão, pois, paradoxalmente, ele também é fundamental no investimento libidinal dos pais para com os filhos, viabilizando as identificações. Peiter (2011) e Rotenberg (2011) discorrem sobre esse argumento, alegando que o filho precisa ocupar um lugar no narcisismo dos pais para depois desocupá-lo, uma vez que no desejo de ter filho há o desejo de ter uma continuidade de si, como já foi descrito no capítulo anterior. Lembrando que este é outro paradoxo na parentalidade e na filiação: a apropriação do filho narcisicamente e altruisticamente nas funções paternas e maternas, para posteriormente permitir a sua individuação.

Alguns pais adotivos desejam muito adotar crianças com aparência física semelhante a seus padrões biofísicos, de modo que os elementos de semelhança facilitem os processos de identificação, atendendo as exigências narcísicas (PEITER, 2011). Muitas pessoas são contra isso, achando que devem dissuadir os candidatos de tal propósito, mas a extensão dos significados dessas condições deve ser profundamente pensada e, em última instância, respeitada.

Peiter (2011) chama a atenção para as adoções de crianças maiores, nas quais os pais têm o desafio de ajudar o filho na organização do self de forma a incluir sua pré-história e a história atual, mantendo a função especular tanto da criança como do ambiente novo no qual ela está inserida. Por fim, o autor destaca a ideia da atenção cuidadosa ao serem feitas relações entre os diversos destinos de uma adoção e um determinado tipo de motivação. Tal cuidado se deve à singularidade do funcionamento mental familiar. Por isso, enfatizamos que neste trabalho serão pontuadas algumas situações e fantasias observadas na clínica por diferentes autores, mas tendo em vista a sua utilização como configurações possíveis, e não como caminhos fadados a um único destino.

\section{2}

\section{A parentalidade e a filiação adotivas: conflitos e fantasias}

A condição da parentalidade e da filiação adotivas é um desafio, na medida em que a família será constantemente colocada à prova na sua capacidade de suportar o que está "solto", separado, dissociado, achando-se de um lado os laços biológicos e de outro, os laços jurídicos e psíquicos (LÉVY-SOUSSAN, 2006). Diante disso, a lei terá um valor continente nessa "soltura", pois permitirá a 
sustentação da descontinuidade da filiação biológica com a fundação da filiação afetiva pelo discurso jurídico.

Segundo Lévy-Soussan (2006), sem o asseguramento do discurso jurídico, a família não consegue suportar por conta própria a dissociação. Tal importância da lei ocorre porque o jurídico reconhece socialmente a interrupção da filiação biológica e dá lugar à filiação adotiva. No plano psíquico, a garantia do jurídico para a validade da filiação adotiva permite que pais e filhos experimentem, até certo ponto, seus sentimentos hostis.

Como já mencionado no capítulo anterior, entendemos a filiação (LévySoussan,2006) como a composição de três eixos: filiação biológica, filiação jurídica e filiação afetivo-imaginária. No contexto da adoção, a filiação biológica está dissociada da filiação adotiva, o que exigirá mais do eixo jurídico e do afetivo-imaginário.

Para auxiliar na compreensão, recorremos à imagem de um tripé, cujos três alicerces promovem uma harmonia entre si. No caso da adoção, o papel do jurídico e do afetivo será fundamental na reestruturação da base dos eixos da filiação, já que o eixo biológico terá que ser ressignificado, por conta de sua presente "ausência". Para Lévy-Soussan (2006), é muito comum, na família adotiva, que a criança questione os pais sobre a legitimidade do eixo jurídico e do afetivo. Ou seja, a criança tem dúvida a respeito do que é ou não verdadeiro, se o "nosso vínculo pode ser sustentado".

O trabalho psíquico próprio do processo de filiação será a simbolização de questões relacionais e narcísicas, considerando o conjunto da dupla parental como fonte originária do filho adotivo. Filho (2009) reforça que à família adotiva resta vivenciar intensamente a sua condição de vinculação afetiva e toda a sua história de adoção, sem se sentir agredida por sua diferenciação. Contudo, sabemos que, no mundo inconsciente, as leis da lógica fogem às da razão, abrigando fantasias desconhecidas, cuja incidência pode ser tóxica à saúde do vínculo parento-filial.

Em filhos adotivos, algumas fantasias e medos são apontados como frequentes. Alguns deles são comuns ao mundo interno infantil, porém, no caso da adoção, podem se tornar assustadores devido à concretude das descontinuidades. Freud, em Romances familiares (1909 [1908]), fundamenta a discussão sobre a diferença entre a experiência de abandono e a fantasia de abandono. $\mathrm{O}$ autor 
observou que havia a fantasia infantil marcada pelo desejo de a criança substituir os pais verdadeiros, fantasiando que, de algum modo, elas poderiam ser adotivas.

Freud justifica esse desejo afirmando que a criança primeiramente quer igualar-se a seus pais, mas quando percebe que eles não são tão nobres, nem tão perfeitos quanto imaginava, tenta substituí-los, imaginando-os como madrasta e padrasto. A fantasia de ter sido adotada é uma maneira de manter a figura idealizada dos pais, tudo como uma tentativa saudosa dos primeiros tempos da infância. Esta fantasia permearia a vida imaginária de muitos sujeitos, mas, na daqueles que foram entregues, há uma realidade que atravessa a fantasia, pois existem efetivamente "outros" pais (os biológicos), e o "descontentamento" natural com os pais adotivos libera uma série de ansiedades.

Por essa razão, o filho adotivo, na realidade, "vive o romance familiar que outras crianças vivem na fantasia" (KERNBERG, 1985, p. 295). Portanto, segundo essa autora, o romance familiar do filho adotivo teria três momentos. Em um primeiro momento, a percepção real de que existem outros pais (biológicos) ausentes, e por isso suas imagos seriam propensas a fortes projeções idealizadas. A transposição disso ocorreria quando a criança se desilude com a família biológica e se contenta com a nova família adotiva. Haveria também o momento de a criança perceber-se como uma criança temida ou desvalorizada pelos pais adotivos. A autora os define como momentos naturais desse romance familiar adotivo, cujo desfecho deveria ser o alcance, pela criança, de uma aceitação emocional por parte de ambos os conjuntos de pais, integrando-os.

Filhos adotados reencontram pessoas substitutas com as quais criam uma íntima relação afetiva. Quando adotados ainda bebês, devem encontrar alguém que estabeleça uma comunicação sensível às suas necessidades primitivas, de modo que sejam acolhidas. Como o psiquismo do bebê está em desenvolvimento, este precisará do psiquismo da mãe adotiva para metabolizar as privações vividas. O pensar e os sentidos dados a esse momento inicial surgirão a posteriori.

Winnicott (1971) indica que muitos dos problemas que aparecem na relação pais e filhos adotivos não são consequências da adoção propriamente dita, mas de carências anteriores à adoção. Acreditamos que este seja um ponto relevante a ser discutido mais adiante. O autor destaca a dificuldade que os pais têm de se tornarem pais de uma criança com carências básicas, que necessita por vezes de que estes exerçam um papel até terapêutico. De acordo com Rotenberg (2011), só 
o vínculo amoroso com o filho adotivo poderá frear ansiedades e dores psíquicas, permitindo a formação da esperança, do deixar cuidar-se, e dessa forma ascender a uma capacidade maior de simbolização, mitigando possíveis atuações compulsivas e confrontos que busquem colocar à prova o amor dos pais.

Como descrito por Kernberg (1985), a criança adotiva possui duas incógnitas em sua vida. A primeira diz respeito ao desconhecimento de quem foram seus pais biológicos. A segunda corresponde às razões da descontinuidade da convivência. A autora acrescenta que, dependendo do temperamento da criança, de suas vivências subjetivas e do meio ambiente em que ela vive, estas duas incógnitas se constituirão como questões centrais na formação de sua identidade, afetando atitudes e relacionamentos.

Ainda conforme postula Kernberg (1985), como resposta às razões de terem sido deixadas pela mãe biológica, algumas meninas podem ter fantasias de que foram rejeitadas por não terem um pênis, ou por seu corpo ser mau. Ou seja, por terem algo de errado em seu corpo, não conseguiram agradar às suas mães o suficiente para que estas desejassem permanecer com elas. Propomos que essa ideia seja ampliada, e o filho adotivo, independentemente do gênero, possa vir a considerar-se responsável pelo "abandono".

Em adição, Rotenberg (2011) sustenta que crianças que já sofreram importantes perdas afetivas se apegam com intensidade e desenvolvem sentimentos de possessão em relação à pessoa que lhes oferece um vínculo estável. Como uma ressalva à afirmação da autora, devemos lembrar a formação reativa como mecanismo defensivo, por meio do qual o sujeito pode se colocar em oposição ao movimento desejante de "ligar-se". A grande necessidade de apego pode resultar num medo enorme de vincular-se ou levar a criança/adolescente a desenvolver uma sensibilidade especial para captar as necessidades de seus pais.

Em alguns casos, a criança/adolescente acredita que o amor de seus pais adotivos é condicional, temendo ser abandonado, caso não se comporte de acordo com o desejo destes. As separações também podem ser vividas como novas perdas e se tornarem fontes de grande ansiedade. Para Rotenberg (2011), os filhos adotivos têm a sensação difusa de se sentirem filhos e não filhos concomitantemente. É como se sempre estivessem ameaçados de que a ligação com os pais é incerta. A fantasia é que se os pais biológicos os abandonaram, 
então qualquer um poderá fazer o mesmo, constituindo a crença de que nenhuma relação oferece garantias.

Problemas de conduta e contestações surgem como ratificações do amor dos pais. Nas palavras de Marinopoulos, Sellenet e Vallée (2003), "filhos adotivos precisam testar o desejo daqueles que fizeram a escolha de serem pais, e nesta situação eles possuem uma capacidade considerável de desestabilizá-los” (p. 177). Soma-se a isso o fato de os filhos adotados tenderem a se sentir negligenciados, podendo direcionar a agressividade tanto para os pais quanto para si mesmos (KERNBERG, 1985; 1978).

O vínculo entre adotantes e adotado acaba sendo consolidado na legitimidade conferida ao lugar do filho na trama geracional. Gomes e Iyama (2001) defendem que a criança terá uma menor propensão a conflitos e a sintomas caso a família a inscreva na malha simbólica familiar. Pensamos que tal argumento é insuficiente, porque a inscrição por si só não é capaz de dar garantias, já que são fundamentais as representações em torno dessa inscrição, cujos significados podem ser dos mais amorosos aos mais hostis na fantasia familiar.

Levy (2009) sustenta que "a criança deverá ser investida de um mandato transgeracional, fundado na trama do narcisismo parental” (p. 68). Se houver qualquer dúvida sobre a filiação, nem sempre consciente, Marinopoulos et al. (2003) pontuam que essa dúvida será passada para cada membro da família e poderá desencadear uma patologia.

$\mathrm{Na}$ literatura, também existem formulações de similaridades entre os mitos e as fantasias pertencentes aos pais adotivos. Determinadas defesas dos pais adotivos, relativas à origem do filho, influenciam, de forma significativa, a maneira pela qual este último representará sua história. Certos pais tendem a negar a descontinuidade biológica, e tal negação da realidade cria uma armadilha para a parentalidade e para a filiação adotivas. Nem a criança pode adotar psiquicamente os pais, nem estes a adotam no nível inconsciente. Efetivamente, a expressão dessas fantasias pode ir se instalando pouco a pouco (TRINDADE-SALAVERT, 2010).

Conforme Silva (2011), se existir na fantasia uma dinâmica competitiva por parte dos pais adotivos em relação aos pais biológicos, o filho adotivo poderá sentir-se dividido entre as duas histórias familiares, acuado pelo passado e o 
presente. Kernberg (1985) aprofunda esta ideia, sustentando que o fato de haver dois conjuntos de pais facilita a divisão do superego e das identificações, assim como a rigidez do eu ideal.

Para Lee Fu e Matarazzo (2001), o fato de a criança ter uma herança genética diferente da herança de sua família adotiva oferece conteúdos para as fantasias dos pais, levando-os a colocar a criança em uma condição "especial". Marinopoulos et al. (2003) explicam que, para esses pais adotivos, a origem de seu filho constitui um buraco narcísico, e esta realidade provoca tanta dor que os obriga a se proteger por meio de mecanismos como spliting e negação.

A partir dessas colocações, podemos afirmar que a aceitação, por parte dos pais adotivos, da realidade do "buraco" biológico auxilia o filho na construção de uma concepção integrada da própria imagem. É importante para a criança sentir que os pais adotivos respeitam as figuras dos pais biológicos. As crianças "manifestam uma aliança com essas primeiras figuras parentais de sua vida, mesmo alimentando uma possível raiva da mãe biológica em virtude do abandono que sofreu" (SILVA, 2011, p. 85).

Com efeito, resta aos filhos adotivos fazer o luto e aceitar seus pais adotivos (MARINOPOULOS et al., 2003). Apesar de considerar pertinente a colocação das autoras, preferimos a ideia de Kernberg (1985), por achá-la mais completa. Para a referida autora, o filho adotivo deve aceitar tanto a sua condição de adotivo, como a de filho natural de pais biológicos desconhecidos, ou de pais que não são mais seus responsáveis (como no caso de crianças maiores).

Por outro lado, a realidade da história, sobretudo a condição de "adotivo", pode ser usada como uma defesa. Isso pode vir a impedir que o casal tenha acesso à elaboração de dificuldades em seu papel de pais no presente. Particularmente, as suas dificuldades em interagir como casal capaz de cuidar de um filho (ROTENBERG, 2011). Essa ideia remete à enunciação de Winnicott (1971), segundo a qual os problemas relacionais não decorrem da adoção propriamente dita, mas sim do mundo inconsciente. Portanto, não tem fundamento esta fala encontrada em meios sociais: "É porque é adotado". As idiossincrasias da adoção são coloridas pelas fantasias infantis de pais e filhos, e por suas representações inconscientes, instaladas antes mesmo do advento da adoção.

Podem existir pais cujo funcionamento relacional é engolfar o filho, de modo que se apropriam da subjetividade deste, negando sua singularidade e 
acreditando que todas as suas escolhas e atitudes são justificadas somente pelo fato de serem pais (ROTENBERG, 2011). A dificuldade em lidar com a singularidade do filho adotivo real, não o idealizado, pode gerar sentimentos ambivalentes em relação à criança e uma intensa frustração.

Uma fantasia frequente é atribuir à genética (aos pais biológicos) alguma particularidade ou os comportamentos "reprováveis" do filho. A partir do embasamento de Lévy-Soussan (2006), já explicitado, podemos pensar que, para esses pais, talvez a "soltura" da filiação biológica não tenha sido suficientemente integrada à história. Por isso, facilmente responsabilizam a genética por algo fora deles e impossível de ser legitimado, ou seja, o que há de ruim em seus filhos, aquilo que gostariam de extirpar de seus filhos.

Por outro lado, os pais adotivos sentem pavor de que o filho possa um dia preferir os pais biológicos, e assim os abandonar. Em muitos casos, esse pavor, que revela falta de confiança no vínculo parento-filial, é a razão de não falarem sobre a origem do adotado. Uma investigação sobre quais fantasias estariam causando esse pavor provavelmente levaria esses pais a entrar em contato com as suas próprias ambivalências.

Além desses medos e fantasias, Levinzon (2000) observou a presença de "fantasias de roubo" em alguns pais. Seria como se eles em algum nível acreditassem que tivessem roubado a criança dos pais biológicos. Kernberg (1985), aprofundando esta observação, diz que a fantasia de roubo, por parte da mãe adotiva, está relacionada às suas fantasias infantis de roubo dos bebês de sua própria mãe. Tais formulações tornam mais clara a concepção de que as repercussões psíquicas não são provenientes apenas da adoção, mas sim de questões primitivas e edípicas que se evidenciam nesse fato.

Os efeitos das fantasias de roubo são drásticos, do ponto de vista da autora (LEVINZON, 2000), podendo gerar ansiedades persecutórias e sensações de perigo com relação ao amor do filho e à legitimação da filiação. Ela assinala que, assim como percebido nos filhos adotivos, os pais também podem ter dificuldades em lidar com experiências normais de separação, que são características do ciclo vital.

A função da família é justamente ser continente dessas ansiedades, angústias e fantasias, metabolizando-as para o filho. Caso não haja esta função continente estável, podem surgir problemas de convivência em vários momentos da vida 
compartilhada. Desse modo, os períodos críticos do ciclo de vida abalariam ainda mais a trama narcísica familiar já fragilizada. Talvez seja por isso que as pesquisas apontem para tantos problemas em adolescentes adotivos e suas famílias.

As fantasias presentes no período de adaptação da criança na família se exacerbariam na adolescência, tanto para os pais, quanto para os próprios adolescentes. Os pais, ao se sentirem ameaçados com a história de origem do filho, evitam comentar o assunto, com medo de que seu filho, quando iniciar a vida adulta, possa preferir os pais biológicos. Esse temor do abandono que os pais sentem pode interferir nos processos naturais de diferenciação e de individuação próprios dessa fase. Mas essa discussão será desenvolvida mais adiante.

Portanto, como foi descrito, apesar de haver as melhores intenções por parte dos pais, os medos e as fantasias existem, sendo a elaboração e a legitimação dos mesmos o único modo de eliminar os seus efeitos tóxicos. Rotenberg (2011) defende a ideia de que uma das características de realidade psíquica é justamente sentir como reais os sentimentos, para assim poder suportar a dor. $\mathrm{O}$ fato de ser adotado não implica uma psicopatologia específica mais reativa às questões da origem e do abandono, questões que devem ser entendidas e elaboradas pelos pais.

\section{3}

\section{Informações sobre a adoção e o mito de origem}

Certamente, é uma unanimidade, entre os autores, reconhecer a importância de se falar precocemente com a criança sobre a adoção (SILVA, 2011; ROTENBERG, 2011; PEITER, 2011; MARINOPOULOS et al., 2003; SOUZA e CASANOVA, 2011). Como já foi muito mencionado, para o filho adotivo constituir sua identidade, ele precisa que sua família adotiva legitime seu lugar na cadeia geracional e, para isso, é necessário legitimar sua história. Um dos recursos para legitimar a história é por meio de narrativas acerca da origem e do encontro com a nova família. A narrativa da condição da adoção parece ter uma dupla face, tanto pode auxiliar os filhos e os próprios pais adotivos na superação de lutos e na elaboração de sua experiência emocional, como pode remeter às vicissitudes da origem da criança. 
Com relação às vicissitudes da origem do adotivo, existe $\mathrm{o}$ fato incontestável de que o filho adotivo vivencia uma dupla fidelidade. Ele tem um elo tanto com a mãe da origem, apesar de rompido, quanto com a mãe adotiva, elo este criado pela cultura e pelo vínculo afetivo (ABRÃO, 2011). Sendo assim, o filho adotivo tem como registro que quem o gerou não está perto dele, e o lugar daqueles que lhe oferecem existência e pertencimento é ocupado pelos pais adotivos. Para os pais adotivos, a presença de outros que não eles mesmos faz da origem uma possível lembrança ameaçadora, devido à fantasia de deslealdade: “Será que ele preferirá os pais biológicos?" Nesse contexto de ambivalências, o apagamento da filiação biológica, nas narrativas familiares, pode surgir como um recurso para afastar possíveis ameaças ao lugar de cada um. Pensamos que dessa maneira se constitui um romance familiar complexo, que embasa as idiossincrasias das narrativas sobre a história de origem do filho adotivo.

Para um filho biológico, é menos ameaçador questionar as origens, quando testa o seu lugar de pertencimento no contexto familiar. Abrão (2011) justifica a afirmação anterior, relembrando que a questão do senso de pertencimento para o adotivo é mais complexa, porque ele lida com um duplo pertencimento. Como muitos dos processos psíquicos remetem à origem, os processos se tornam trabalhosos para os envolvidos. A autora exemplifica isso, pontuando a questão da diferenciação. Ela menciona que a diferenciação é um desafio na medida em que se remete sempre às origens e ao desconhecido. Esta tarefa trabalhosa é perfeitamente viável, segundo Abrão (2011). Mas a autora ressalta que, para ser possível uma formação da identidade com saúde emocional, os pais adotivos devem oferecer apoio e participação aos filhos que adotaram. A esta ideia acrescentamos a importância de esse apoio e participação viabilizar a elaboração da história de origem, já que ela permeará muitos processos da constituição psíquica e da identidade do filho adotivo.

Golse (1999), em seu estudo sobre o desenvolvimento da linguagem, faz algumas definições com base nas classificações de Ferdinand Saussure. Golse (1999) pontua a diferença entre fala e língua, definindo a primeira como algo de ordem individual e a segunda, de ordem coletiva. A linguagem corresponderia à potencialidade humana de se inserir em um sistema de língua e ter a capacidade de atualizá-lo. Esse autor especifica que na linguagem existe uma música, denominada prosódia, que irá codificar as palavras em uma específica tonalidade 
afetiva. Não é possível para o bebê decodificar as palavras, mas ele decodifica a prosódia, identificando as variadas tonalidades emocionais que lhe são enviadas.

Fazendo referência às crianças adotadas, Golse (1999) destaca que, no passado, falava-se que os pais fariam a revelação da origem à criança no momento em que esta pudesse compreender. $\mathrm{O}$ autor indaga sobre qual elemento deveria ser particularmente entendido, já que é impossível determinar os sentidos que a criança dará à sua história de origem. Na espera pela compreensão da criança o tempo passa e as dúvidas sobre a compreensão e a reação da criança só aumentam, e menos capaz a família se sente de contar a verdadeira história.

Hoje em dia, porém, como nota Golse (1999), a ideia mais aceita é oferecer a informação para a criança desde cedo, de forma gradual, sem configurá-la como uma discussão solene. Mesmo quando a criança ainda não entende as palavras especificamente, os pais devem falar sobre sua história, de modo que transmitam a atmosfera emocional familiar. Dessa maneira, a criança irá se habituar aos aspectos afetivos envolvidos em sua origem.

A linguagem oferece uma ponte entre o sujeito e o objeto. $\mathrm{O}$ bebê se individualiza por meio da linguagem, a qual permite o estabelecimento de uma ligação com o objeto. Golse (1999) afirma que qualquer ato de palavra significa simultaneamente o de uma ligação. Recorremos a esta ideia para pensar que falar a história de origem para o filho é, de certa forma, poder ligar-se a esta realidade referente à formação da parentalidade pelo laço afetivo.

Situações traumáticas recebem várias significações e, ao longo da vida, vão adquirindo novos significados. Peiter (2011) afirma que a narrativa da história constitui uma das funções parentais. As informações sobre a origem da criança permitem a construção de sentido a possíveis recordações e fantasias, viabilizando a integração entre passado, presente e futuro. O discurso dos pais sobre a história da criança adotiva tem como função essencial a simbolização de situações traumáticas.

$\mathrm{O}$ ato de contar a história de origem para a criança adotiva pode ser pensado como um momento de transmissão mítica de sua criação, importante tanto para a consolidação da parentalidade como para a filiação. Essa transmissão de saber as informações fortalece o vínculo entre pai e filho, tendo, pois, uma função estruturante, ao incorporar o que um representa para o outro. 
No intuito de reforçar essa ideia a respeito das famílias adotivas, valemo-nos de Eiguer (2012), em sua formulação sobre os costumes de grupos empresariais. Segundo o autor, uma das razões para se contar a história da empresa no momento de uma contratação, ou repeti-la com frequência aos funcionários, é a consolidação do vínculo grupal pela aliança e engajamento. De acordo com o autor, "o ato de pertencer a um grupo, dentre os quais a família, talvez se configure por um entrelaçamento de histórias, as quais remetem aos mitos" (p. 24).

Para Eiguer (2012), o reasseguramento do pertencimento, por exemplo, ocorre em cada reunião de família, quando são contadas as mesmas histórias. Tal hábito consolida a adesão grupal e os lugares na árvore genealógica. Lembremos que o mesmo acontece em encontros entre velhos amigos, nos quais também ocorre a repetição de histórias antigas, vividas conjuntamente. $\mathrm{Na}$ adoção, o contar e o recontar a história talvez tenha essa função, de reassegurar a filiação e a parentalidade.

Portanto, consideramos que a informação precoce da adoção tem como principais funções o desenvolvimento da vivência de pertencimento, a ligação libidinal da criança à sua realidade histórica e a viabilização de simbolização dessa realidade. A partir da narrativa parental, a criança inventará sua própria história, não totalmente respaldada na realidade, mas também não tão fora dela. A família da realidade se superpõe às imagos introjetadas, as quais certamente são bem diferentes dos pais reais, e assim são constituídas as lembranças encobridoras (MARINOPOULOS et al., 2003).

Revelar a história não consiste, pois, em uma mera revelação de fatos que conferem sentido e continuidade à vida da criança. Trata-se, na verdade, da possibilidade de assimilação psíquica daquilo que a criança viveu e da constituição de quem ela é. A criança conhece a verdade, mesmo que num registro de experiência emocional. Os fatos e ocorrências pelos quais ela passou acabam deixando marcas mnêmicas, ainda que fora do registro da palavra (SOUZA e CASANOVA, 2011).

Silva (2011) explica que, por mais que os pais saibam pouco ou nada sobre a história pregressa de seus filhos, é importante terem disponibilidade de falar o que sabem, pois isso significa que reconhecem a existência de uma história. Conforme a autora, essa disponibilidade representa que, mesmo havendo na 
história muita dor e tristeza, estas podem ser encaradas e respeitadas em sua realidade. Poder falar sobre a adoção é poder tolerar a angústia que remete a um estado de incompletude, que é definitiva e inerente a todo ser humano (ROTENBERG, 2011, p. 44).

Marinopoulos et al. (2003) apontam que às vezes os pais temem falar com o filho com medo de que este possa rejeitá-los. Mas, se não falarem, negarão ao filho a possibilidade de perceber que não existem dívidas para com os pais genitores, e isso poderá impedi-lo de se ligar de fato ao mundo mítico da cadeia genealógica dos pais adotivos. Se os pais não puderem entrar em contato com um possível sofrimento que a origem do filho lhes causa, este perceberá que o tema é proibido. Consequentemente, ele deixará de perguntar, podendo inibir a tendência natural de buscar o saber (ROTENBERG, 2011, p. 50).

De acordo com Kernberg (1985), várias forças tornam os filhos adotivos vulneráveis a desenvolver problemas psicológicos de aprendizagem, ao que ela denominou inibições na aprendizagem, sendo uma dessas forças o não falar sobre a adoção. Aos olhos da autora, isso se daria quando a adoção é tratada como um segredo, não propriamente de fatos, mas de sentimentos em relação a esta realidade. Esse segredo incute na criança a proibição da curiosidade em saber, em conhecer. Isso lembra os efeitos dos mecanismos de defesa de deslocamento e de isolamento. O primeiro corresponde ao deslocamento do afeto para representações não diretamente ligadas ao conflito original. Já no isolamento são rompidas quaisquer conexões associadas ao conflito original (LAPLANCHE e PONTALIS, 2001).

Souza e Casanova (2011) apontam outra faceta dos efeitos que o segredo da adoção provoca. As autoras reforçam a ideia de que o mais impactante para a criança é perceber que dedicou amor e confiança a pessoas que foram capazes de enganá-la. Tudo passa a ser vivido como irreal, inclusive a própria percepção de si mesma. Por isso a criança estará mais protegida e poderá se constituir sobre bases mais sólidas, se souber o que aconteceu.

$\mathrm{Na}$ literatura, encontramos algumas sugestões de dispositivos que auxiliam os pais em sua narrativa sobre a adoção, como, por exemplo, a construção de um álbum, a escrita de um relato que permita colocar em palavras esclarecimentos de situações iniciais. O relato acaba se tornando um mito de infância oferecido à criança (PEITER, 2011). Outro recurso muito válido, relembrado por Souza e 
Casanova (2011), é o uso de livros de história específicos para adoção, ou de contos infantis adaptados a essa realidade particular, como a história de Tarzan.

Frequentemente, as dificuldades se resumem ao momento de dizer e ao que dizer à criança. Rotenberg (2011) notou, com a experiência clínica, que os pais adotivos, ao informarem sobre a adoção, por vezes colocam ênfase em uma situação de abandono, mesmo que isso seja inconsciente. Para a autora, a ênfase ocorreria devido à identificação dos pais com o sofrimento que possivelmente seus filhos teriam vivenciado. Mais uma vez, o que estaria ditando as regras seriam as projeções dos pais, ou seja, suas próprias vivências de desamparo infantil, o que revela a incapacidade de fazerem distinção entre as suas vivências e a vivência dos filhos.

Em adição a essa formulação, pensamos que a ênfase no abandono, mesmo que inconscientemente, talvez ocorra porque o elo dos pais adotivos com seu filho só foi possível pela interrupção do elo com seus genitores. De fato, foi a privação que viabilizou a constituição dessa família, mas dependerá de cada sujeito dar a essa família os significados, sejam dramáticos, traumáticos ou benignos. Para Kernberg (1985), a melhor saída é que cada uma das partes valorize os ganhos e não o que foi perdido. Devemos ressaltar, porém, que não basta só falar dos ganhos, é preciso que os pais de fato vivenciem emocionalmente que os ganhos puderam mitigar as perdas e as privações, mas para isso, as mesmas precisam ser admitidas.

Cabe mencionar que muitas vezes o ato de contar sobre a origem é feito em nome da criança, mas são os próprios pais que precisam registrar, ouvir novamente, para legitimar o seu lugar, a sua parentalidade. Como foi descrito, há muitos argumentos e justificativas na literatura para se revelar a verdade desde cedo. Contudo, em alguns momentos parece que os autores descrevem uma cartilha de "bom comportamento", especificando como os pais devem ou não proceder. Acreditamos que seja escassa a compreensão científica sobre os possíveis desdobramentos da informação da adoção, sobre os conteúdos que são transmitidos nesse relato, sobre o que é informado com facilidade, ou o que é mais facilmente omitido, ou mesmo sobre as variadas intenções de uso da informação.

A respeito deste último ponto, quereremos destacar que os pais podem ficar repetindo inúmeras vezes a história da adoção, mais por uma necessidade própria do que para o bem de seus filhos. Eles também podem contar a história para 
cumprir o que é tido como certo e assim se verem livres de qualquer questionamento. Levantamos essas possibilidades para lembrar que as histórias possuem singularidades, e cumprir a cartilha por vezes pode camuflar as prosódias e as fantasias inconscientes presentes na transmissão do que chamamos a informação do saber mitológico sobre a origem do laço adotivo.

A palavra mito procede do grego mythos, estando ligada ao verbo mythevo, o qual significa a criação de uma história imaginária. Sendo assim, ao falarmos de mito nos referimos a uma crença, a uma tradição, mas não necessariamente ao que aconteceu. De acordo com Moretto e Terzis (2010), os mitos são considerados sinais de ajuda ao ser humano, na procura da verdade sobre si mesmo. Ou seja, na busca de se decifrar. Green (1980) afirma que o interesse pelo mito existe justamente porque ele estabelece um encontro com as profundezas do antigo, atualizando o passado no presente, e mostrando, assim, que as questões antigas não estão mortas. O mito é o testemunho da pré-história, bem como o inconsciente.

Como uma de suas funções, o mito aborda poeticamente medos, dramas e terrores da humanidade, possibilitando o acesso à conscientização e à elaboração dos mesmos. Daí a utilização dos mitos para o entendimento de situações psicológicas (MORETTO e TERZIS, 2010). Desde o início, Freud reconheceu o valor dos mitos para entender o psiquismo, utilizando-os para pensar as verdades mais profundas do sujeito, as quais expressam aspectos fundamentais para a constituição do funcionamento emocional.

$\mathrm{Na}$ psicanálise, as fantasias originárias, assim como os mitos, têm o caráter de explicação de enigmas. É preciso criar, para cada sujeito, uma teoria de sua própria história, e essa origem é representada pela cena primária - o coito dos pais. Abrão (2011) entende que, na adoção, a cena primária está deslocada do casal parental adotivo, e assim o filho adotivo atualiza a questão de que qualquer ser humano poderia ser adotivo, na medida em que ninguém escolhe os pais que tem, e também não testemunha a cena primária. Pensamos, a partir dessas colocações, se a representação do biológico ganha força justamente como proteção frente ao desamparo desses enigmas originais.

Retomaremos agora o mito de Édipo, usado por Freud para desenvolver um de seus mais importantes conceitos: o complexo de Édipo. Mas iremos enfatizar os aspectos do mito que acreditamos exemplificar a busca do sujeito pela verdade 
de sua origem, ou seja, a busca dos enigmas referentes a si mesmo, à própria existência.

Em última instância, podemos dizer que o mito de Édipo conduz à constatação de que o sujeito é, inevitavelmente, constituído por uma falta: a castração, que é transmitida de pai para filho (BRUNETTO, 2008). O homem sente desamparo diante da incompletude, que Freud chamará de castração, da qual nunca nos libertaremos. Brunetto (2008) destaca que, acima de tudo, Édipo mostrou-se um curioso e, por isso, um decifrador de enigmas. Retomemos o mito em si, para o desenvolvimento de algumas ideias.

A família real de Tebas, representada pelo rei Laio e a rainha Jocasta, teve sua vida marcada por uma grande tragédia, da qual tentaram escapar, mas sem qualquer êxito. Laio recebeu a profecia do oráculo de Apolo que, se gerasse um filho, este o mataria. Devido à profecia, quando nasceu seu primogênito, para evitar esse destino, Laio decidiu matá-lo. Mandou furar-lhe os pés e matá-lo em Monte Citerão. No entanto, o servo que havia sido designado para tal incumbência salvou o menino da morte.

Mais tarde, o menino fora nomeado Édipo, cujo significado é "pés inchados". Ele foi adotado pelo rei de Corinto, que não podia ter filhos. Adulto, Édipo ficou sabendo da maldição que pesava sobre ele: iria matar seu pai e se casar com a própria mãe. Acreditando que seu pai biológico era o rei Polibio, já que ignorava a verdade de sua origem, resolveu fugir de Corinto, a fim de evitar que tal maldição se concretizasse.

Em seu percurso, Édipo se deparou com um cortejo em uma encruzilhada, e acabou brigando com um dos homens até matá-lo. Não sabia que se tratava, na verdade, do rei Laio, seu pai biológico. Após desvendar o enigma da esfinge, que aterrorizava Tebas, casou-se com Jocasta, com quem teve quatro filhas.

Devido a uma peste que castigava Tebas, Édipo enviou Creonte, seu cunhado/tio, ao oráculo de Apolo para obter alguma predição de como ajudar o povo, que lhe suplicava salvação. A mensagem do oráculo foi que deveriam expulsar, ou matar, o assassino do rei Laio.

Como Édipo prometeu que faria de tudo para salvar a cidade, começou a investigar tal história, e para isso mandou chamar Tirésias. O velho sábio e cego hesitou em revelar o mistério, dizendo que saber a verdade não seria bom para Édipo nem para ele. Após muitos insultos de Édipo, o subordinado de Apolo 
afirmou ao rei que o assassino procurado era ele mesmo. Sem acreditar, Édipo desconfiou de o velho estar mancomunado com Creonte para tomar o trono.

Após essa conversa, Édipo dividiu com Jocasta a situação e as informações de que dispunha. Por sua vez, a mulher o aconselhou a despreocupar-se, pois tais profecias não eram cumpridas, pelo simples fato de que nenhum mortal poderia prever o futuro. Como justificativa, ela narrou o destino que Apolo havia determinado a Laio e que não se cumprira. Édipo, então, começou a perguntar à mulher sobre a morte de Laio. Conforme ia buscando respostas, mais próximo ele ficava da verdade de sua origem e da fatalidade de sua história.

O desenlace ocorre quando Édipo finalmente mandou chamar o pastor que lhe salvara a vida e o entregara ao rei de Corinto. O pastor lhe revelou que o recebera de um servo. Este último, ao ser chamado, confirmou a Édipo ter recebido ordem de Jocasta para matar seu filho, porém, por comiseração, não atendera ao pedido da rainha e entregara o bebê ao pastor. Desatinado com a verdade, Édipo correu pelo palácio à procura de sua mãe. Descobriu que Jocasta havia cometido suicídio e, assim, ele furou seus próprios olhos, não querendo mais testemunhar as suas desgraças e seus crimes, nem mesmo reconhecer aqueles que já não desejava mais reconhecer.

Pela perspectiva psicanalítica, todo homem vive o drama edipiano, o inefável das relações objetais primárias, e o quanto a própria história primária lhe é estrangeira. Édipo guarda a marca de sua origem em seu corpo (os pés inchados) e em seu nome (sua identidade). A marca da exclusão é eterna, lembrando-lhe em seu corpo a privação de uma vida junto com seus pais biológicos, e assim tornando sua origem de perda e de luto viva e presente o tempo todo. Mesmo sem saber, ele retorna à sua origem, apesar do desvio.

Brunetto (2008) pontua que ser estrangeiro para si mesmo é próprio da condição do sujeito, na medida em que acreditamos na existência do inconsciente. Segundo a autora, "todo sujeito é expatriado de suas lembranças mais antigas, necessitando reconstruir esses capítulos apagados de sua origem" (p. 74). Em acréscimo à ideia da autora, pensamos que, na tentativa de reconstrução da origem, o percurso leva a terras estrangeiras, e é engodo acreditar que, ao se deparar com a verdade, o sujeito encontrará o familiar e se livrará da inquietude. Édipo, o decifrador de enigmas, mesmo tendo buscado a verdade escondida, deformada pelas tramas da linguagem e presa no mal-entendido das gerações, não 
encontrou a completude. A incompletude está concretizada na cegueira, pois, subsequentemente à condição de ver para além dos fatos, ficou sem ver. Tirésias também estampa esta metáfora da castração, pois, apesar de tudo saber, era cego.

A dimensão mais evidente do mito de Édipo, segundo Brunetto (2008), é que ele representa o sujeito que busca o sentido de sua existência na decifração de sua origem no mundo. O encontro de Édipo com a Esfinge também emblema essa busca, cujo enigma a ele proposto tratava-se do ser homem, como aquele que anda pela manhã com quatro pés, de tarde com dois pés e pela noite com três. Lemos o enigma como as três passagens mais significativas do ciclo vital: a infância, a vida adulta e a velhice. Podemos observar que, desde o início até o fim da vida, necessitamos de ajuda das relações objetais, até mesmo o adulto que se apoia sob suas próprias pernas precisa de seus objetos. Édipo precisou de amparo para poder viver, para descobrir o enigma de sua existência, e na velhice apoiou-se em sua filha Antígona.

As questões de Édipo, do começo ao fim da tragédia, envolvem perguntas como: "Quem sou eu"? "Filho de quem"? "Qual é meu lugar no mundo"? "Sou estrangeiro em Corinto ou em Tebas"? Ele não sabia a verdade, porém, mesmo quando a obteve, não pôde se reconhecer nela. Brunetto (2008) considera a verdade como o próprio enigma, pois nunca poderá ser alcançada em sua completude. Se existe algo que sempre está pela metade, tanto na tragédia de Édipo como na vida do sujeito, é a verdade.

Pontuamos que a angústia de encontrar a verdade de sua existência é inerente a todo ser humano. A angústia está relacionada à curiosidade sexual das crianças, que desenvolvem o questionamento clássico sobre a origem dos bebês. $\mathrm{O}$ não saber também faz parte do desamparo. Podemos pensar que no filho adotivo esse aspecto do desamparo está exposto, impondo-se na realidade, talvez exigindo defesas mais rígidas para suportar a angústia, caso não encontre uma contenção psíquica.

Pensamos que a condição de adoção se impõe ao sujeito e realça o enigma da origem inerente ao ser humano. Este dado se mantém vivo e visível a todo instante, metaforicamente, como os furos nos pés de Édipo. Tendo em vista isso, a capacidade de lidar com essa castração a "céu aberto" dependerá de cada família, de cada sujeito. A história de origem se faz fundamental e estruturante para a condição de ser família adotiva, pois também oferece uma verdade parcial acerca 
de onde e porque pertencem a uma mesma cadeia geracional. Contudo, a história se faz incompleta na medida em que o saber de cada história comporta um mistério: um aspecto comparável ao "umbigo do sonho" (FARIAS e BARROS, 2008). Cada vez que o saber é produzido, cria-se o paradoxo de se encontrar o vazio.

A dimensão do vazio está ligada ao impossível, ao indizível, e leva o homem à produção de saber sobre os mistérios da vida. O primeiro deles, pertencente ao universo infantil, ocorre em torno das questões sexuais. A criança produz questionamentos que têm como fonte ansiedades ligadas à origem dos bebês e ao lugar do pai na procriação. Ela busca a verdade do enigma da diferença sexual. A criança quer saber, tem curiosidade pelo sexual, movendo-se nessa direção da busca pelo conhecimento. Farias e Barros (2008) compreendem, a partir da psicanálise, que a sexualidade infantil é uma teoria sobre o não sabido do sexo, ou seja, que a sexualidade é vivida através do complexo de Édipo, que sucumbe ao recalque, portanto, ao desconhecido. Farias e Barros (2008) afirmam que a tarefa de querer entender o enigma da diferença de sexo, feminino e masculino, força o sujeito a encarar o abismo, o mistério e a impossibilidade.

Desenvolvemos essas formulações para respaldar o nosso entendimento acerca do ato de informar sobre a adoção. É um ato de falar sobre a origem, criar um saber e, paradoxalmente, suportar um não responder aos enigmas. A função desse ato é estruturar os laços de parentalidade e de filiação, além de colocar todos os envolvidos a par da impossibilidade de um saber pleno. Como mencionado, a dimensão do vazio pertence a qualquer sujeito, mas pensamos que, na adoção, aparece de modo explícito, a castração se impõe continuamente. Talvez essa constância sem trégua da dimensão do vazio, fonte de grandes ansiedades, acabe exigindo daqueles envolvidos com a adoção um maior trabalho psíquico para elaborar tais ansiedades.

\section{4}

\section{O papel da família extensa e da rede social}

A família extensa é formada por um grupo de pessoas para além da unidade do casal e seus filhos. Portanto, engloba as diferentes gerações, tanto no eixo vertical (avós, bisavós, tios), como horizontal (primos, cunhados). Souza e Casanova (2011) enfatizam a importância da participação da família extensa na 
preparação da chegada da criança. Isso porque o projeto de adoção não diz respeito unicamente ao casal parental, ou à pessoa solteira, uma vez que, em qualquer das situações, as pessoas pertencem a um grupo familiar, e sua vida é afetada pelo mesmo.

Inegavelmente, a família como um todo participa do processo de integrar a criança à cadeia genealógica (MARINOPOULOS et al. 2003, p. 148). Sendo assim, é função da família extensa o reconhecimento da criança como um componente familiar, e este reconhecimento será uma variável que facilitará a criança em sua vivência de pertencimento. A família possui um papel igualmente importante para os pais, pois ela os autoriza a ocupar este lugar, envolvendo-os em suas funções parentais. Podemos dizer que ela possui essa dupla função especular, reconhecendo a nova formação familiar como tal.

Ducatti (2004) pontua que a família deverá transformar uma criança que não compartilha o legado genético em um elemento comum ao grupo, a partir de uma aliança inquestionável. Em consonância com essa perspectiva, supomos que os laços de parentesco na adoção são simbólicos e jurídicos, por isso o grupo familiar se insere como um fator continente ao sustento da filiação imaginário-afetiva. Segundo Filho (2009), são os avós que introduzem o neto na genealogia da família, validando a ascendência do filho adotivo.

Em nossa cultura, a família extensa tem uma contribuição afetiva importante para que os pais e filhos não sejam sobrecarregados de conflitos. Ducatti (2004) ressalta que o mais favorável, para a saúde emocional da criança, seria que a aceitação da família extensa ocorresse desde o início do projeto de adoção. A autora defende o argumento de que compartilhar esse período inicial, antes do surgimento da criança, permite aos familiares já instituir um incipiente lugar psíquico de existência da criança na cadeia geracional.

Contudo, algumas famílias não comungam desse pensamento e desestimulam os candidatos a fazer a adoção com base em histórias de relações adotivas difíceis. Souza e Casanova (2011) observam que, em alguns casos, o desestímulo também ocorre devido à preocupação com a partilha de bens, ou mesmo ao preconceito. Obviamente, a oposição da família extensa não é determinante para a desistência do casal, mas pode constituir um obstáculo a que a criança seja bem acolhida e se sinta realmente um membro da família. (FILHO, 2009). 
Filho (2009) argumenta que uma das principais dificuldades da família extensa em aceitar o adotivo consiste na interrupção biológica da linhagem. Os avós são os que mais se mobilizam com o fato de os netos não terem a mesma origem genética da família. Para os que nutrem esse sentimento, o ato da adoção significa a ruptura da linhagem. Nesses casos, o que se percebe, mesmo que temporariamente, é a inclusão do adotivo com restrições. Todavia, o autor em questão observa que a experiência tem mostrado que a convivência dos pais ou de alguns familiares com os filhos adotivos acaba levando aqueles que segregam a mudar de atitude e acolhê-los.

Além da família extensa, a rede social terá um papel significativo na vida da família adotiva. Como bem explicita Filho (2009), “a adoção está inserida no preenchimento da necessidade psicológica e afetiva da participação na comunidade humana" (p. 23). Os pais adotivos desejam que seus filhos sejam aceitos pela rede social, tornando-os coautores na legitimação da parentalidade e da filiação adotivas. Os pais sentem a não aceitação do filho adotivo pelos grupos sociais como uma agressão, uma rejeição, porque os atinge na sua cadeia genealógica. A sociedade humana é a única que não sobrevive pelos instintos naturais, diferentemente dos outros animais, por isso é vital para a continuidade da espécie humana o laço social. De certa forma, vimos isso quando discutimos totem e tabu em Freud (1913-1914). Talvez esta ideia do aliar-se para sobreviver possa ser usada para entendermos o caráter inadmissível da segregação, do preconceito para com o sujeito, pois receber a rejeição, logo, o afastamento do laço social, é ser atacado em sua sobrevivência.

Pensamos que, nessa rede, a escola possui um lugar importantíssimo para os pais adotivos. Segundo Klein (1923), a escola na vida da criança é um encontro com a realidade. A autora assegura que é na escola que a criança passa do ambiente familiar, que constituía a base de suas fixações e formações de complexos, para um ambiente em que vai conviver com novos objetos e atividades. A nosso ver, a escola tem esse papel agregador, pois representa uma parcela da sociedade. Cabe à escola não permitir que a criança seja marginalizada, nem que ela mesma se marginalize ou se sinta diferente. Portanto, o assunto da adoção deve ser levado até às crianças, já que, ao tratar disso, a escola estará contribuindo para a formação dos sujeitos. Silva (2011) considera positiva a realização de palestras e discussões com o objetivo de promover a inclusão e a 
informação sobre o tema. Ou seja, informar sobre as diferenças sem juízo de valores.

O que diferencia essas famílias com filhos adotivos é a inclusão na cadeia genealógica de um sujeito mesmo sem a conexão biológica. Contudo, fica a questão sobre qual é o valor dado ao biológico, instituindo-o como elemento determinante do ser parente. Para tal discussão, talvez seja necessário entrar no âmbito do social. Isso porque os processos psíquicos não podem ser isolados do contexto sociocultural no qual se produzem.

A partir de um vértice psicanalítico, Cypel (2012) destaca que os aspectos mais preocupantes na sociedade ocidental de nossos dias caracterizam-se pelo domínio da imagem, sem a priorização do ato de pensar, e pela onipotência do virtual. Segundo a autora, "há o predomínio do princípio do prazer sobre o de realidade, na busca da completude narcísica, na intolerância à frustração e à dor psíquica e na dificuldade de acessar o universo simbólico" (p. 57). Acrescentamos a essa ideia o lugar que a sociedade confere à ciência, cujo discurso é tomado como a revelação da verdade absoluta, eliminando-se o caos e a angústia das incertezas, ou ainda o desamparo. A sociedade que anseia explicações e certezas acaba atribuindo um valor narcísico concreto ao código genético, considerando-o como algo inviolável e verdadeiramente único do sujeito.

Conforme relembra Forbes (2011), a sociedade ocidental é filha do Iluminismo, buscando desesperadamente estabelecer um nexo causal aos fatos. O sujeito desta cultura aprende que tudo deve ter uma razão de ser, e caso esta não esteja clara, a falha estará no raciocínio imperfeito. Para Forbes (2011), no entanto, ainda não é possível suportar que somos órfãos de explicações. De acordo com esse autor, ao contrário do dito popular "Freud explica", cabe pensar que "Freud implica", ou seja, implica o sujeito em sua vida, existindo uma instância fora da consciência cujo saber fica escondido e em certo nível inalcançável.

Ainda segundo Forbes (2011), um novo tipo de laço social emerge: o laço do "tá ligado?", o qual não privilegia o entender, mas sim o ser tocado. Este ser tocado significa ser atravessado por outra singularidade e fazer algo com ela. A legitimação desse atravessamento, de outros objetos no sujeito, formaria o novo paradigma do mundo.

Mas o que isso teria a ver com os vínculos familiares? Dentro dessa perspectiva, propomos pensar que o ser tocado é fundamental para o se ligar, 
promovendo um elo entre estranhos (sujeitos singulares) e possivelmente formando, a partir desse encontro de singularidades, o já mencionado terceiro elemento de Eiguer (2012). Entendemos o deixar-se tocar, o ser atravessado pelos afetos e pela ocorrência de identificações, como sendo os elementos norteadores das novas relações, principalmente as familiares. Conforme Forbes (2011), deveríamos habitar esse novo mundo, o do laço do "tá ligado", legitimando as singularidades. Para proceder a essa legitimação das singularidades, o autor acentua que são necessários dois movimentos na época atual: a invenção e a responsabilidade. $\mathrm{O}$ inventar corresponderia à forma singular de ocupar o seu lugar na vida, tendo coragem de expor essa singularidade e responsabilizando-se por ela.

A respeito da legitimação das singularidades, lembramos de uma afirmação muito realçada por alguns pais: "Eu gosto dos meus filhos igualzinho". Vemos que o amor pode ser igual, mas as afinidades e a qualidade das relações são variáveis, e estas são apontadas pelos próprios filhos. Forbes (2011) observa que tal afirmação, muito comum nas famílias, de fato não corresponde à realidade relacional, pois o amor é diferente da afinidade, sendo esta última caracterizada por sua multiplicidade no tempo e nas circunstâncias. Para o autor, o mais interessante do amor de um pai por um filho é seu caráter inexplicável, não cabendo pensar em graduações para o mesmo, com alegações de ser maior ou menor por este ou aquele filho, já que, não sendo explicável, não pode ser mensurado. Isso permite ao filho constituir sua identidade e fazer suas escolhas, porque não está em jogo ele ser mais ou menos amado. Paradoxalmente, quanto mais próximas duas pessoas ficam, devido às suas semelhanças e afinidades, mais elas entram em contato com suas diferenças.

Como já ressaltado, o filho, ao mesmo tempo em que representa a continuidade, também reflete a diferença e o limite. E de que modo o filho adotivo representaria a continuidade, o prolongamento da linhagem genealógica? Pensamos que essa continuidade estaria justamente no atravessamento da subjetividade do filho pela singularidade de sua família adotiva, cujos conteúdos afetivos inconscientes serão por ele metabolizados e posteriormente transmitidos. Da mesma forma que o efeito de um livro sobre seu leitor. As ideias impressas, originadas de um estranho autor, tocam afetivamente o leitor, que as leva continuamente em seu acervo psíquico. 
4.

\section{A ADOLESCÊNCIA EM QUESTÃO}

O interesse pela adolescência e por suas contingências é algo notório na sociedade ocidental contemporânea. Vários estudos foram feitos, e muitos outros surgem, ligados às questões específicas dessa etapa do desenvolvimento humano. Podemos afirmar que a adolescência é um constructo historicamente atual, definido em diferentes áreas do saber. Os mais diversos pensadores observaram que o ser humano se defronta com um estado de transição de caráter biopsicossocial, que demarca a fronteira entre ser criança e ser adulto. Áries (1981) afirma que esse constructo é recente dentro de um ponto de vista histórico, tendo sido criado entre o final da Primeira Guerra Mundial e o início da Segunda Guerra Mundial, entre 1918 e 1939.

A palavra adolescência vem do latim ad (a, para) e olescer (crescer), significando o processo de crescimento. Entretanto, também encontra origem etimológica na palavra adoecer. Essas duas origens oferecem os elementos principais desta etapa da vida: “aptidão para crescer (não apenas no sentido físico, mas também psíquico) e para adoecer (em termos de sofrimento emocional pelas transformações biológicas e mentais que operam nesta faixa da vida)" (OUTEIRAL, 2008, p. 4).

Nicoletti (2012) descreve que esse período do desenvolvimento é o momento no qual o jovem integra o que foi vivido na infância, colocando em movimento os investimentos libidinais para a construção de uma nova "imagem de si mesmo". Portanto, ocorre nesse momento uma reatualização da identidade individual, por meio de um processo dinâmico que perpassa diferentes aspectos temporais e atemporais do desenvolvimento.

Emmanuelli (2005) argumenta que o período de transição entre a infância e a idade adulta - iniciando na puberdade e terminando aos 18 ou 20 anos - abrange uma situação complexa, que envolve transformações nas áreas fisiológica, psicológica, cultural e social, que também se correlacionam aos aspectos sociais de uma determinada época. A respeito da passagem pela adolescência, Cerveny e Berthoud (2010) ressaltam que a adolescência deve ser compreendida dentro de 
seu contexto sócio-histórico. Em alguns povos, por exemplo, esse momento pode coincidir com o passaporte para o casamento e a maternidade, enquanto para outros significa uma total dependência da família de origem, concomitantemente com a busca pela independência subjetiva.

Por isso, destacamos que as colocações desenvolvidas referem-se à organização social do Ocidente. Deixamos claro que escrevemos sobre uma parcela específica da população adolescente, cujas famílias têm acesso à educação e à cultura e pertencem a um estrato social mais favorecido da nossa sociedade.

Muitos trabalhos científicos focalizam a adolescência sob nova perspectiva, segundo a qual as vicissitudes dessa fase da vida se desenrolam tanto em nível intrassubjetivo como em nível intersubjetivo. O epicentro das transformações ocorre no nível intrassubjetivo, porém velhas e novas angústias são acionadas no âmbito familiar, provocando fenômenos de transição no funcionamento inconsciente do grupo.

Nicolleti (2012) destaca que o impacto do adolescer para a família não recebe tanta atenção dos estudiosos. Para a autora, tal fato deve mudar nos próximos anos, principalmente com a produção ativa das abordagens de família e casal. Essa mudança se faz necessária na medida em que a adolescência deve ser compreendida como um fenômeno de fronteira, que se instala no "entre": entre o corpo infantil e o corpo adulto, entre o passado e o futuro, entre o sujeito e o grupo familiar.

Buscamos discorrer sobre o adolescer na dinâmica do grupo familiar, valorizando essa perspectiva de entendimento, já que na adolescência as bases estruturais da família são colocadas à prova (LÉVY-SOUSSAN, 2006), o que exige dos membros familiares flexibilidade e continência para se adaptarem às deflexões. Portanto, é importante compreender que o adolescer interfere não somente na vida do jovem, mas também na vida da família, promovendo modificações na sociedade. Conforme assinala Emmanuelli (2005), a mutação é fundamental no processo da adolescência, pois estimula o indivíduo, a família e a sociedade a crescerem. Dentro deste conceito, pensamos que essas transições exijam uma elaboração psíquica nos níveis intrassubjetivo, intersubjetivo e transubjetivo.

No nível intrapsíquico, trata-se de um tempo de crise, durante o qual são desfeitas as formas identitárias infantis, cujo rearranjo representa um ponto de 
deflexão no sujeito, ou seja, um desvio no caminho daquilo que foi constituído para seguir o que a sociedade espera que ele se transforme. Contudo, o propósito é pensar o sujeito do inconsciente como um sujeito do grupo, mantendo a ideia de que os processos individuais acontecem num "entre" sujeitos. De acordo com Puget (2012), o "entre" sujeitos produz uma ruptura, uma descontinuidade, que acarretam a necessidade de se fazer algo inédito na inter-relação. Para a autora, este algo inédito é o "efeito presença", o efeito de estar entre duas ou mais pessoas.

Conforme ressalta Emmanuelli (2005), ao ter que lidar com as movimentações pulsionais impostas pela puberdade, com o reatamento do conflito edípico e com a necessidade de elaborar a separação das figuras identificatórias, ocorre um enfraquecimento das bases narcísicas do adolescente, fragilizando-o psiquicamente.

Pensamos que algo semelhante ocorre também no nível grupal, havendo um rearranjo nos vínculos familiares que contribuem para uma fragilidade narcísica grupal. Emmanuelli (2005) afirma que o desligamento dos primeiros vínculos promove a descoberta da solidão humana, e a elaboração desta abre a possibilidade para a experiência amorosa. A família também se depara novamente com essa solidão, ao sofrer a separação demandada pelo jovem. Contudo, o grau de intensidade da sensação de vulnerabilidade, tanto para o adolescente como para o grupo, está ligado à fragilidade da função continente grupal.

\section{1}

\section{Processos intrapsíquicos do adolescer}

Benghozi (1999) propõe um olhar interessante sobre o processo de adolescer, compreendendo-o não como uma crise, mas como um processo de organização psíquica, devido às possibilidades evolutivas e aos rearranjos que ele proporciona. Sendo assim, entendemos crise, neste trabalho, como um processo crítico no qual ocorre um caos estruturante, que corresponde à evolução da saúde emocional do sujeito.

Ainda segundo Benghozi (1999), pelo fato de o adolescer ser um momento predominantemente de rearranjos narcísicos, há anamorfose da psicodinâmica do sujeito, e as transformações psíquicas deste são representadas por uma mudança de "pele". O autor recorre ao conceito metafórico de Anzieu (1988) sobre o eu 
como um envelope/pele do psiquismo. A anamorfose, proposta pelo autor em questão, diz respeito à vida psíquica individual e grupal.

Para Benghozi (1999), as atitudes do adolescente se instituem dentro do cenário geracional familiar, tratando-se de um "evento" que afeta a família como um todo. $\mathrm{O}$ autor afirma que se esse cenário for rígido, ficará reduzido o espaço de liberdade para a individualidade, criando-se um sentimento de ameaça à integridade das representações simbólicas do grupo. Nesses casos, tudo é vivido como se os adolescentes confrontassem o sistema, podendo fazer do jovem um paciente identificado. Alguns sintomas de filhos adolescentes são expressão da patologia no aparelho psíquico grupal familiar, os quais buscam sustentar os frágeis vínculos afetivos via sintoma. Na literatura existe um consenso sobre a importância da qualidade do ambiente familiar como continente psíquico, influenciando a evolução do processo de mudança. Discutiremos esse ponto posteriormente.

$\mathrm{Na}$ adolescência culminam os paradoxos, como modificação e continuidade na identidade, desligamento dos pais e necessidade deles. A vivência desses paradoxos é conflitante, provocando ansiedade de incompletude e de castração, angústia da perda do objeto e de abandono. O adolescente fragilizado narcisicamente procura evitar a dor psíquica, por meio de acting outs ou defesas primitivas, cuja função é a evasão de pensamento (BENGHOZI, 1999). Pensamos que por isso, Savietto (2010) considera a adolescência como uma situação limite.

Erikson (1971) é um autor muito citado pelos mais contemporâneos, delineando o esclarecimento crucial sobre a fronteira entre o "normal" e o "patológico" na adolescência. O autor em questão considera que a adolescência constitui uma "crise normativa", ou seja, um momento evolutivo que se caracteriza por um processo normativo de estruturação da identidade do indivíduo. É necessário entender que o processo de organização da identidade normal será composto de momentos progressivos e regressivos em relação aos conflitos internos e/ou externos.

Pensamos que o conceito de "mudança catastrófica", proposto por Bion, ajuda nesta reflexão sobre as repercussões da adolescência. Outeiral (2001) argumenta que o termo "mudança catastrófica" aponta para uma conjunção de fatos, os quais aparecem como um aspecto novo na mente, no grupo, ou na 
sociedade. Ou seja, o conceito refere-se ao efeito do novo sobre um padrão estabelecido.

Conforme as analogias de Outeiral (2001), a "mudança catastrófica" seria como um novo descobrimento que "violenta" as concepções de uma teoria preexistente, um revolucionário que "quebra" a estrutura da sociedade. Em acréscimo a esses argumentos, podemos considerar o efeito da adolescência na estrutura do sistema como este novo que desorganiza, que violenta o grupo, mas consequentemente faz amadurecer.

A respeito desse novo, que rompe com o estado de equilíbrio, existem aspectos cruciais que eclodem na evolução da adolescência. Osório (1989) é um dos autores que delinearam de forma clara os principais aspectos psíquicos evolutivos, tais como a redefinição da imagem corporal, a culminação do processo de separação/ individuação, processo que envolve o luto pela perda da condição infantil, a busca de identificações com os grupos de iguais, a assunção de papéis sexuais.

Com relação às modificações do corpo, a vivência é em parte ameaçadora, já que estas tornam inexorável a entrada da criança na condição de adulto. Essas mudanças corporais são processadas psiquicamente como perdas e debilitam o ego, especialmente no prelúdio da adolescência. Uma das possibilidades de elaboração do luto da condição infantil é recorrer à atividade de fantasias conscientes, sonhos diurnos e atividades intelectuais diversas. Outeiral (2008) sublinha que a forma de o adolescente processar os lutos evidenciará as condições de seu funcionamento psíquico, dando indícios de integridade e de saúde. Por vezes, se existir algum grau de comprometimento emocional, o adolescente pode apresentar graves transtornos na relação com o corpo, sentindo-o como algo estranho, invasivo e persecutório

A sexualidade talvez constitua um dos tópicos mais complexos e significativos, já que tem importância tanto para a sociedade como para o mundo interno do indivíduo. A passagem ocorre da sexualidade infantil (bissexualidade) para a sexualidade adulta. Essa passagem é bastante conflituosa para o adolescente, uma vez que remete à questão da ansiedade homossexual. Juntamente com a organização da sexualidade vem a escolha objetal amorosa, compondo o grupo das principais "tarefas" evolutivas da adolescência. 
Para que não haja nenhum prejuízo no autoconceito sexual, a sexualidade do adolescente não deve ser negada, ignorada ou rejeitada pelos pais. De acordo com Cerveny e Berthoud (2010), outra possível consequência dessa alienação dos pais é aumentar os riscos de uma atividade sexual dos filhos de maneira prematura, excessiva ou perigosa. As autoras observam que, nas famílias em que a informação sexual é aberta, fica mais fácil para os adolescentes aceitar sua sexualidade, viabilizando que se estabeleçam limites realistas e sensíveis (p. 91)

Sob o ponto de vista psicanalítico, a vivência da sexualidade está diretamente ligada ao complexo de Édipo, que sofre uma reatualização, mantendo as peculiaridades da infância, mas somadas um novo fator: o amadurecimento do corpo biológico (puberdade). A consolidação de um corpo adulto representa a viabilização das fantasias sexuais passíveis de realização. Isso produz ansiedade e atitudes que envolvem profundamente "o existir" e "o ser" do adolescente (Savietto, 2010).

Outro ponto a destacar diz respeito ao processo de separação/individuação. No estabelecimento da autonomia, os adolescentes ao mesmo tempo em que precisam responsabilizar-se pelas próprias decisões, também devem contar com a orientação dos pais. Contudo, para que isso seja alcançado, Cerveny e Berthoud (2010) pontuam que deve haver uma flexibilidade nas fronteiras familiares, de modo que seja favorável a modulação da autoridade parental.

O adolescente dirá não aos pais a fim de comunicar que tem vontade própria, portanto, uma identidade independente das figuras parentais. O gesto agressivo na adolescência deve ser entendido como a busca do jovem para se assegurar de que existe alguém que o compreende e pode suportar que teste o quanto o outro gosta efetivamente dele (OUTEIRAL, 2008, p. 61).

Nesse processo de individuação, o adolescente tende a se afastar das figuras identificatórias primitivas, mas sua fragilidade egoica promove a busca do senso de pertencimento, que ele encontra no bando de iguais. Esse bando representa a procura de identidades similares, que, unidas, transmitem ao ego uma vivência de "poder" pelo pertencimento grupal (OUTEIRAL, 2008). Dentro do grupo encontra-se uma uniformização, não havendo espaço para a diferença, apesar de o adolescente necessitar intensamente da diferenciação (CERVENY e BERTHOUD, 2010). 
Discorremos sobre o quanto o adolescente se depara com pressões externas e internas, porém poucos autores estudam como tais pressões são vivenciadas pelos adolescentes que são filhos adotivos. Haveria alguma especificidade? Filho (2008) descreve que as crianças adotadas vivenciam a adolescência com mais conflitos, os quais, segundo ele, são resultado do enigma de sua origem. $\mathrm{O}$ autor observou, também, uma relação pouco estudada entre esse enigma e a vivência da sexualidade pelo adolescente.

A sexualidade pode surgir com uma intensidade sintomática nesses jovens, pois está vinculada ao abandono dos pais biológicos, incitando um desejo de procriação como uma forma de reparar o trauma vivido. Dentro desta mesma questão, Levinzon (2000) postula que a grande interrogação da vida do adotado é saber a razão pela qual não foi criado pelos pais biológicos. Mesmo as justificativas e conversas com os pais adotivos não preenchem o vazio dessa incógnita.

Algumas particularidades a respeito desses adolescentes são apontadas pelos teóricos, como a dificuldade em lidar com a curiosidade característica da fase, aparecendo como um sintoma de problema de aprendizagem. Outra igualmente comentada é a dificuldade de estabelecer relacionamentos amorosos estáveis, sendo angustiante para o filho adotivo se perceber desejando o outro, pois teme depender dele e correr o risco de ser abandonado.

$\mathrm{Na}$ literatura encontramos algumas observações sobre a vulnerabilidade da identidade dos adolescentes adotivos e sobre as dificuldades dos pais com o desenvolvimento psíquico dos filhos. Pensamos, portanto, ser mais proveitoso considerar a adolescência não somente pelo foco da psicodinâmica individual do adolescente, mas também sob uma perspectiva que implique o grupo familiar nesta passagem.

\section{2}

\section{0 adolescente e o ambiente familiar na obra de Winnicott}

Ao chegarem à puberdade, meninos e meninas estão psiquicamente constituídos segundo os modelos primitivos. Portanto, existe uma organização preexistente do ego, a qual reagirá às novas investidas do id. Reacendem-se ansiedades primitivas, assim como defesas para lidar com as mesmas (WINNICOTT, 1965; PALHARES, 2008). Nesse sentido, Winnicott (1961) 
afirma que há na adolescência uma repetição da fase infantil, na qual será reeditado o repúdio ao não $e u$, para depois ser possível o estabelecimento de relação com o não eu.

Existem duas frases emblemáticas do autor a respeito dessa reedição das vivências primitivas na adolescência. Apesar de aparentemente opostas, as frases se complementam ao sustentarem a ideia de que "as coisas não são mais o que eram", porém "quanto mais as coisas mudam, mais se parecem a si mesmas" (WINNICOTT, 1965, p. 138). Por mais que o sujeito se desenvolva, as bases primitivas tendem a se repetir.

Conforme destaca Palhares (2008), a adolescência é um tempo de epiderme frágil, de novas leituras em velhas ideias, já que "as velhas identificações caem como plumas, para que outras cresçam e apareçam" (p. 28). Considerando essa reedição das vivências primitivas na adolescência, cabe fazer o desdobramento de algumas formulações essenciais na obra de Winnicott, a respeito do desenvolvimento emocional primitivo.

O pensamento do referido autor tem como base o entendimento do amadurecimento emocional num contexto dialético. O bebê e a mãe formam, ao mesmo tempo, uma unidade e uma separação. $\mathrm{O}$ bebê, com suas necessidades e potencialidades, dependerá da relação com o ambiente facilitador para que seja mantido seu senso de "continuidade de ser". É a partir da integração do ego, cujo processo depende das condições desse ambiente suficientemente bom, que o indivíduo poderá começar a existir, o que lhe possibilitará viver as experiências do id (WINNICOTT, 1950-1955).

O ego e a experiência intersubjetiva começam juntos na relação fusional (mãe-bebê), que só pode ser descrita como dual, dentro da perspectiva de um observador. Neste momento, a mãe deve se adaptar às necessidades do filho, funcionando como seu ego auxiliar. Na fantasia eles formam uma unidade, e a mãe não deve se fazer objetivamente percebida para proporcionar ao bebê a experiência de ilusão, permitindo que essa não diferenciação entre o eu e o não eu seja estruturante (DAVIS e WALLBRIDGE, 1982).

É nessa relação fusional que o impulso do amor primitivo será despertado, com o propósito de buscar um objeto, sendo caracterizado por Winnicott como potencialidade agressiva do bebê. À medida que o lactante fortalece seu ego, a mãe passa a desiludi-lo e a mostrar que existe uma realidade externa a ele. A 
apresentação do mundo externo é uma oposição ao mundo subjetivamente concebido pelo bebê, compelindo-o a ir buscar o objeto e, assim, satisfazer sua raiz agressiva/ de motilidade.

A agressividade surge pelo processo natural de maturação, cujo elemento é a motilidade (WINNICOTT, 1950-1955). Segundo os estudos de Ferreira (2008), essa motilidade estaria vinculada "ao movimento de expansão e de expressão do self' (p. 77), explicitada no gesto espontâneo do bebê, o qual o leva a descobrir os objetos do mundo externo. Tais objetos formam uma oposição adaptativa a esse movimento, promovendo o processo de reconhecimento do não eu.

Winnicott (1950-1955) sustenta que o indivíduo precisa da oposição para encontrar a raiz da motilidade, cujo objetivo é a busca de algo para empurrar/ir ao encontro de, descobrindo e redescobrindo o mundo externo ao longo da vida. Isto é sentido como uma experiência satisfatória quando o ambiente "se intromete de modo consistente" (p. 298). O autor propõe que a agressividade leva o bebê a necessitar de um objeto externo, sendo diferente da busca de um objeto apenas para satisfazer seus impulsos.

Por meio do papel de oposição, executado por ambiente consistente, sem invasão nem retaliação, a agressividade poderá ser vivida como parte do processo criativo, o que permitirá ao bebê criar seu mundo, tendo a ilusão de sua onipotência. Aos poucos, o objeto subjetivamente concebido será destruído para que possa ser percebido objetivamente.

Em $O$ uso de um objeto, Winnicott (1969) ressaltará que o impulso do amor primitivo é uma combinação de amor-conflito, pois tem uma potencialidade destrutiva. De acordo com a terminologia do autor, o bebê é impiedoso justamente porque ainda não percebe os efeitos de sua destrutividade sobre o objeto. A agressividade inicial do bebê aparece, primeiramente, sem a intencionalidade de destruir o objeto, por pertencer a uma etapa anterior à de concernimento.

Havendo o concernimento, configura-se um segundo momento, no qual a destruição torna-se uma responsabilidade do ego, surgindo o temor à retaliação. A criança passa a se preocupar com os efeitos de seus impulsos sobre a mãe, e também começa a perceber as experiências de seu próprio self, construindo uma confiança em si própria e na sobrevivência do objeto.

Conforme afirma Winnicott (1950-1955), “na saúde é possível a criança dar conta da culpa, e com a ajuda de uma mãe viva e atenta, tornar-se capaz de 
descobrir um anseio pessoal por dar, construir e reparar" (p. 291). Assim, a agressividade terá seu valor social, sendo concebida por Winnicott (1950-1955) como fundamental para o indivíduo e, também, para a sociedade. O autor enfatiza que o perigo para a sociedade é a repressão da agressividade, e não a sua existência nos indivíduos. Com a sobrevivência do objeto, o indivíduo, sem medo da retaliação, poderá manter sua agressividade dentro de si, acreditando que seu ego poderá sobreviver à mesma.

Especificamente, a agressividade/motilidade começa a operar nos primórdios do desenvolvimento do ego, sendo depositada $x$ por cento nas experiências do id, por meio de uma fusão. O restante de motilidade não fusionado ao potencial erótico, que Winnicott (1950-1955) representa por $100-x$ por cento, será usado em outros aspectos puramente motores, determinando a singularidade do potencial de agressividade existente em cada indivíduo. As falhas adequadas da mãe suficientemente boa serão importantes para que não haja uma total satisfação dos impulsos do id. A partir dessa parcial insatisfação, a raiz motora se realiza ao entrar em ação na busca pelo objeto e, quando o encontra, constitui e reconstitui o seu senso de existência.

Todavia, se as falhas forem invasivas, não permitindo ao bebê o senso de continuidade de ser, serão desencadeadas "reações" à intrusão do mundo externo. O bebê sentirá que precisa proteger ainda mais o núcleo do self e desenvolverá uma casca defensiva (falso self). Assim, ele reconhecerá sua existência pelo fato de "não ser encontrado" (WINNICOTT, 1950-1955).

Outro efeito do ambiente invasor é o indivíduo não desenvolver a capacidade de usar o objeto ao longo de sua vida. O conceito de usar é definido por um sentido específico, que corresponde à ação de aproveitar, de apropriar-se, de tomar posse daquilo que o ambiente pode oferecer (BITTENCOURT, 2004). Tudo isso coloca a criança rumo ao uso do objeto, pois o bebê destrói o objeto concebido subjetivamente e passa a perceber o objeto externo, formando-se assim um dos paradoxos winnicottianos - destruir para construir (BITTENCOURT, 2004). Consequentemente, a criança realiza a diferenciação entre a fantasia patrocinada pela onipotência e a realidade externa, passando a qualificar sua existência como independente.

No ambiente invasor, esse desenvolvimento não será possível, pois o bebê não poderá vivenciar a experiência de possuir, de se diferenciar como algo 
destrutivo ao objeto. Assim, não será possível a conquista da ambivalência em relação ao objeto, ou seja, amá-lo e também odiá-lo, pois isso significaria a aniquilação do mesmo. Nestes casos, tanto o estabelecimento da diferenciação eu e não eu, como a constituição do limite entre a fantasia e o mundo externo ficam comprometidos.

Winnicott (1969) diferencia relacionar-se de usar, e concebe o primeiro como uma experiência isolada do indivíduo, entendendo-a como uma concepção ainda subjetiva do objeto, impregnada pelo feixe de projeções. $\mathrm{O}$ autor esclarece que para se atingir o uso do objeto, é preciso estabelecer a mudança da onipotência para o princípio de realidade, e sentir o objeto como real, pertencendo à realidade compartilhada.

No adolescente, este processo de mudança da ilusão de onipotência para o estabelecimento da realidade compartilhada é revivido. Ao mesmo tempo em que se vive uma dependência regressiva, deseja-se estabelecer uma independência desafiadora. Ou seja, o jovem quer a liberdade, mas se sente abandonado se a família sucumbe a esse seu desejo (OUTEIRAL e ARAÚJO, 2001). Assim, os adolescentes oscilam entre um vir a ser amparado por suas próprias pernas e posicionamentos e um voltar aos padrões de dependência, a ponto de agirem como bebês (PALHARES, 2008, p. 26).

Para atingir a totalidade de um ser sustentado por si mesmo, o verdadeiro self, é preciso lançar mão da agressividade. Ou seja, a busca de uma individuação é permeada pela fantasia inconsciente de que crescer é um ato agressivo com o ambiente (OUTEIRAL e ARAÚJO, 2001; OUTEIRAL, 2008). A agressividade do filho coloca à prova a capacidade dos pais de fazerem face à sua destrutividade individualizante. Será necessário que os pais abdiquem da retaliação e procedam a uma contenção das atitudes dos adolescentes. Isso corresponderia à aplicação da capacidade de usar o objeto, a qual é atingida pelas "experiências que envolvem a sobrevivência do objeto" (WINNICOTT, 1968, p. 186).

O grupo familiar deve sobreviver aos ataques e suportar, por exemplo, que o investimento libidinal passe das figuras parentais para as figuras sociais. Esse deslocamento, quando sustentado pelo núcleo familiar, permite a consolidação do eu e a individuação do jovem. Assim, neste período de passagem, o papel da família torna-se fundamental para a promoção de saúde emocional. Quando os pais são incapazes de resistir à destrutividade e à separação dos filhos, por se 
sentirem ameaçados e impotentes, eles provocam a fantasia no adolescente de que os efeitos desses movimentos são irreparáveis, intensificando o sentimento de culpa inconsciente pela destruição do objeto (MARTY, 2006).

Para o jovem, o imaginário é sentido como mundo real, por isso ele precisa de uma resposta continente dos pais, de modo a converter sua fantasia agressiva em ação criativa. Assim, a fantasia hostil perde a força onipotente e seu próprio self poderá sobreviver ao ódio, passando o adolescente a vivenciar seus gestos espontâneos sem ameaça.

Segundo Winnicott (1961), é inviável a organização dos conteúdos psíquicos sem um ambiente facilitador que os reconheça e acolha. A contenção, pelo ambiente, das ansiedades e dos impulsos dos jovens gera uma confiança na relação com o mundo, sem que seja preciso desafiá-lo para eles se sentirem existindo.

$\mathrm{O}$ autor expõe quatro necessidades principais exteriorizadas pelos adolescentes. A primeira corresponde à necessidade de evitar soluções falsas; a segunda é a de se sentirem autênticos; a terceira diz respeito à necessidade de desafiar e a quarta, a de ser antagonista da sociedade (CAMPOS, 2011; WINNICOTT, 1965).

A necessidade de evitar soluções falsas é considerada um dos elementos significativos para o sujeito atingir o senso de autenticidade. Essa necessidade leva o adolescente a uma moralidade, atacando ferozmente qualquer elemento que lhe pareça falso. Campos (2011) aponta que essa necessidade também existe na criança e nos esquizofrênicos. Tal associação é interessante, pois remete à existência de um aspecto comum aos sujeitos pertencentes a esses três grupos: a predominância das ansiedades e defesas primitivas, seja como uma reatualização (no adolescente), ou configurada como uma patologia (na esquizofrenia).

Nas palavras de Winnicott (1965), “o adolescente busca uma cura imediata, mas ao mesmo tempo rejeita todas as curas que encontra, pois detecta em cada uma delas um elemento falso" (p. 122). Como foi descrito, os adolescentes travam uma luta para se sentirem reais, porque as identificações parentais ficam em suspenso, o que leva a uma vivência de irrealidade de ser. A busca é o estabelecimento da identidade, e para isso eles não permitem ser encaixados em um papel predeterminado, ao mesmo tempo em que não sabem quem são, nem o que virão a ser (DAVIS e WALLBRIDGE, 1982). 
Apesar de ser próprio do adolescente viver em grupo, Winnicott (1965) destaca que, por essência, o jovem é um ser em isolamento. Isolamento como o vivenciado na infância com relação ao repúdio do não eu. Trata-se, pois, de algo pertencente à natureza da fantasia de um objeto subjetivamente concebido, mantido dentro do controle onipotente. $\mathrm{O}$ andar em grupo nada mais é do que participar de um agregado de seres isolados, que tentam ser a partir da identidade grupal. Os membros se assemelham num "bloco" unívoco (gangue/tribo), cujo elo é a uniformização, não havendo espaço para a diferenciação. $O$ curioso é que o grupo, ao mesmo tempo em que representa a possibilidade de diferenciação, simboliza a "fuga de casa", os modelos parentais abandonados.

Palhares (2008) faz reflexões interessantes a respeito desse ponto, questionando se seria possível considerar essa característica do grupo adolescente como uma reedição da capacidade de estar só na presença de alguém. Para a autora, dessa forma o grupo é vivido como uma extensão de cada jovem, cuja uniformização/ estar só permitiria a cada um experimentar a si mesmo sem intrusões.

Pensamos que esse refúgio nos grupos para evitar as intrusões, proposto por Palhares, pode corresponder à outra reedição, dentro deste contexto: “quanto mais as coisas mudam, mas se parecem a si mesmas". Tal refúgio abarcaria o desejo de encontrar um novo (o mesmo) ambiente facilitador. Na verdade, Winnicott (1965) sugere que, para o adolescente, os novos círculos funcionam simbolicamente como o colo materno.

A respeito do complexo de Édipo, esse autor ressalta a importância de uma terceira figura apresentar-se ao filho, pois, caso contrário, duas alternativas podem se instalar: a criança ser engolida ou afastar-se violentamente dos pais. Comentamos esta ideia para destacar que podemos conceber o funcionamento simbólico dos grupos, dos novos círculos, como o colo materno, mas também como um terceiro elemento estruturante. Pensamos que o grupo simbolizaria essa terceira figura, que quebra a fusão entre pais e filhos, de modo a viabilizar a individualização, a organização da singularidade do filho. A família vira um corpo, e o grupo representa a quebra, favorecendo a singularidade.

Em suma, se no passado a dependência resultou em confiabilidade no ambiente e senso de continuidade do ser, é possível na atualidade desafiar e confrontar, atacando o ambiente para alcançar a independência, sem deixar de ter 
pai e mãe por perto (PALHARES, 2008, p. 29). O adolescente reivindica que o adulto assuma seu papel de adulto integrado, capaz de encará-lo e de resistir a seus ataques (PALHARES, 2008, p. 27). Havendo a sobrevivência do vínculo afetivo-familiar - sem ruptura e sem vingança -, a saúde é alcançada, pois ocorre a conciliação entre opor-se, confrontar, odiar e amar, aproximar-se, usar o objeto com a parte contestada (não aniquilada) (PALHARES, 2008, p. 30).

A reatualização do processo de uso do objeto na adolescência do adotado pode despertar a desconfiança da "continuidade" dos vínculos, considerando que o vínculo primitivo com a mãe biológica foi rompido. Nestes casos, talvez a sobrevivência dos pais na passagem do filho pela adolescência vá além do estabelecimento do eu e não eu, da diferenciação entre fantasia e realidade compartilhada. Caso essa desconfiança esteja incluída neste contexto familiar, talvez haja a necessidade de sedimentar o senso de pertencimento à família adotiva e, portanto, a vivência de sentir-se amado. Para isso é necessário que o adolescente possa sentir ódio e que seus pais também suportem esse ódio. Estes devem poder odiar seus filhos, sem na retaliação e sem que isso seja vivido como uma ameaça ao vínculo parental e de filiação. Segundo Winnicott (1947), a mãe odeia o seu bebê por inúmeras razões, entre as quais o fato de ele não ser uma concepção subjetiva dela, de interferir em sua vida privada e de ele tratá-la impiedosamente como uma escrava. Sendo assim, toda mãe deve ter capacidade de sobreviver mentalmente a seu ódio e ao ódio de seu filho, sabendo diferenciar a fantasia da realidade de uma retaliação.

Em pesquisa sobre crianças e adolescentes adotivos em amostras clínicas e não clínicas, Lee Fu e Matarazzo (2001) constataram que alguns profissionais sugerem existir a prevalência de atendimentos aos adolescentes e às crianças adotivas nos serviços de saúde mental. As autoras questionam a razão disso, uma vez que a família adotiva é supostamente uma oportunidade favorável para a vida da criança sem lar. Elas verificaram que em determinadas famílias marcadas pela infertilidade do casal, haveria grande intolerância e ansiedade com relação à criação dos filhos adotivos, por conta do patrocínio da idealização. Talvez, elas não tenham considerado a ambivalência desses pais, da existência do amor e do ódio pelo filho adotivo, como por exemplo, pelo filho adotivo trazer a lembrança do luto de não poder gerar. As pesquisadoras constaram que esses pais estariam excessivamente preocupados com as queixas e os comportamentos dos filhos, 
procurando com mais frequência os serviços de atendimento clínico. E se os pais ficam ansiosos, podemos afirmar que, dificilmente poderão oferecer a seus filhos uma continência para os conflitos adequados à fase que esses estão atravessando.

\section{3}

\section{A família adolescente}

Como explanamos, Winnicott deu extrema importância ao ambiente familiar na passagem da adolescência. Mostramos que em nenhum momento, ao desenvolver sua teoria sobre os adolescentes, ele desconsiderou a influência dos pais na experiência emocional dos filhos nessa fase da vida. Com base nesse autor, defendemos que a participação do ambiente familiar constitui um aspecto fundamental para que transcorra suficientemente bem o adolescer. Mas como a família é afetada pelo adolescer dos filhos? Como enfrentar os desafios desta etapa da vida? Para tentarmos encontrar respostas a essas questões, pensamos ser importante discorrer, primeiramente, sobre o ciclo de vida.

O modelo de ciclo vital é construído a partir de um conjunto composto por acontecimentos específicos, ou etapas cruciais, pertencentes ao desenvolvimento da vida em família (PIRES, 2008). A cada nova etapa quebra-se a estrutura familiar existente provocando mudanças, que exigem do grupo capacidade de adaptação e potencialidade para reorganizarem regras, papéis e representações psíquicas. Devido à predominância de rupturas específicas, o modelo de ciclo vital, seja individual ou familiar, está ancorado na ideia de crise. Cerveny e Berthoud (2010) acreditam que essa visão de crise leva as pessoas a associarem crise a algo não produtor de saúde. Tendo em vista essa qualificação negativa da palavra crise, as autoras substituíram tal palavra por passagem, buscando enfocar o caráter mutativo de cada etapa do ciclo.

Falar em mutação significa desencadear rupturas. Contudo, para que essas rupturas não representem um colapso nos vínculos, os membros do grupo precisam manter algo pertencente à antiga organização. Assim, é possível sentir a sobrevivência da identidade grupal, mesmo com a eclosão das transformações. Considerando essa necessidade de algo se manter para a preservação da identidade grupal, Pires (2008) afirma que o processo do ciclo vital demanda a concomitância da capacidade de estabilidade e de flexibilidade. Dessa forma, é 
possível enfrentar o sofrimento diante da falta do antigo, que já é o conhecido, e da presença do novo, que fica como o enigmático.

Em sua experiência clínica com famílias, Magalhães (2009) deparou-se frequentemente com conflitos familiares "desencadeados por mudanças evolutivas do ciclo de vida da família ou por acontecimentos que envolvem uma reestruturação mais ampla na psicodinâmica familiar" (p. 210). A demanda conjunta de psicoterapia de família nestes momentos cruciais, como, por exemplo, a adolescência, ilustra o quanto é difícil a transformação da dinâmica e do psiquismo familiar. Em alguns casos, haverá o sentimento de colapso dos vínculos, se o grupo não for capaz de se reorganizar diante do impacto dessas desorganizações estruturantes.

Cerveny e Berthoud (2010), a partir dos estudos com famílias na passagem pela adolescência, resolveram denominá-las de família adolescente. As autoras justificam essa nomeação como forma de delinear, mais precisamente, a adolescência no ciclo de vida familiar. Elas observam que, neste momento específico, existe tanto a experiência dos filhos, da transição e das mudanças em direção à idade adulta, como a dos pais, ao reviverem sua própria adolescência.

Outeiral (2008) também segue essa linha de pensamento, mas oferecendo uma compreensão psicanalítica sobre os processos psíquicos em jogo. $\mathrm{O}$ autor afirma que o acompanhamento familiar ao adolescente significa, por vezes, ser inserido na confusão psíquica vivida por este. Isso ocorreria por meio das identificações projetivas. $\mathrm{O}$ autor realça a importância de estarmos atentos à intensidade desse contágio, afirmando serem ingênuos aqueles que desconsideram os adultos nesta passagem.

A partir das ideias de Outeiral, podemos entender a afirmação de outros autores de que o grupo familiar inteiro "adolesce" junto. Dentro da perspectiva psicanalítica, isso se daria devido ao mecanismo de identificação projetiva. Esse mecanismo de defesa é primitivo, ocorrendo desde quando o bebê projeta na mãe seus conteúdos internos, em busca de comunicação e entendimento. Os pais, contagiados por seus filhos, talvez sejam levados a entrar em contato com suas angústias mais profundas, sendo importante usar esta forma de comunicação para entender seus filhos. Dessa maneira, são reativados nos pais seus próprios elementos adolescentes. 
Sobre a crise familiar na adolescência, Cerveny e Berthoud (2010) se depararam com o não reconhecimento da existência de uma crise familiar por parte das pessoas pesquisadas. As autoras compreendem que a caracterização da família adolescente como problemática pertence ao imaginário social, pois essas famílias revelaram-se em melhores condições do que o senso comum supõe. Como justificativa para a discrepância entre os dados coletados e o que é dito pela sociedade e a literatura, elas apontaram o fato de se tratar de famílias que não buscam ajuda psicológica para problemas mais complexos.

Cabe aqui, após esses dados, reforçarmos a ideia da existência de uma gradação de crise psíquica grupal. Essa gradação na crise/passagem, que oscila entre uma maior ou menor promoção de saúde, depende dos recursos emocionais da família, para suportar as transformações, os sentimentos e os mecanismos de defesas despertados. Imaginamos que quanto maior for a promoção de saúde familiar, menor será a vivência consciente abalo nos vínculos, na passagem pela adolescência.

Os pais também podem ser afetados de outra maneira, como, por exemplo, serem acometidos por uma inveja da juventude e da vitalidade transbordantes na adolescência de seus filhos. O adolescente fala do futuro, e falar do futuro é falar de esperança, e para eles é como se tudo fosse possível, enquanto para os pais não é bem assim. Até mesmo em relação à sexualidade, o adolescente envolve-se ora com um, ora com outro. Os pais já não desfrutam dessa liberdade de uma forma tão simples, até mesmo devido ao declínio do desempenho físico (OUTEIRAL, 2008).

Isso justificaria, por exemplo, que alguns pais se vistam como adolescentes, que sintam insatisfação não só com a aparência física, a ponto de mudá-la, mas também com os próprios hábitos. Outeiral (2008) acredita que muitas crises conjugais, as chamadas "crises de meia-idade", podem ser desencadeadas pelo ingresso dos filhos na adolescência. Cerveny e Berthoud (2010) também discorrem sobre a crise dos pais. Segundo elas, nos relatos dos próprios pais existe a preocupação com a aparência, o receio da velhice e o temor das perdas, levandonos a considerar que essa passagem é complexa tanto para eles como para seus filhos.

A renegociação da autonomia e da independência demanda mudanças estruturais nos papéis familiares, que envolvem pelo menos três gerações de 
parentes (CERVENY e BERTHOUD, 2010). Conforme descrevemos, muitos fatores psíquicos embasam o adolescer do grupo familiar, despertando aspectos adolescentes tanto nos pais quanto nos irmãos mais moços. Todos, identificados com o adolescente, passam a apresentar (em maior ou menor grau) vivências emocionais correlacionadas a este momento específico.

Durante esse processo, a família procura alterar alguns padrões de relacionamento. Para que a família adolescente mude esses velhos padrões, é preciso flexibilizar as fronteiras familiares, com vistas a incluir os elementos produzidos pela independência, como, por exemplo, a convivência com grupos extrafamiliares. É frequente a perda da confiança do adolescente no conhecimento dos pais, e estes devem entender e acolher essa mudança de olhar dos filhos. Os pais são questionados sobre seu lugar no espaço familiar, sobre seus limites e suas condutas.

$\mathrm{Na}$ pesquisa que mencionamos realizada por Cerveny e Berthoud (2010), um dos dados obtidos em família adolescentes foi que as mães denunciavam que estes quase sempre as chamavam de ridículas, e por isso precisavam manter-se jovens, até para acompanhá-los. Isso se expressa, às vezes, na adoção de moda jovem, na troca de peças com as filhas, na preocupação com a aparência, procurando ser mais esbeltas e cuidadas. Quanto aos pais, cabe se defrontarem com a voz mais grossa do filho, com o ensinamento do uso do aparelho de barbear, e com o olhar crítico desse filho sobre seu emprego, seus trajes, seu carro, entre outras aquisições.

Cerveny e Berthoud (2010) encontraram outros dados interessantes. As famílias adolescentes apontaram, em suas respostas, que a maior meta familiar era oferecer estudos de boa qualidade para a formação profissional dos filhos. Do ponto de vista das autoras, essa valorização dos estudos coincide com os valores da classe média brasileira. Com relação às práticas dessas famílias adolescentes, os três assuntos mais evitados nas conversas entre eles são: morte (40\%), doenças (31\%) e sexo (16\%). Estes dados encontrados pelas pesquisadoras sobre os assuntos evitados pelas famílias devem ser aqui realçados, como um resultado muito ilustrativo da dificuldade de encarar a condição humana de finitude pelos sujeitos. Para entendermos de modo mais amplo estes dados, os quais consideramos relevantes dentro do seio familiar, primeiramente, acreditamos ser pertinente discorrer sobre os valores atuais da sociedade ocidental contemporânea. 
Savietto (2010) caracteriza a sociedade ocidental atual pela fraqueza do poder e da ordem simbólica, assim como se tornaram aspectos inerentes à mesma a precariedade, a instabilidade e a insegurança. Para a autora, a composição dessas características contribui para a existência de uma intensificação na revivência do desamparo na adolescência. Como resultado disso, ela constata a incidência de passagens ao ato como recurso predominante do funcionamento psíquico do adolescente. Não pretendemos nos estender neste debate, a respeito dos novos valores caros às sociedades ocidentais contemporâneas, devido à amplitude do mesmo. Contudo, devemos pontuar a forte influência da mídia na massificação de valores das famílias e, portanto, favorecendo a disseminação de um culto ao espetáculo, à imagem e ao instantâneo, não havendo espaço para a vivência da dor e da falta (os buracos/ a castração).

Podemos pensar que a vivência da dor e da falta não são questões existenciais fáceis para o ser humano em nenhuma época, até porque, estão na ordem da castração, da constatação da impossibilidade da onipotência. Porém, parecem ainda mais inadmissíveis na atualidade. Observamos na pesquisa de Cerveny e Berthoud (2010) que os três assuntos mais evitados pelas famílias, de certa forma se remetem à dor e à falta (o buraco/castração): morte (40\%), doenças (31\%) e sexo (16\%). A sexualidade, por exemplo, nos remete ao desamparo, na medida em que a entendemos, do ponto de vista psicanalítico, como uma noção ligada às possibilidades e aos limites da representação, da simbolização da força pulsional.

Savietto (2010) resume que a experiência do desamparo vincula-se à ideia de insuficiência do aparelho psíquico em dar conta do excesso de excitação pulsional. Portanto, o desamparo determina um estado mental, no qual o sujeito encontra-se inundado por um excesso de excitações, as quais ultrapassam a capacidade de simbolização. O adolescente vive esse desamparo ao se perceber diante da ativação de novos aspectos pulsionais provocados pela transformação de seu corpo infantil para a genitalização.

A morte e a doença também nos levam a este desamparo diante do excesso pulsional e do limite da simbolização. Para compreendermos mais estas duas questões, nos valemos das formulações do filósofo francês contemporâneo Ferry (2010), sobre o significado da morte para a existência humana. Ele descreve que o ser humano, diferentemente de um ser divino, é mortal, portanto finito/limitado no 
espaço e no tempo. Distintamente dos outros animais, o homem se singulariza pela consciência de sua finitude, compreendendo que irá morrer, bem como seus semelhantes. Este conhecimento não passa despercebido. A interrogação sobre a finitude permanece latejante, justamente pelo caráter insensato e insuportável de viver sem objetos amorosos ou perder a própria vida. Daí muitas pessoas recorrerem à religião, a fim de buscar a salvação da alma, a infinitude em um plano imaterial.

Ferry (2010) nos alerta para a real condição da existência humana e para o quanto esta é frustrante a todos. Ele pontua que a frustração com relação à realidade da própria morte vai muito além da simples constatação do "fim da vida", da parada impiedosa da nossa existência biológica. $\mathrm{O}$ autor sugere que o tormento da morte é fazer o homem ter que conviver com o irreparável e seguir em frente, refletindo sobre o que deve fazer com sua curta vida.

Desse modo, fundamenta-se a angústia primordial humana, pelo temor ao contato com o irreversível (o sentimento de mortalidade). Ou seja, para o filósofo, o insuportável é ter que conviver com o "nunca mais", é deparar-se com o fato de que a vida se apoia naquilo que nunca mais poderemos reencontrar. Ferry (2010) formula que nós vivemos quase toda a nossa vida entre lembranças e projetos, entre nostalgia e esperança. Um dos projetos se configuraria na procura de uma morada pertencente à ordem do "para sempre".

Freud (1919) também desenvolve a ideia do terror ao nunca mais, no texto $O$ estranho, a partir da noção do duplo. A ideia do duplo corresponde a uma invenção defensiva do ego para ir contra a sua própria destruição. A duplicação do ego ofereceria inicialmente a ilusão da infinitude, salvaguardando o narcisismo. O desejo de ter um filho pode ser entendido como o fenômeno do duplo, o desejo de duplicar-se ao transmitir o nome, o seu narcisismo, aplacando o buraco da morte.

As conceituações de Money-Kyrle (1978) complementam as ideias abordadas acima. Segundo o autor, existem três obstáculos emocionais que precisam ser ultrapassados para constituir um aparelho psíquico pensante. O primeiro é reconhecer a dependência que a vida tem da generosidade dos objetos. O segundo é reconhecer a natural exclusão da relação sexual parental, portanto, da capacidade criativa dos pais de se juntarem e conceberem uma criança. $\mathrm{O}$ terceiro obstáculo é reconhecer a inevitabilidade da morte, que é imposta ao ser humano contra a sua vontade, reconhecendo ainda que os impulsos destrutivos foram 
dirigidos tanto aos objetos maus quanto aos bons. $\mathrm{O}$ autor salienta que todos os posteriores atos de reconhecimento dependerão de como foram vividos esses primeiros e das dificuldades que foram registradas primitivamente. Ele ressalta que todos os sujeitos viveram dificuldades de algum nível nesses obstáculos.

Ainda segundo Money-Kyrle (1978), uma das dificuldades de reconhecer que a vida depende dos objetos está relacionada à dura impossibilidade de usufruílos para sempre. "A capacidade para lamentar, ou para sofrer a perda, e a capacidade de lembrar o objeto perdido estão inseparavelmente ligadas. Sem a memória não pode haver luto e sem o luto não pode haver memória” (p. 457). Somente com o registro da existência do objeto e de sua perda, promotora de uma falta, é que será possível a organização de um ego criativo, produtor de pensamentos, de construções e de reconstruções.

Agora como pensar estes obstáculos emocionais nas famílias e nos adolescentes, imersos em uma cultura na qual existe o clamor a satisfação imediata, e a incessantemente busca de suprimir a dor? Savietto (2010) nos responde que a consequência disso é a incitação de saídas de caráter imediatista e absoluto, levando o sujeito às passagens ao ato. Os adolescentes de nossa época, segundo a autora, expressam seu sofrimento, predominantemente, por meio do registro do ato, da convocação do corpo, supondo uma precariedade no que concerne aos mecanismos de simbolização.

A adolescência é uma fase que ilustra o quanto o luto, o "nunca mais", faz parte do desenvolvimento do sujeito. Contudo, se não houver espaço para poder sofrer e perder, conforme postula Money-Kyrle (1978), não haverá possibilidade de organizar um ego criativo, produtor de pensamentos. $\mathrm{Na}$ adolescência vivências do passado se atualizam com força, como a vivência de sedução pelo complexo de Édipo revivido, ou a perseguição por parte dos objetos primitivos (internos), contribuindo muito para que o sujeito adolescente se sinta perseguido por seus pais (Savietto, 2010). Por outro lado, alguns aspectos do passado são perdidos, como o corpo infantil que dá lugar ao envelhecimento, remetendo o sujeito adolescente à sofrida conscientização relacionada à sua própria finitude. Julgamos que estas considerações sejam importantes para entendermos que na própria adolescência, pais e filhos, lidam mais uma vez com a finitude e com o desamparo, de uma forma viva e colorida por questões específicas. Promovendo dessa maneira, um intenso abalo nas bases narcísicas de todos os envolvidos. 
5.

\section{ESTUDO DE CAMPO}

Neste estudo procedemos a uma investigação qualitativa com o objetivo de compreender a vivência de pais adotivos diante da parentalidade e da filiação no período da adolescência de seus filhos adotivos. Conforme foi exposto, desenvolvemos a fundamentação teórica a partir de três eixos temáticos, sendo eles os processos psíquicos de parentalidade e de filiação, as vicissitudes da adoção e a psicodinâmica na adolescência. Esse referencial teórico respaldou a construção do "roteiro invisível" (Anexo I) para a composição das entrevistas semiestruturadas, bem como para a compreensão dos dados obtidos.

Ao avançar pelo caminho da pesquisa de campo, nos deparamos com algumas dificuldades, as quais serão descritas a seguir, para uma completa compreensão da configuração final do estudo. A primeira diz respeito à razão de termos restringido nossa pesquisa à vivência dos pais. Primeiramente, tínhamos pensado em também entrevistar os filhos adolescentes, de modo que a vivência deles pudesse ser estudada e complementasse a dos pais. Contudo, na efetivação do estudo piloto nem um voluntário se apresentou, havendo, até mesmo, uma recusa quando convidamos um adolescente a responder à pesquisa. Entendemos tal desinteresse como um dado significativo, que deixava uma incógnita: os adolescentes não queriam falar, ou seus pais é que não queriam deixá-los falar?

Em cinco das dez entrevistas realizadas, os pais disseram que seus filhos passaram a não querer falar sobre a adoção quando adolescentes, assunto que naturalmente era trazido durante a infância. Esse dado nos fez pensar que talvez exista mesmo algum tipo de resistência, por parte dos adolescentes, a tratar do assunto, indicando uma possível explicação para o fato de não termos conseguido entrevistá-los.

Portanto, neste estudo, tivemos que lidar com a limitação de entrar em contato apenas com o imaginário e as fantasias dos pais. Isso é algo que não deve ser esquecido. Ou seja, que estamos lidando com o discurso de pais, que apreendem a realidade externa a partir de sua realidade interna, compreendendo as situações da exterioridade pelo colorido de seus conteúdos inconscientes. Pensamos que este seja um dos pontos vulneráveis desta pesquisa. Mas que só 
seria crítico, caso tivéssemos a pretensão de colocar o discurso dos pais como a realidade do adolescente, a realidade em si.

\section{1.}

\section{Sujeitos}

A seleção de sujeitos para as entrevistas foi realizada ao longo de todo o ano de 2012. A fim de encontrar sujeitos interessados em participar da pesquisa, efetuamos contatos prévios com pessoas que atuam na área da adoção, principalmente coordenadores de grupos de apoio à adoção, devido à extensa rede social que compartilham.

Cabe aqui descrever que os grupos de apoio à adoção são coordenados, na maioria das vezes, por pais adotivos e profissionais de diferentes áreas, os quais trabalham voluntariamente no preparo de pessoas postulantes à adoção e no acompanhamento de pais adotivos. Além disso, os grupos possuem o objetivo de conscientizar a sociedade sobre a nova cultura da adoção (ANGAAD, 2011).

Com a intenção de ampliar a divulgação, informamos amigos e conhecidos sobre nossa pesquisa. Para todas essas pessoas, foi enviada uma carta on-line (Anexo II) , apresentando o referido estudo e solicitando a indicação de possíveis participantes. Nessa carta, constam o objetivo e os temas da pesquisa, assim como orientações para a realização da mesma, os dados do pesquisador e a sugestão de que a carta on-line fosse repassada a outros conhecidos, de modo que a divulgação atingisse um maior número de pessoas. Os sujeitos voluntários deveriam entrar em contato com a pesquisadora, a fim de ser marcada a entrevista.

No projeto inicial, tínhamos a pretensão de realizar as entrevistas com 20 sujeitos independentes, isto é, com apenas um dos membros da família, o pai ou a mãe. Todavia, encontrar pais voluntários que se dispusessem a falar foi também uma tarefa árdua. Uma das dificuldades foi encontrar pessoas que atendessem aos critérios estabelecidos. Três pessoas indicadas por conhecidos não puderam participar, pois a situação da adoção era bastante peculiar, não correspondendo aos propósitos da pesquisa. Cinco pessoas que contatamos por sugestão de amigos desistiram de participar, alegando indisponibilidade de tempo. Pessoas que trabalhavam diretamente com grupos de adoção assinalaram que eram poucos os pais com filhos adotivos adolescentes que permaneciam em contato com o grupo 
de apoio, pois iam se afastando conforme passava o tempo. Outros pais tinham adotado um adolescente há pouco tempo, e a família ainda estava em fase de adaptação.

Depararmo-nos com essas situações foi frustrante, implicando a redução de entrevistas. Reiteramos que todos os entrevistados foram indicados por pessoas conhecidas. Até uma das mães, que trabalha com a questão da adoção e tinha recebido a carta on-line através de um dos grupos de apoio, só aceitou participar da pesquisa depois de uma conhecida em comum ter conversado com ela.

Logo, no total, foram entrevistados dez sujeitos independentes, oito mães e dois pais adotivos, todos pertencentes às camadas média e alta da população carioca. Os filhos adotivos desses sujeitos se encontravam no período da adolescência, entre os 13 e 18 anos, conforme postula Emmanuelli (2005). Com relação à configuração familiar, apenas duas mães formavam uma família monoparental, quando adotaram seus filhos. Ambas tiveram um filho biológico no casamento e após a separação desejaram adotar um filho. Todos os participantes pertenciam a famílias heterossexuais, e três deles permaneciam casados, dois tinham união estável, três eram separados e um era viúvo

Como critério de delimitação e de aproximação do perfil dos sujeitos, ficou decidido que seriam entrevistados pais que adotaram os filhos até os 12 anos de idade, cuja adoção não fosse um segredo na família. Outro critério foi o fato de a adoção ter sido realizada há pelo menos dois anos, de modo que a família não estivesse atravessando o período de adaptação e já tivesse certo período de convivência familiar.

Os dez sujeitos participantes preencheram os critérios mencionados e concordaram em assinar um termo de consentimento (Anexo IV) para a utilização dos dados em pesquisa e publicação. Devemos dizer que foi necessário omitir, ou alterar, alguns dados, cuja finalidade era preservar a identidade dos participantes. Ressaltamos, porém, o cuidado para que esta necessidade não provocasse qualquer desvio nos resultados obtidos.

Salientamos que, devido ao número restrito de sujeitos participantes, esta pesquisa deve ser considerada exploratória, tendo como finalidade ampliar a compreensão e as questões vividas pelas famílias adotivas. Portanto, o material obtido apresentará apenas algumas das questões relativas às vivências dos pais a respeito da parentalidade e da filiação durante a adolescência. Neste caso, não 
pretendemos formular conclusões generalizadoras. Mas acreditamos na relevância deste estudo, porque consideramos que cada sujeito carrega a sua verdade, e esta nos leva a uma maior compreensão da complexa constituição dos vínculos familiares, e, assim, a questões ainda incipientes na literatura.

No quadro abaixo, encontram-se os dados biográficos ${ }^{1}$ de cada um dos sujeitos.

\begin{tabular}{|c|c|c|c|c|c|}
\hline & Idade & Estado civil & Filho adotivo & $\begin{array}{l}\text { À época da } \\
\text { adoção }\end{array}$ & $\begin{array}{c}\text { Filho biológico/ } \\
\text { Enteado(a) }\end{array}$ \\
\hline Pai 1 & 63 & $\begin{array}{l}\text { Separado } \\
\text { há } 4 \text { anos }\end{array}$ & Filho - 18 anos & Bebê de 1 ano & - \\
\hline Pai 2 & 61 & $\begin{array}{l}\text { Viúvo } \\
\text { há } 3 \text { anos }\end{array}$ & Filha -17 anos & Bebê de 1 mês & $\begin{array}{l}\text { Filha }-30 \text { anos } \\
\text { Filho }-27 \text { anos }\end{array}$ \\
\hline Mãe 1 & 58 & $\begin{array}{c}\text { Casada } \\
\text { há } 37 \text { anos }\end{array}$ & Filho - 17 anos & Bebê de 4 meses & $\begin{array}{l}3 \text { Filhas entre } \\
36 \text { e } 27 \text { anos }\end{array}$ \\
\hline Mãe 2 & 33 & $\begin{array}{l}\text { União estável } \\
\text { há } \\
15 \text { anos }\end{array}$ & Filha -14 anos & $\begin{array}{c}\text { Pré-adolescente } \\
12 \text { anos }\end{array}$ & - \\
\hline Mãe 3 & 51 & $\begin{array}{c}\text { Casada } \\
\text { há } 20 \text { anos }\end{array}$ & Filho - 18 anos & Bebê 1 mês & - \\
\hline Mãe 4 & 50 & $\begin{array}{c}\text { Separada } \\
\text { há } 11 \text { anos }\end{array}$ & Filho - 14 anos & Criança de 7 anos & Filho - 18anos \\
\hline Mãe 5 & 65 & $\begin{array}{c}\text { União estável } \\
\text { há } 23 \text { anos }\end{array}$ & Filho - 17 anos & $\begin{array}{l}\text { Bebê entre } \\
\text { o } 1^{\circ} \text { e } 3^{\circ} \text { mês }\end{array}$ & $\begin{array}{l}\text { Enteada } \\
\text { (34 anos) }\end{array}$ \\
\hline
\end{tabular}

\footnotetext{
${ }^{1}$ Em todos os casos descritos, os nomes foram substituídos, assim como alguns detalhes biográficos e da história familiar. Foi necessário fazer determinadas alterações para que as identidades das famílias fossem preservadas e, assim, se mantivesse o compromisso ético do sigilo, garantido aos entrevistados.
} 


\begin{tabular}{|c|c|c|c|c|c|}
\hline Mãe 6 & 45 & $\begin{array}{l}\text { Casada } \\
\text { há } 20 \text { anos }\end{array}$ & $\begin{array}{l}1^{\text {a }} \text { Filha } \\
15 \text { anos } \\
2^{\text {o }} \text { Filho } \\
19 \text { anos } \\
3^{\circ} \text { Filho } \\
17 \text { anos } \\
4^{\text {o }} \text { Filho } \\
11 \text { anos }\end{array}$ & $\begin{array}{l}1^{\mathrm{a}} \text { Filha }-4 \text { anos } \\
\text { Após } 1 \text { ano } \\
\text { da } 1^{\mathrm{a}} \text { adoção } \\
\text { (3 irmãos } \\
\text { biológicos) } \\
2^{\circ} \text { Filho }-9 \text { anos } \\
3^{\circ} \text { Filho }-7 \text { anos } \\
4^{\circ} \text { Filho }-1 \text { ano }\end{array}$ & $\begin{array}{l}\text { Enteado } \\
\text { (25 anos) }\end{array}$ \\
\hline Mãe 7 & 46 & Separada & Filho -13 anos & 9 meses & Filha -25 anos \\
\hline Mãe 8 & 55 & $\begin{array}{l}\text { Separada } \\
\text { há } 7 \text { anos }\end{array}$ & Filho -15 anos & $\begin{array}{l}\text { Bebê "com dias } \\
\text { de vida" }\end{array}$ & - \\
\hline
\end{tabular}

\section{2.}

\section{Instrumentos e procedimentos}

Antes da entrevista, os sujeitos pesquisados forneceram seus dados biográficos, preenchendo uma ficha (Anexo III) na qual constavam perguntas sobre idade, sexo, estado civil e composição familiar. Para a obtenção de dados específicos foi utilizada, como instrumento, a entrevista semiestruturada, elaborada por meio de um "roteiro invisível", delineado com base na fundamentação teórica. Cabe ressaltar que, com vistas a aprimorar o instrumento, realizamos um estudo-piloto, buscando analisar se o roteiro invisível atingia o objetivo proposto. Esse tipo de roteiro consiste em perguntas abertas, as quais não impedem o aprofundamento de questões que surjam ao longo da entrevista, centradas em temas sobre a relação parento-filial, a história da adoção e sua revelação, e a vivência da passagem do entrevistado pela sua própria adolescência e pela do filho.

Por meio do estudo-piloto, decidimos modificar a pergunta disparadora do "roteiro invisível". Essa alteração se fez necessária ao percebermos que, inicialmente, a mesma estava entrelaçada somente à experiência de ser um pai 
adotivo. Notamos que os pais, ao falarem depois sobre a adolescência, pareciam desconfortáveis, reforçando a normalidade da adolescência dos filhos, talvez para, defensivamente, não relacionar "a crise da adolescência" ao fato da adoção.

Levando isso em consideração, decidimos incluir na pergunta disparadora tanto a parentalidade adotiva como a parentalidade na adolescência: Como é a experiência de ser pai adotivo no período da adolescência? Desse modo, pensamos que a abordagem logo de início das duas principais questões da parentalidade daria maior liberdade aos pais para falar do tema que provavelmente os mobilizava mais. Devemos esclarecer que, apesar de a pergunta disparadora ser diferente nas três entrevistas realizadas no estudo-piloto, essas perguntas foram incluídas neste estudo final, após uma criteriosa avaliação e verificação de que o material não era incompatível com os demais.

As entrevistas foram todas efetuadas pela pesquisadora, com cada sujeito individualmente, em um local determinado por ele. Cabe mencionar que todas as entrevistas foram gravadas e transcritas, conservando o máximo de informações, tanto em seu conteúdo como na forma da comunicação (pausas, perturbações de palavra, aspectos da emoção, tom de voz).

\section{3.}

\section{Análise e discussão dos dados}

A análise dos dados teve como método a análise de conteúdo, procurando compreender no material discursivo os significados manifestos e latentes, com a finalidade de evidenciar as significações que os entrevistados atribuíam aos fenômenos (BARDIN, 1977/2010; WEBER e DESSEN, 2009). A fim de obter uma profundidade interpretativa na exploração do material de comunicação, foram utilizadas duas técnicas pertencentes ao método da análise de conteúdo, concebendo-as como complementares.

A primeira técnica usada foi a clássica categorial, por meio da qual são destacadas categorias temáticas, organizadas a partir da frequência e da semelhança entre os elementos contidos no material coletado. "Cada categoria, então, deve incluir todas as particularidades possíveis de um conjunto de pesquisa" (WEBER e DESSEN, 2009, p. 45). Para tal, procedeu-se a uma "leitura flutuante", conforme determina Bardin (1977/2010), dos conteúdos das 
entrevistas, investigando-se elementos significativos, hipóteses e ideias, a fim de se destacar as categorias. Essa "leitura flutuante" compôs a etapa de pré-análise. Em seguida foi realizada a codificação e o agrupamento de temas, identificandoos e relacionando-os.

Concomitantemente à técnica de categorização, o material também foi submetido à técnica de enunciação. Conforme afirma Bardin (1977/2010), essa técnica complementa uma análise categorial. Ela se diferencia de outras técnicas, pois se apoia na "concepção da comunicação como um processo e não como um dado", considerando a expressão da ambivalência, dos conflitos e do paradoxo presentes no psiquismo do sujeito, que são expressos no discurso (p. 215).

O foco desta técnica é a compreensão do discurso como um processo de elaboração. Caracteriza-se por analisar a dinâmica da entrevista mediante as figuras de retórica, e por elucidar os elementos formais atípicos (omissões, ilogismos, silêncios, lapsos, entre outros). A análise da enunciação diz respeito ao estudo sobre o conteúdo do discurso, abarcando a estruturação e a transformação do conteúdo provocada pelo fluxo das mensagens. Pensamos que os elementos extraídos por meio dessa técnica enriquecem a investigação, permitindo que sejam analisados os conteúdos latentes no discurso manifesto.

Devemos, primeiramente, apontar a complexidade de destacar elementos comuns a todas as histórias relatadas, na medida em que cada uma delas contém uma vasta gama de aspectos singulares, que se distinguiam intensamente e se mostravam imprescindíveis para a compreensão do percurso de vida de cada um dos sujeitos. Esses aspectos singulares estavam presentes, por exemplo, na vivência dos pais de sua própria adolescência, na história pregressa de seus filhos adotivos e nas situações de vida pelas quais ambos viveram juntos, tais como mortes de familiares e doenças graves.

Para extrair as categorias, foi necessário atentar para temas semelhantes e frequentes nos discursos, que foram agrupados em sete categorias de análise: motivações manifestas e latentes, informações sobre a adoção, mito de origem, identificação e identidade, rede de apoio, parentalidade na adolescência e, por fim, o "insondável”. 


\subsubsection{Motivações manifestas e latentes}

Como foi mencionado, é importante refletir sobre as motivações dos pais para adotar um filho, a fim de ter uma compreensão mais apurada sobre o desenvolvimento dos vínculos (LADVOCAT, 2010; TRINDADE-SALAVERT, 2010; FILHO, 2008; LEVINZON, 2000; SCHEJTMAN, 1990). Na literatura, as motivações acabam sendo classificadas por sua finalidade e fonte de origem, como a infertilidade, a perda de um filho, a transmissão familiar e a filantropia (FILHO, 2008; TRINDADE- SALAVERT, 2010; LEVINZON, 2000; LEVY e FÉRES-CARNEIRO, 2001; SCHEJTMAN, 1990). Algumas delas são apontadas como motivações que podem trazer consequências dramáticas para a adoção.

Pensamos que talvez o efeito nocivo dessas motivações ocorra devido a uma dose maior de narcisismo do que de altruísmo. Ou seja, os pais podem entrar em contato somente com suas necessidades, não conseguindo se aproximar do filho e reconhecer as necessidades dele. Os discursos dos entrevistados nos ajudam a constatar a grande variedade de fantasias envolvidas na escolha da adoção.

O primeiro ponto observado, dentro desta categoria, foi que para os entrevistados (seis sujeitos) com algum problema de fertilização, por parte deles ou dos cônjuges, a adoção veio como uma opção secundária de ter um filho. Conforme é apontado na literatura, isso já marca os futuros pais, promovendo feridas narcísicas. A condição de ser pai e mãe já se inicia com a frustrante confrontação com a castração na sua condição de reproduzir. Percebemos, por meio das narrativas, que a maioria dos entrevistados não mencionou de forma explícita a frustração e o sofrimento de não poder ter o filho biológico. Apenas a Mãe 6 fez referência à sua tristeza, o que nos levou a pensar que, possivelmente, seja um luto de difícil elaboração, precisando recorrer a defesas mais rígidas.

(Pai 1)

Quer dizer, a questão da adoção veio em função de uma impossibilidade da (exmulher) ter filhos. Quando nós decidimos ter filhos, a gente não conseguiu, quando foi ver, ela tinha um problema físico, que não permitia ela engravidar. (Motivação manifesta)

(Conta rápido, parecendo não querer falar sobre este ponto.) 
(Pai 2)

No primeiro parto, ela teve ruptura de útero, aí não era recomendado ter o segundo filho. E ela teve o segundo filho, fez tudo escondido de mim e... Aí, ela não ficou muito conformada com isso, aí ela tentou fazer inclusive inseminação artificial. Porque ela era filha única e eu também sou filho único. Ela queria ter três filhos para ter uma família grande. Aí, ela decidiu adotar. Eu para evitar aquele constrangimento de inseminação artificial, eu concordei logo sobre esse negócio de adoção. (Motivação manifesta)

(Mãe 3)

$\mathrm{Eu}$ sempre pensei assim: que filho adotado, ou biológico, não tem diferença nenhuma, tá? De repente entra a religiosidade nisso. (...) Começamos a tentar, e eu não conseguia. Aí, descobrimos que eu tinha as trompas todas obstruídas. Nós fomos procurar um médico para fazer a inseminação. Isso há 20 anos atrás. A probabilidade de vingar era na faixa de $20 \%$. E cada inseminação dessa era numa faixa de 16 mil dólares. Mas, desistimos, depois de fazer todos os exames. (...) Cheguei a tomar algumas medicações. Mas, depois resolvemos apelar para adoção. (Motivação manifesta)

(Mãe 6)

Eu tentei engravidar, fiz inseminação e não consegui. Tentei engravidar e não consegui. E um belo dia, quando uma das fertilizações que eu fiz, que não deu certo, eu fiquei muiiito triste! E eu dizia: "Também, adotar eu não adoto", eu falava. E eu viajei com meu marido, até para dar uma relaxada, porque eu tava bem triste. Depois que eu voltei, eu fui operada. Aí, eu estava em casa e entrou a minha primeira filha, porta adentro. "Oi! Você é minha mãe?" Eu fiz assim: "Ahãmmm? De onde surgiu essa criaturinha?" (Motivação manifesta)

(A menina era filha biológica de um conhecido que não poderia criá-la.)

A partir do discurso da Mãe 3, podemos observar que a afirmação que ela faz, sobre não haver diferenças entre a parentalidade biológica e a parentalidade adotiva, é constituída de representações contraditórias e conflitantes. A nosso ver, se realmente essa mãe considerasse iguais as duas formas de parentalidade, ela teria pensado na inseminação e na adoção simultaneamente. Percebemos claramente que, para alguns dos entrevistados, existe uma hierarquia nas alternativas de parentalidade, a qual é definida pelos significados inconscientes direcionados a cada uma dessas alternativas.

A Mãe 6, por exemplo, explicita que de início não queria pensar em adoção. Esta mãe, sob o ponto de vista psicanalítico, mostra-se mais honesta consigo mesma, com sua realidade emocional. Talvez isso tenha contribuído para ela ser capaz de superar a sua "aversão" à alternativa da adoção. Acreditamos que quanto 
mais o sujeito puder entrar em contato com suas experiências emocionais, mais ele não precisará recorrer a defesas rígidas, como a recusa da sua realidade psíquica, e mais terá condições psíquicas de entrar em contato com a realidade emocional do outro, no caso, de seu filho.

A partir da análise das entrevistas, percebemos que, no cenário da adoção, existem razões motivacionais em dois níveis. No nível consciente, elas são manifestadas com muita naturalidade, sendo apontadas como a única razão para se querer adotar. No entanto, ao longo do discurso observamos que outras motivações são mencionadas, mas não indicadas diretamente como tais. Elas aparecem nos relatos como meros detalhes. Essas motivações são possivelmente inconscientes, ou não estão tão próximas da consciência, já que os entrevistados não as relacionaram com as razões da adoção.

(Mãe 1)

$\mathrm{Na}$ verdade, a experiência é a seguinte: nós não tínhamos mais a intenção de adotar filhos. A gente sempre pensou em um dia, em algum momento, adotar uma criança. Mas depois de três meninas, já duas adultas... não tinha mais ideia de adotar filhos. Só que nós entramos num programa que se chama "família de apoio. (Motivação manifesta)

(A partir do acolhimento temporário ao bebê, houve uma vinculação.)

(Mãe 1)

Quando a gente comentava assim: "não foi possível aquele projeto, né, de adotar uma criança", o meu marido dizia: "nós vamos adotar uma menina, isso se nós fôssemos escolher". Porque ele não queria que tivesse aquela sensação de que: "olha, nós só adotamos porque era um menino". E no final veio um menino, sem que a gente procurasse. Sem que a gente fizesse nada pra isso. (Motivação latente)

(Posteriormente, comentou que na família do marido existiam sete crianças adotivas.)

(Mãe 2)

Bem, eu posso ter filhos, mas qualquer gravidez que eu tenha é uma gravidez de risco. Porque eu sou vítima de três tromboses. Eu, antes, já não me via gestante, ao contrário da maioria das mulheres, que tem aquele sonho assim: "Ah, eu vou engravidar, eu vou ver minha barriguinha crescendo". Eu não tinha esse tipo de sonho. Eu não conseguia, não me via em uma situação (gravidez)... parar minha vida, né. (...) Só que nós chegamos num momento da nossa vida em que eu falei para ele assim: "Eu tenho vontade de ser mãe". Eu nunca me imaginei carregando um bebê no colo, gestante, essa coisa toda. Mas eu sempre tive vontade de ter mais alguém na família, de desenvolver mais assiduamente esta questão da maternidade. (Motivação manifesta) 
(Mãe 2)

Eu fui criada basicamente pela minha mãe. O meu padrasto faleceu, eu era adolescente. Sofreu um acidente e faleceu. Minha mãe que me criou (se enrola para falar). E ela casou a segunda vez, quando eu tinha cinco anos de idade. Aos 13 anos, meu padrasto faleceu. Então, quem basicamente, durante todo o período de vida, foi minha mãe e meu pai foi a minha mãe! Ela fez os dois papéis! E, assim... eu sempre aprendi o seguinte: "Eu tenho que ser independente, eu tenho que correr atrás da minha vida". Entendeu? (Motivação latente)

(Mãe 4)

(Responde à pergunta das motivações para a adoção relembrando o fato de ter feito um aborto aos 17 anos.)

Então, quer dizer essa coisa de adoção, sempre teve muito presente na minha vida. E não digo culpa, em relação àquele outro fato que te falei, porque foi algo que (gagueja)... uma atitude que eu tomei na minha adolescência, mas muito consciente. Eu não tinha condições, eu não tinha idade, eu não era autossuficiente. Eu dependia dos meus pais, eu não tinha como ter um filho. Então, foi uma coisa ( $o$ aborto) muito tranquila. Claro! Você sofre, porque não é uma situação que ninguém queira viver. Mas é uma situação muito tranquila. O quanto talvez meus pais eram contra esse tipo de comportamento, o quanto eles poderiam ter acolhido, entendeu? $\mathrm{E}$ até depois uma coisa religiosa mesmo. Mas, na época, não foi uma coisa que me desse nem culpa, nem... E talvez isso, depois fosse mais um adicional, entendeu?! Mas, adicional no sentido assim: Vamos resgatar, de alguma maneira, determinados pecados, ou coisas que você fez e que não precisava ter feito. Então, motivos tiveram muitos! E, basicamente, eu não queria ter filho único. Eu vejo apesar dos conflitos, de brigas de irmão. Aquela confusão! Apesar disso, eu acho muito bom. Eu sinto que a casa fica mais viva, tem mais vida, porque tem mais criança. E eu acho que é fundamental você ter essa possibilidade de ter um irmão. De saber dividir, de saber compartilhar. (Motivação latente e manifesta)

(Mãe 8)

Eu engravidei quando eu tinha 36 anos e perdi o neném. A adoção sempre esteve assim, desde os 15 anos, no ar, né?! E quando eu me casei com meu ex-marido, ele falou: "Olha, se a gente não tiver, a gente adota". Isso já foi o máximo! Engraçado, não sei por que ele falou isso, já que nada dizia que a gente não teria filhos. E eu fiz alguns tratamentos, mas os tratamentos que eu fiz me engordaram muito, eu tive uma reação hormonal e chegamos à conclusão de que não valia a pena. Porque eu tava com 38 anos, eu falei: "Não vale a pena eu ficar tentando, vamos partir para a adoção". E foi aí que a gente partiu para a adoção. (Motivação manifesta)

(Mãe 8)

Meu pai começou a ficar doente quando eu tinha 18 anos. Ele morreu quando eu tinha 21. Então, isso aí abalou muito a estrutura familiar, nós éramos cinco. Então, isso abalou um pouco, e uma coisa que me chama atenção agora. Quando eu tinha 15 anos, eu sempre pedi à minha mãe, apesar dos cinco filhos, eu sempre 
pedi que ela adotasse uma criança. É porque eu queria um bebezinho para cuidar e que não sei o que... Aí minha mãe falou: "Oh, você que vai adotar, eu não vou não. Cinco já tá suficiente!". Eu sempre brincava assim, e que eu me lembre é isso. Eu era uma pessoa muito determinada. (Motivação latente)

Pelos relatos acima, podemos constatar que são amplas as motivações inconscientes envolvidas em uma adoção, tais como: a transmissão psíquica familiar do marido e o desejo da Mãe 1 de ter um filho homem; o desamparo vivido pela Mãe 2, que sofreu com a ausência do pai e possivelmente teve que ser mãe dela mesma para não sobrecarregar sua mãe; o sofrimento da Mãe 4 pelo aborto e sua tentativa de reparação; e por fim, o desejo adolescente da Mãe 8 . Todas essas prováveis motivações latentes são promovidas por diferentes fantasias.

Schettini, Amazonas e Dias (2006) e Lopes (2008) destacam a importância de se trabalhar o desejo dos candidatos à adoção. No entanto, devemos ter em mente o limite desse trabalho, pois existem representações inconscientes associadas ao desejo de adotar e ao significado de ser pai/mãe e de ter um filho, às quais talvez nunca tenhamos acesso. Pretendemos com isso ressaltar que o trabalho especializado, que antecede a adoção, não deve ser encarado como infalível na prevenção de problemas futuros.

Por exemplo, é possível ouvir algumas afirmações de grupos sociais que se opõem aos pais que fazem muitas restrições ao perfil do filho que almejam adotar. A Mãe 7, que trabalha em projetos de adoção, aborda esta questão:

A gente está conseguindo milhões de adoções tardias sendo feitas com sucesso, temos adoções inter-raciais. Mas, o que eu debato muito, é que isso não é receita de bolo. A gente, óbvio, que tem que trabalhar os conceitos, tem que trabalhar as coisas, mas você não pode, e isso eu debato muito, você não pode fazer uma pessoa adotar uma criança negra se ela não tem preparo para aquilo. Eu defendo a escolha do perfil! Você não pode imputar uma pessoa a adotar uma criança mais velha... eu não tenho condições de adotar uma criança mais velha, eu não teria condições de fazer uma adoção tardia.

Após uma avaliação das entrevistas, defendemos o mesmo ponto de vista da Mãe 7, com base nos dados adquiridos nos relatos. Percebemos que até mesmo as preferências de cada pai, como o sexo da criança ou a idade, encontram motivações em sua própria história. Por isso, destacamos que a escolha do perfil é muito mais do que cognitiva ou preconceituosa, ela tem origem nas vivências emocionais ao longo da vida dos candidatos a pais. 
No caso da Mãe 2, por exemplo, ela comentou que sua mãe assumiu as funções de mãe e de pai, devido às mortes precoces do primeiro e do segundo marido. Talvez por alguma razão muito primitiva, ela não se via grávida, não queria ter um bebê, havendo desejo de ter um filho, porém não de engravidar. Para essa mulher, a gestação não é condição de maternidade, e esta independe daquela, sendo a gestação inviável psiquicamente de ser vivida. Talvez ela não tivesse disponibilidade interna para esta relação primitiva de dependência absoluta.

O caso da Mãe 5 também nos ajuda a defender nosso ponto de vista. Para ela, ser mãe requer um bebê. Por isso refutou a sugestão dos profissionais de realizar uma adoção tardia, sugestão motivada pelos seus 45 anos de idade à época. Ela também exigiu que seu bebê fosse um menino, pois tinha a crença de que homem sofreria menos. Em sua história de vida, declara que a mãe tinha preferência por filhos homens e que não se sentia amada por ela, talvez nem mesmo reconhecida (afeto representado no ato falho que comete). Além disso, revelou que o pai era agressivo com sua mãe, talvez constituindo a representação da condição de mulher como um ser vulnerável, sofredor e pouco amorável.

Mas, a psicóloga vinha na minha casa e a assistente social vinha também. Aí, ela dizia para mim: "Você tem certeza que você vai querer um bebê?" Eu falei: "Eu quero um bebê porque eu quero ser mãe. Quero sentir as coisas convincentes, embora não vá engravidar". Ela dizia: "Será que não era melhor uma criança maior, de 2 anos?" Eu falei: "Eu não quero criança maior. Eu quero pequenininho". Aí aquilo foi passando e eu fiquei dois anos na fila, entendeu? (...) Ahhh, e outra coisa que eu queria também! Eu queria que fosse homem, eu não sei por quê. Porque o homem sofre menos, não sei.

Meu pai brigava muito com a minha mãe também. Eu gostava muito do meu pai, mas eu detestava aquela atitude dele, entendeu, com a minha mãe. Agora, eu gostava muito da minha mãe também. Mas a minha mãe teve dois (ato falho), três filhos. A minha mãe não era muito apaixonada por mim. Ela gostava mais dos filhos homens, que ela tinha dois.

Conforme Winnicott (2005) afirma, por mais que uma família faça tudo de melhor por seus filhos, isso não será garantia de que eles alcancem a plena maturidade. $\mathrm{O}$ desenvolvimento e o sucesso das relações dependem de muitos fatores, como a interação familiar e a economia interna de cada indivíduo. Devemos considerar que tanto a escolha de ter um filho pela adoção como a seleção dos critérios envolvidos na mesma se devem a razões profundas da história de vida e de condições internas desses pais adotivos. Aos profissionais, 
cabe compreender, orientar e respeitar toda a trama de representações e fantasias presentes na motivação de ser pai ou mãe adotivos.

\subsubsection{Informações sobre a adoção}

Vimos, ao descrever as formulações teóricas, o quanto é sugerido aos pais adotivos que contem a história da adoção a seus filhos o mais precocemente possível. Caso as crianças sejam mais velhas, os profissionais da área também sugerem aos pais que estejam preparados para falar com os filhos sobre o assunto, quando for necessário. Contar a história para o recém-chegado representa envolvê-lo em um discurso que o inscreve na cadeia genealógica, ou seja, naquela história familiar, compondo a sua subjetividade.

Lembremo-nos da colocação de Golse (1999) sobre o "ato de palavra" ser um processo de significação e de ligação. Ainda que o bebê não compreenda as palavras, ele é capaz de identificar a particular atmosfera emocional. Dessa maneira, apesar de ele não entender exatamente o sentido das palavras, é preciso reconhecer e valorizar sua compreensão a partir da apreensão emocional.

Sendo assim, propomos pensar a informação sobre a história de origem para o filho adotivo como um dos aspectos da formação do vínculo afetivo parentofilial. A informação precoce é o importante prelúdio do vínculo e da conexão emocional com o filho. Isso faz lembrar o paradigma do "tá ligado?", descrito por Forbes (2011). Consideramos que o ato de narrar a história de origem possibilita que os pais adotivos se capacitem a "estar ligados" ao filho e a si mesmos, em múltiplos aspectos.

Todos os seis entrevistados que adotaram seus filhos ainda bebês falaram precocemente sobre a adoção. Todos usaram o artifício de contar uma história, algumas criadas por eles mesmos, outros preferindo recorrer a livros infantis que abordavam o tema. Pensamos que já na escolha de como informar sobre a origem, omitindo ou valorizando certos fatos, os pais revelam a sua singularidade.

Diante da recomendação generalizada sobre a importância de informar a criança sobre a adoção, percebemos que o que faz diferença é a forma como essa comunicação será feita. Este "ato palavra" recebe o colorido da subjetividade dos pais adotivos. Damos destaque a tal questão para ilustrar o quanto o psiquismo singular de cada pai atravessará a maneira do quando, do como e do que será 
informado sobre a origem, abarcando muito mais do que a simples e genérica recomendação de ser revelada a história.

(Pai 1)

(...) Diana começou falando para ele que ele era filho do coração. Não tinha vindo da barriga, enfim, que era do coração. Então, começou a introduzir esta questão... para ele ter consciência sobre esta questão. Tanto é que um dia, quando ele tinha mais ou menos uns quatro anos, por aí, ele pediu pra Diana um irmãozinho, porque ele se sentia muito solitário, sozinho. Mas aí a Diana falou: "Mas, você sabe que a mamãe não pode ter filho, né? Filho da barriga. Só pode ter filho do coração". "Então, vai lá naquele local e arranja outro, pô" (disse o filho). Você viu que ele estava resolvido, né?

(Pai 2)

E a gente trouxe nosso bebezinho, sempre dizendo que ela é filha do coração... A gente sempre falou que tem o filho do coração e o filho da barriga. A gente sempre falou sobre isso com ela, tudo direitinho. E ela sempre aceitou, brincava sobre isso e tal. Ela gostava de ser diferente dos outros dois (irmãos) quando pequena, pensava: eu sou desejada, eu sou do coração.

(Mãe 1)

Desde que ele era bebezinho, eu dizia para ele. Isso era uma orientação de uma médica homeopata: 'Você sempre diga para ele desde que ele é bebê. Agora, assim, ele não sabe o que você tá falando, mas o dia que ele souber o assunto, não vai ser novidade pra ele. Ele ouviu essa história'. Então, desde bebezinho eu dizia para ele assim: 'Ah, quando você chegou, você tinha quatro meses, você era um bebezinho lindo'.

(Mãe 3)

Eu sempre falei com meu marido que eu tinha muito medo de ter que um dia chegar para ele (o filho) e falar: "Você não é meu filho". Eu tinha um medoooo!... de não saber falar! Então, o que eu fiz desde o primeiro dia, eu conversava com ele. Eu dizia que ele não tinha saído de dentro de mim, mas que ele estava no meu coração. E que ele era muito amado. Vivia com ele no meu peito. Um frio louco que tinha feito aquele ano na minha casa! Mas eu pegava ele, sem nada no peito, com um roupão por cima, para ele ter o contato de mãe, de pele. Isso eu fiz muiiito com ele, e o meu marido também. Querendo dar tudo que ele não teve para compensar. (...) E na época eu procurei saber, e descobri que muitas das crianças que tinham abandono, após o parto, morriam. Era um número pequeno de sobrevivência. Então, eu tinha um contato muito grande em relação a isso.

Nas falas destacadas acima, podemos observar que as narrativas descrevem o início da vinculação. Portanto, a origem da filiação e da parentalidade adotivas. Percebemos, nas narrativas, que predominam as expressões não é "filho $d a$ barriga" e sim "filho do coração". Compreendemos que, dessa maneira, os pais estão explicando, em uma linguagem possível, coloquial, não acadêmica, que os 
elos de parentalidade têm como base o eixo da filiação afetivo-imaginária (o coração - lugar imaginário das emoções), e o buraco/a falta do eixo da filiação biológica (barriga). Tanto a barriga quanto o coração são partes do corpo humano, assim como a filiação biológica e a filiação afetivo-imaginária são partes do "corpo"/estruturação do processo de filiação. Contudo, na adoção, uma das partes (o coração) liga e legitima o vínculo, enquanto a outra (a barriga) aponta para a falta, a descontinuidade. Ambas formam uma dupla indissolúvel, uma vez que não se fala de uma sem falar da outra, ficando evidente a instalação de uma dialética indelével da adoção.

Ser do coração talvez traga aos envolvidos, mesmo que num nível inconsciente, a valorização e uma exigência na qualidade da relação, pois afinal o que os une são os afetos. Ponderamos que isso pode ser benigno, na medida em que estejam atentos aos afetos, mas pode ser empobrecedor, se houver uma imposição superegoica e uma intolerância às vicissitudes afetivas de qualquer relação objetal. Ou seja, não ser suportável, na relação parento-filial, que haja continência e elaboração no tocante aos afetos hostis.

O Pai 1, ao contar o pedido do filho de ter um irmão, apresenta a dubiedade de sua ex-mulher a respeito da filiação: “(...) você sabe que a mamãe não pode ter filho (...)”. O menino aponta que ela pode ter do mesmo jeito que ela o teve. Todavia, para ela isso não é tão claro, pois talvez o luto pela não vivência da parentalidade a partir da experiência biológica não tenha sido suficientemente elaborado. Dessa maneira, a mãe adotiva não pode pensar sob a lógica aparentemente óbvia do filho, o que retorna primariamente é a sua impotência de ter o filho biológico.

No discurso da Mãe 3, também ficam explicitadas a sua ambivalência parental e a dubiedade concernente à filiação. Ela diz ter sido inicialmente difícil contar a história da adoção, porque como falaria: "Você não é meu filho". Ela alega ter tido medo de não saber falar. Propomos pensar que possivelmente ela teve medo de falar para si mesma. A Mãe 5 parece demonstrar uma dificuldade de legitimar o lugar do filho adotivo como realmente "seu" filho.

De modo geral, podemos afirmar o quanto nos discursos as defesas se revelam ao expor as contradições, e onde existem defesas existem conteúdos a serem defendidos. Entendemos que essas duas falas exemplificam a precariedade na elaboração do luto pelo "filho da barriga" e quanto esta realidade psíquica 
precisa ser aplacada. O resultado emocional é construir uma filiação ambígua, inviabilizando a mãe ou o pai de legitimarem a parentalidade adotiva, ou seja, a vivência integrada de serem pais. É como se na mente da mãe ou do pai as representações e os afetos ligados ao filho que não pôde existir suplantassem, na mente dos mesmos, o filho que pode existir.

Pontuamos, em suma, que o contar a história é muito mais do que dizer a verdade ou informar os fatos. Esta atitude diz respeito ao início do elo de parentesco, da metabolização do estar ligado pelo coração e não pela barriga (o elo em sua concretude via cordão umbilical). Relembremos as considerações de Eiguer (2012), referentes aos costumes de grupos empresariais de contar a história da empresa a seus novos funcionários, a fim de suscitar nestes o senso de pertencimento. Desse modo, o ato de contar é fazer-se pertencer, afiliar-se. Logo, emociona e mobiliza as muitas fantasias presentes na vinculação.

(Mãe 8)

A história, eu contei desde que ele chegou. Tem um livrinho de uma psicóloga, foi o único livro que eu consegui, antes de eu ir adotar. E era a história da Maria estrelinha, uma coisa assim. A história de uma estrelinha que foi adotada por um cometa. E aí, eu contava para ele desde que ele chegou, até mesmo para ele ouvir a minha voz. E isso eu falo sempre, porque eu só consegui ler o livrinho de dez páginas depois de uns dois meses, porque eu chorava. Era tanta emoção, que eu mesmo chorava de emoção. Era até uma maneira de me acostumar a contar a história para ele. Aí eu... ele sabia dessa história.

(Assim, ela e ele entrelaçavam suas histórias.)

Dentro desta categoria existe um aspecto importante a ser abordado, que diz respeito aos elementos que os pais omitem em relação à história pregressa do filho adotivo. Constatamos que, apesar de os pais ressaltarem a necessidade de falar a verdade, três deles explicitaram a omissão de alguns detalhes sobre a origem biológica dos filhos, alegando ser desnecessário que os filhos tomem conhecimento disso. Este dado corrobora a afirmação já mencionada de Souza e Casanova (2011) sobre a revelação da história da adoção, considerando-a como um ato que significa muito mais do que a revelação de fatos. Se fossem apenas fatos não haveria dificuldades, o grande conflito é porque é um ato de transmissão de sentidos, de significado de experiências emocionais, muitas vezes, insuportáveis para os próprios pais. 
(Pai 1)

Eu sempre falei de uma maneira difusa. Eu também nunca fiquei contando historinhas pra ele. Sempre contei uma coisa difusa, pra se perder. Se você conta muito, você estrutura uma imagem. Digamos, essa imagem eu procurei deixar o mais romântica possível e o mais enevoada possível, para ela se dissipar tranquilamente. A imaginação dele poderia construir 'como seria a minha mãe?' A mãe dele é a Diana. Nunca teve esse personagem a mãe. Teve aquele lugar onde nos encontramos, a origem... tá aí. Reconhecer. Ficou uma coisa assim. E não que nasceu de uma mãe, uma história triste e pipipi... Não. Como se fosse uma coisa, fosse assim uma coisa Indiana Jones. A gente se encontrou e tal, ele passou por peripécias. (A história do filho, de fato) Foi um caso policial. Mas essa historinha não existe. O que existe é aquela coisa como se tivesse vindo e passou por uma série de peripécias. E a gente se encontrou um dia lá.

(Mãe 1)

Não contava as mazelas do hospital. Não falava nada da outra mãe... só falava isso: "Ah, você era um bebezinho e você chegou e não sei o quê e tal". Ele também não tem esse histórico de que veio ficar uns dias e ir embora. Isso ele não sabe. Até hoje! Porque, também, não vi necessidade de falar. Em algum momento ele vai saber, porque eu tenho tudo guardado, o histórico do hospital, a tutela. Então, ele vai entender que teve aí um...um... algum momento que ele ainda não conhece. Mas eu dizia sempre pra ele. Sempre contava a história dele. Hoje em dia, ele não me pede mais.

(Mãe 3)

(Esta mãe disse que seu filho fora deixado com um juiz, mas no decorrer da entrevista ela contou outra versão dos fatos.)

A verdade, a verdade de como foi achado: isso ele (o filho adotivo) não sabe! Agora, a gente falou para ele que a gente tem o processo, a gente tem em casa. A gente falava que quando ele tivesse 15, 16 anos: "Se você quiser saber, nós vamos ao juizado e pegamos o processo todo". Mas ele nunca tocou nisso. (...) Mas a gente não entra em detalhes. Ele foi abandonado no quintal de uma casa com cachorros_que latiam muito. Isso pouca gente sabe! Por exemplo, ele tem pavor hoje, que ele está com 18 anos, ele tem um pavor inexplicável de cachorro. (...) Isso a gente não fala! Isso, um dia, se ele quiser ver, ele vai ver, porque está tudo no processo. Mas ele não vai querer!

(Mãe 5)

Aí, a psicóloga me ajudou a falar: "Não tem que falar que ele era pobre, e porque a mãe não quis, e aí veio outra”.

Eu achava que sempre se deveria dizer a verdade, sendo que o meu irmão mentiu para a filha adotiva dele. Aí, a vida toda é uma mentira. Aí, eu sou muito esquecida. Então, eu achava que eu não poderia mentir, porque senão, se eu mentisse, eu teria que decorar a mentira. Mas, aí eu não sabia de que maneira falar. Quando ele era pequeninho, eu conversava com ele. Você conversa com o filho situações assim, eu ia falando alguma coisa. Depois, quando ele tinha uns 2 aninhos, 3 aninhos, que ele já falava, ele só dormia com uma história e ele sempre me pedia: "Mamãe, conta uma história". Aí, eu contava uma historinha e ele 
dormia. Eu contava os três porquinhos, todas essas infantis. Foi por aí, eu pegava e contava: "Agora vou contar uma história para você: Era uma vez uma criancinha que estava na maternidade... em um bercinho, e a mãe não ficou com ele porque não quis". Se ele estava compreendendo, não interessava!

(...) Foi assim que contei. Aí, eu contava noutro dia, contava uma vez, contava outra. Um dia, quando eu comecei a contar: "Era uma vez uma criancinha que estava lá na maternidade e não sei o quê...". Aí, ele falou: "Mamãe, você vai contar a minha história outra vez?" Aí, eu tomei um susto com aquilo, entendeu? Aí, eu falei: "É por aí, pronto, já falei!" Falei a verdade.

A Mãe 5 nos conta que a adoção é uma prática familiar em sua história geracional. Contudo, parece que, tanto para ela quanto para o irmão, não existe um registro das experiências primitivas feitas pelo bebê. $O$ filho da Mãe 5 percebe que ela contava a história dele, mesmo sem falar diretamente disso. Pensamos que isso seja possível, não só pelo "ato palavra" como também pelo registro não verbal e precoce que o bebê faz de suas próprias experiências. Pelo relato da Mãe 3 , temos indícios de que esses registros existem e se atualizam no presente. Assim, podemos constatar a pertinência da formulação de Souza e Casanova (2011) ao salientarem que a criança conhece a "verdade", mesmo que num registro de experiência emocional, posto que os fatos e as ocorrências pelos quais ela passou acabam deixando marcas mnêmicas, ainda que fora do registro da palavra.

Parece que alguns entrevistados procuram manter o engano ao desconsiderarem os registros precoces e darem um caráter "inexplicável" quando estes se evidenciam. Pensamos que talvez a preservação desse engano, dessa negação, tenha a função defensiva de aplacar as ambivalências e as dubiedades que compõem a parentalidade, já descritas antes. Para certos entrevistados, talvez, considerar a existência dos registros anteriores à relação adotiva é lembrar-se do luto pelo filho biológico e do sofrimento vivido pelo filho devido à privação do elo com os genitores.

Nos quatro relatos, verificamos que os pais omitiram elementos da história pregressa do filho. Inferimos que o "não dito" talvez tenha sido ocultado devido à sua representação de violência para os filhos. O ser pobre, para a Mãe 5, foi vivido como algo muito prejudicial. Ela ressaltou que pôde oferecer ao filho uma vida muito melhor do que a que vivera, repudiando a pobreza de sua infância, que não lhe dera condições para uma melhor formação. Pensamos que, nestas 
situações que surgiram, talvez, seja difícil falar desses elementos, pois remeteriam os pais a entrarem em contato com sentimentos semelhantes aos dos filhos, vividos em sua própria história familiar. Contudo, o risco é de se criar a proibição inconsciente de um tema, conforme o entendimento de Rotenberg (2011). Lembremos que a autora ressalta como uma das possíveis consequências o surgimento da inibição à tendência natural de buscar o saber.

O "caso policial", as "mazelas do hospital" e o "ataque dos cachorros" foram situações que colocaram a vida dessas crianças em risco real. Elas viveram a ameaça à vida precocemente, em razão da negligência, da desnutrição e do desamparo. Parece que, para esses pais, falar esta verdade é ferir os filhos e a eles mesmos. É mostrar uma realidade que atinge profundamente a condição humana de precisar de seus objetos para sobreviver e ter de confiar neles para poder se desenvolver. Nestas situações houve uma ferida, os objetos primários (os genitores), com os quais o ser humano precisa contar, falharam em sua função.

Discutimos no capítulo dois, as considerações de Freud (1921), principalmente, sobre o quanto o investimento libidinal dos pais em relação ao bebê tem como núcleo a reprodução de seu próprio narcisismo, transformado em amor objetal, constituindo uma tentativa de alcançar o ideal do eu, já que o filho é uma parte deste último. Sendo assim, pensamos que reconhecer as "mazelas" do filho é conviver com uma ferida em seu próprio narcisismo, além de ser um obstáculo no alcance do ideal do eu (ter um filho sem mazelas). Os entrevistados alegaram que omitiram parte da história pregressa para preservar seus filhos, e afirmam que as intenções são benignas, mas acreditamos que também há nisso uma recusa à realidade histórica do filho e uma recusa a reconhecer seu próprio sofrimento diante dessa realidade. Como vimos no caso dos cachorros, as marcas persistem. Se estas não forem reconhecidas e significadas, ficará reduzida a capacidade mental dos pais de serem continentes às "mazelas" de seus filhos.

\subsubsection{Mito de origem}

Refletimos sobre a narrativa e as informações a respeito da condição da adoção, evidenciando o seu caráter dialético, que tanto serve para auxiliar os filhos e os próprios pais adotivos na elaboração de seu lugar na família, como oferece o senso de pertencimento e a lembrança da descontinuidade biológica. Às 
vicissitudes da origem do filho adotivo se junta o fato incontestável de que este vivencia uma dupla fidelidade: à mãe que o criou e à mãe que lhe deu a vida. Portanto, para o adotivo, a questão do senso de pertencimento é complexa por ter este que lidar com um duplo pertencimento em sua subjetividade. Devemos considerar, também, a maneira particular como cada filho irá lidar e encontrar saídas sublimatórias para esse paradoxo do duplo pertencimento.

Foi levantado que muitos dos processos psíquicos se desenvolvem tendo como elemento constituinte o mito de origem. Se isso for levado em conta, os processos se tornarão mais trabalhosos para os envolvidos em uma adoção. Devemos destacar que ser trabalhoso não significa ser ruim ou menos saudável emocionalmente, significa apenas a exigência de uma integrada capacidade mental para a metabolização da castração, das feridas narcísicas e das fantasias.

A partir da análise das entrevistas, percebemos com muita clareza o quanto o mito de origem está pungente na vida dessas famílias adotivas. Pensamos que isso ocorre devido à inquestionável intercorrência na formação da parentalidade e da filiação, em que coexistem duas mães em sua origem, a biológica e a afetivoimaginária.

Estes dados vão ao encontro da afirmação de Abrão (2011) quanto à questão do senso de pertencimento ser mais complexa para o adotivo, porque ele lida com um duplo pertencimento. Discutimos que para um filho biológico questionar as origens é muito menos ameaçador por conta disso, e que no filho adotivo os processos psíquicos que remetem à origem se tornam trabalhosos para os envolvidos. Há um adicional nesta dupla existência: a perda/o luto da primeira origem para existir a segunda. Devemos sempre realçar que a imposição desta realidade não a qualifica nem como algo trágico, nem como algo romântico. Metaforicamente falando, o estilo literário de como a vida será vivida não dependerá dos fatos em si, mas sim do mundo interno de cada sujeito e de como eles interagem entre si.

Nos trechos que iremos destacar, podemos observar com muita clareza a ambivalência dos pais em relação a essa questão. Ao mesmo tempo em que revelam lidar com muita tranquilidade com os lutos presentes na formação do vínculo adotivo, demonstram que não é tão "pura” a manifesta tranquilidade. 
(Mãe 8)

(...) Eu me emocionava. Olha, na época eu não conseguia identificar. Mas, quando o meu filho chegou, a sensação que eu tinha era de um agradecimento, de uma gratidão pela mãe biológica imensa. A minha vontade era de entrar em contato com a mãe e agradecer a postura dela. Depois essa vontade passa! Eu nunca achei que ela pudesse ser uma pessoa desumana. Pelo contrário, eu a achei uma pessoa humana, eu tinha essa vontade. E um dia ainda vou encontrá-la, eu sei que ele ainda vai querer, porque curioso como ele é. Ele vai buscar. E aí já vou estar preparada para isso.

(Mãe 6)

Então, (a irmã) tava grávida, com uma barriga imensa, e o (filho adotivo mais novo), às vezes, colocava a mão na minha barriga e falava assim: "Eu também nasci da sua barriga". Eu dizia assim: "Não, a minha barriga tinha um defeito, e nós precisamos que você nascesse em uma barriga emprestada. Então você nasceu em uma barriga emprestada que se chamava X". E assim, sempre foi. Eu sempre falei para os meus filhos: "A minha barriga tinha um defeito, e nós precisamos de uma barriga emprestada". E Deus me colocou todos prontos, para me avisar que já estavam lá, porque ele (Deus) sabia que, de um em um, eu não teria! Então, realmente nunca foi difícil, porque sempre foi muito normal. E eu me lembro que um dia ele fez um desenho... ele fez um desenho que era uma bola meio aberta, meio ovalada, e uma outra. Uma dentro da outra. E eu falei assim: "O que é isso?" E ele falou: "É uma barriga e um bebê". E eu falei: "Quem é o bebê?" "Sou eu" (responde o filho). E eu falei (tom de animação): "Ah! E a barriga sou eu?" "Claro que não, né, mãe! A sua barriga tinha defeito! Essa barriga é a X”. Eu falei: “Ah, legal”.

A Mãe 8 apresenta uma atitude ambivalente entre querer e não querer conhecer a mãe biológica de seu filho. A Mãe 6, mesmo contando a verdade para o filho, quando este lhe mostra seu desenho sobre a origem, ela nega a realidade, talvez sendo levada a pensar sob a égide do desejo de ter sido também a "mãe da barriga". Os relatos destas situações confirmam a importância, destacada por Abrão (2011), de se elaborar a história de origem, já que ela permeará muitos processos da constituição psíquica e da identidade do filho adotivo.

Ao longo do discurso dos pais, analisamos que a questão da origem está presente em diferentes momentos do ciclo de vida, e relacionada a questões variadas. Encontramos o mito de origem associado, por exemplo: (A) à natural curiosidade infantil sobre a origem dos bebês; (B) à introdução da vida sexual na adolescência; (C) às explicações dos comportamentos; (D) às escolhas das amizades e daqueles a quem os filhos se apegam. É possível observarmos, em 
todos os próximos trechos selecionados, uma maneira particular como cada um dos filhos adotivos elabora a sua história, o seu mito de origem.

\section{(A) (Mãe 1)}

Mas eu dizia sempre pra ele. Sempre contava a história dele. Hoje em dia ele não me pede mais. De vez em quando, ele pedia para contar: "Conta a história de quando eu cheguei, não sei o quê”. E eu contava a história para ele. Aí na escola começaram a falar de raça. Quando ele tinha 5 anos... Antes dos 5, ele de vez em quando perguntava. Mas nada... ele não entendia que ele era adotado. Com 5 anos, ele ouviu que ele era adotado, mas ele também não... vamos dizer assim, entendeu. Com 5 anos ele me perguntou se ele era adotado. $\mathrm{Na}$ escola tavam estudando as raças, aí tinha o japonês, o amarelo, o pardo, o negro, o branco. Aí saiu a história. Aí, eu falei pra ele: "Você não saiu da barriga da mamãe...", mas passou. Ele não falou mais. Com 7 anos foi que realmente ele veio falar no assunto. Veio falar no assunto, aí queria entender. Aí, ele chorou muito. E a minha filha mais nova foi falar com ele: "Mas que bobagem você tá chorando! Você é muito amado, você é filho do papai e da mamãe. É a mesma coisa. Não tem problema de ser adotado". Aí ele respondeu: "É, mas você nasceu da barriga da mamãe. Eu queria sair da barriga da mamãe". Aí, o meu marido teve uma ideia, que na época foi muito boa. Meu marido falou para ele assim: "Olha, as meninas também não saíram da minha barriga, e elas não são minhas filhas? Então, você também é". Aí foi uma coisa que deu um alento.

(O pai tenta amenizar a dor do filho, e nesta situação prevalece a disponibilidade emocional dos pais.)

\section{(A) (Mãe 5)}

(Mesmo a mãe adotiva tendo contado a história da adoção ainda bebê, o filho naturalmente vive sua curiosidade infantil.)

(...) Aí depois, mais tarde, ele perguntou: "Foi daqui (barriga) que eu nasci, mamãe?" Eu falei: "Não, meu filho, não foi daqui que você nasceu". A minha cunhada dizia que foi, para a minha sobrinha, por isso ela levou o choque depois. Eu respondia para ele que não: "Você nasceu...". Aí tinha que contar: "... de uma moça, nasceu na barriga de outra moça, mas aí a mamãe pegou você. Você não lembra a história que a mamãe contou?"

\section{(B) Mãe 8}

Em relação a sexo, a gente conversa muito, ele tá com uma namorada de um ano, a gente já sabe. Eu falei: "Olha, tem que usar a camisinha, não pode deixar, porque senão acontece". E um fato da questão do adotado, ano passado ele chegou assim... já era época de Natal, a gente estava saindo junto, ele chegou bem discreto e falou: "Mãe, como se pega Aids?". Aí eu falei: "Olha só: sexual, drogas injetáveis, transfusão de sangue". Aí ele ficou parado, aquilo não satisfez ele. Aí, eu lembrei que a mãe pode transmitir para a criança também. E no caso dele poderia... Ué, ele é adotado, então poderia. Porque eu não saberia, mas eu já 
tinha feito o teste quando ele chegou. Aí eu falei: "Olha, meu filho, não se preocupe, que você fez o teste". Aí houve um alívio para ele. Percebi uma questão de preocupação para ele. Mas ele tem um cuidado comigo, que não fala. Aí, eu percebi que era isso. Aí, aliviou a questão dele. Que é uma questão que eu esqueci, né? Eu agradeço a Deus, porque eu não sei como eu tive essa sensibilidade. Eu olhei para ele e falei: "Hummm, tá faltando alguma coisa". Aí que eu lembrei que ele é adotado, porque às vezes eu esqueço. Aí eu lembrei que poderia ir $(a$ Aids $)$ pela mãe, né.

(C) (Mãe 4)

Era mais ou menos assim, a mãe dele vivia... Ele mesmo tinha trauma de bebida. Ele não podia me ver com um copinho de cerveja. "Mãe, você está bebendo!" Entendeu? Porque a mãe bebia e deixava os filhos com fome. Então, ele tinha pavor de bebida. Então, tem toda uma história, que não é à toa.

(D) (Pai 2)

Isso é interessante (as amizades)! Que ela sempre busca o grupo minoritário. Ela se sente protetora desse grupo. Sobretudo na escola dela, que tem muito estrangeiro. O grupo dela é venezuelano, paraguaio, boliviano... São essas minorias, ela está junto com as minorias, e defende.

(D) (Mãe 4)

Não pergunta. Não pergunta (sobre a família biológica). Ele vê... eu não sei se ele sente uma tranquilidade, porque nada é assim... criticado. Não se passa um peso nas coisas. Porque, por exemplo, ele adora a minha empregada. Ele se identifica muito com ela, ele durante muito tempo, hoje eu acho que menos, mas durante muito tempo, até hoje ele pergunta: "Ela tá? Não tá? Quando ela volta? Ela já chegou e tal?" Eu não sei se ele fica preocupado de passar fome, porque ela é que está lá. Ela faz comida e tal. Eu não sei o que é. Mas há uma ligação forte com ela. E aí eu fico brincando: "E aí, parece mais seu filho do que meu! Não é possível!". E ela é escura, ela é negra, e ele como é moreno para mulato. Então, digamos assim, a minha empregada, ela é negra, mas ela é filha de branco com negro. Ele adora ela! E aí eu fico assim: "Mas teu filho postiço tá querendo nananana...". Às vezes, ele quer ir com ela e eu tenho que brigar: "Não, não vai. Vai ter que ficar comigo (tom de brincadeira)". "Mas, por que que eu não posso (pergunta o filho adotivo)?". "Porque eu sou sua mãe, vai ter que ficar comigo. Eu já trabalho a semana inteira, para chegar no final de semana e você querer ir com ela de novo...".

(D) (Mãe 6)

O diretor da escola falou: "Eu sou diretor dessa escola há 32 anos. É um desafio, porque é um colégio de crianças, vamos dizer assim, normalmente muito ricas, muito abastadas, então, normalmente são crianças muito arrogantes, adolescentes muito arrogantes. E você está de parabéns, porque os teus filhos, mesmo você tendo um colchão maior...”. Eu brinquei: "Que colchão?". Ele falou: "Não, 
mesmo você tendo uma situação melhor, os teus filhos são pessoas simples, tratam todos muito bem, o faxineiro, o porteiro".

(D) (Mãe 8)

Então ele é assim articulado, é maduro. Ele ajuda as pessoas, ele tem esse olhar de ajudar os menos desfavorecidos. (...) Como a minha secretária, ele tem um carinho muito grande com ela, com as pessoas do prédio, os faxineiros, o zelador, ele conversa de igual para igual, dá bom-dia, boa-tarde. Ele se puder ajudar, ajuda. Ele até me pede, por exemplo, se sobra alguma coisa na festa, eu sempre coloco pro porteiro, ele faz questão de ele levar lá embaixo.

Talvez caiba a pergunta: será que, em filhos não adotados, esses fatores também estejam associados à origem? Acreditamos que sim. Certamente, como é muito explanado na literatura, em relação à curiosidade infantil e à descoberta sexual nos adolescentes. Como mencionamos anteriormente, cada vez que o saber é produzido, dá-se o paradoxo do encontro com o vazio.

Discutimos a partir do Mito de Édipo e das formulações de Brunetto (2008), que todo homem vive o drama edipiano, o inefável das relações objetais primárias, e o quanto a própria história primária lhe é estrangeira. O Édipo guarda a marca de sua origem em seu corpo (os pés inchados) e em seu nome (sua identidade), carregando a marca da exclusão eterna em sua origem. Lembremonos de Brunetto (2008) salientando que "todo sujeito é expatriado de suas lembranças mais antigas, necessitando reconstruir esses capítulos apagados de sua origem" (p. 74). Contudo, na condição adotiva esse vazio fica em carne viva e insondável. O estrangeiro é vivido de maneira concreta e imposto pela realidade à família adotiva, fazendo da condição de ser expatriado da origem uma violência à realidade do sujeito, pesando sobre a elaboração da condição de desamparo da existência humana. Dessa maneira o mistério com seu aspecto comparável ao "umbigo do sonho", conforme destacamos em Farias e Barros (2008), pertencente a qualquer história, facilmente pode torna-se um "sintoma" nas famílias adotivas.

Nos filhos que foram adotados ainda bebês, observamos que, durante a fase da curiosidade infantil sobre as origens, eles perguntavam explicitamente aos pais e falavam frequentemente sobre a adoção. Contudo, na adolescência houve uma mudança. Alguns dos entrevistados apontaram que os filhos, que antes se mostravam abertos para falar sobre a adoção, passaram, na adolescência, a explicitar o desejo de não tratar desse assunto. 
Criamos uma hipótese de entendimento para esse fenômeno descrito por alguns pais. Talvez esses adolescentes tenham deixado de falar naturalmente sobre a adoção por haver algum tipo de vivência emocional ligada à vergonha, ao ser diferente da família e da maioria dos membros seu grupo social. Como formulamos no capítulo quatro, os adolescentes paradoxalmente buscam a diferenciação e ao mesmo tempo a uniformização. Essa tendência fica explicitada na inserção do adolescente em grupos homogêneos, os quais funcionam simbolicamente como o colo materno (WINNICOTT, 1965 E PALHARES, 2008), mas também simbolizam a quebra da fusão entre pais e filhos, viabilizando a individualização. $\mathrm{O}$ silêncio dos filhos adolescentes descrito pelos entrevistados pode significar a dificuldade de lidar com aspecto "ser diferente" de seu grupo familiar e, talvez, de seu grupo de amigos, ameaçando sua propensão ao homogêneo para poder se diferenciar e ao mesmo tempo pertencer.

(Pai 2)

(Quando pequena, a filha perguntava sobre sua origem, e o pai estranha ela ter mudado de comportamento.)

Perguntou pequenininha. A gente contou que a pegou no hospital, que a gente não sabe o motivo. A gente contou isso, que a pegou no hospital. E que a gente foi lá buscar. A gente que escolheu ela. Ela foi es-co-lhi-da, né. Para dar esse sentimento. É legal isso. E eu falo com ela, frequentemente, sobre isso, toco nisso! Mas ela (agora na adolescência), não. Não evolui o assunto (tom de estranhamento, indagador).

(Mãe 3)

(...) Ele me perguntava: "Por que eu não saí da sua barriga?" Porque, quando ele ouvia a história, que um bebê saía da barriga, ele perguntava. Eu falei para ele que ele não saiu porque a minha barriga tinha defeito: "A minha barriga tinha defeito, aí papai do céu deu outro jeito de trazer você pra mim”. Tá errado ou não, mas eu sempre fiz isso. (...) O gozado era o seguinte: ele perguntava isso de vez em quando, quando era muito pequeno. Depois, nunca mais voltou nesse assunto. Não é que ele tenha esquecido, não. Mas é que os pais deles somos nós e acabou!

(Mãe 4)

Ele não gosta de falar de adoção, ele não gosta que eu fale. Quer dizer, na medida em que as coisas são colocadas de uma forma natural. Já tiveram vários programas de televisão, para fazer entrevista, para tirar foto, para fazer reportagem. Até isso, ele começou a crescer e ele é muito tímido, muito calado, ele quase não abre a boca, quase não fala. (...) Mas ele começou a não querer. Ele não queria mais falar sobre isso, era como se ele tivesse se incomodando com aquilo. 
A partir desses trechos, pudemos ver que, apesar de os filhos já terem ouvido sua história de origem desde cedo, eles não deixam de passar pela natural fase da curiosidade sexual infantil. Notamos que a questão da origem aparece de forma constante para essas famílias. É interessante que, nas situações descritas pela Mãe 1, Mãe 4 e o Pai 2, evidenciamos a sensibilidade deles ao perceberem o conflito dos filhos, legitimando-o e buscando alguma tentativa de compreensão. Isso ilustra a disponibilidade emocional dos pais, a qual parece fortalecer o senso de pertencimento familiar entre pais e filhos.

Talvez seja nas famílias adotivas que podemos entender com mais clareza as contingências das incógnitas sobre a origem no processo de subjetivação do sujeito. Na filiação adotiva, as questões da origem são passíveis de serem identificadas, já que estão presentes nos questionamentos sobre a diferença de cor de pele e de cultura, o nascimento na barriga, os vínculos de identificação. Vimos que na adolescência o mito de origem aparece na questão da sexualidade. Os entrevistados afirmam falar sobre sexo com muita liberdade, ficando atentos às questões que surgirem, e por meio de uma escuta psicanalítica, sabemos que falar de sexo toma um significado inconsciente de se falar da origem, da cena primária.

Outros dois pontos chamaram a atenção, dentro desta categoria, pela repetição e semelhança no discurso dos pais. O primeiro ponto diz respeito à busca por tratamentos com divergências de diagnósticos. Identificamos que todos os entrevistados procuraram tratamento psicológico para seus filhos, alegando diferentes razões (esta questão será detalhadamente discutida na categoria Rede de apoio). Em quatro dos entrevistados, houve a descrição de terem sofrido com as discordâncias de diagnósticos e em indicações de tratamentos para seus filhos. $\mathrm{O}$ segundo ponto corresponde à experiência dos filhos adotivos em situações de bullying na escola.

Perguntamo-nos se este dado estaria relacionado a uma tendência dos profissionais de saúde a uma patologização da adoção. Como não temos subsídios suficientes para balizarmos a resposta a tal questão, propomos confrontar esse dado com a literatura estudada. Conforme Marinopoulos, Sellenet e Vallée (2003) explicam, para pais adotivos, a origem do filho constitui um buraco narcísico, e esta realidade provoca tanta dor que os obriga a se protegerem, por meio de mecanismos como spliting e negação. 
Talvez os pais, na busca por soluções e entendimento de sintomas, inconscientemente esperem dos profissionais de saúde respostas para as incógnitas que permeiam a origem de seus filhos. Pode ser que, ao buscarem respostas em diagnósticos e em evidências científicas para situações que lhes são inexplicáveis, estejam querendo saber "quem é meu filho?, por que ele é assim?" ou "que mãe e pai sou eu"? Pensar dessa maneira seria coerente com o que analisamos, nos discursos dos entrevistados, sobre a ambiguidade e a ambivalência presentes na constituição da parentalidade adotiva, desencadeando dúvidas sobre que tipo de pai e mãe eles são. Estariam os profissionais de saúde ocupando o lugar dos oráculos na fantasia dos pais, como no mito de Édipo? Que papel é dado aos profissionais de saúde? Que respostas inconscientemente são esperadas?

(Pai 2)

(...) ela foi para a terapia. Ela já está na terceira. Nós erramos nas escolhas. Uma diagnosticou que ela tinha uma dislexia. Aí depois, a outra dizia que ela tinha DDA. Aí essa (a terceira) não diagnosticou nada. Ela tem uma leve DDA. Eu levei numa neurologista séria. E ela tem uma coisa mínima, que ela tem que conviver. Como é? Hiperatividade, porque está sempre associado o déficit de atenção à hiperatividade. Ela tem um pouco dessa hiperatividade, (...) e se atrapalha quando tem duas ou três tarefas, ela fica meio perdida. Mas isso, se eu te disser, eu também sou.

(Mãe 1)

Como a vida inteira ele fez fono, fez terapia, por conta desses problemas de socialização, dificuldades no aprendizado. Ele tem dislexia. Tem DDA. Então, a gente sempre foi cercando de todos os lados para entender todos os problemas. Então, ele também chegou a perguntar às vezes: "Então eu faço terapia e fono porque eu sou adotado?". Às vezes, ele associava as coisas. Então, até hoje ele faz terapia. Hoje ele faz uma terapia voltada para DDA. Toma Ritalina por conta da DDA e da hiperatividade. Tem um óculos especial para dislexia. (...) Sempre tinha alguém que dizia assim: "Tem um traço de dislexia, mas não é o disléxico clássico", "tem um traço de hiperatividade, mas não é o hiperativo clássico", e no final ele não era... ele era o clássico. Entendeu?E depois agora que eu fui descobrir a historia do óculos, que ele fez testes específicos, não só de oftalmologia. E testes de aprendizado com a lente especial e sem a lente especial.

(Mãe 3)

Com 5, 6 anos ele ficou muito depressivo! Uma agressividade, porque ele era muito levado, arteiro. E ele tomou remédio controlado, inclusive na época o pediatra dele indicou outro neuro. (...) Deu o diagnóstico errado. (...) Na época ele fez vários exames e deu uma alteração. Então ele começou a tomar o remédio. E junto com o médico ele começou a fazer terapia, com 5, 6 anos. Fez terapia por 
três anos. Aí acabou a terapia. Nisso que acabou a terapia, eu que tinha o meu cunhado médico, pedi que arrumasse outro bom médico para que avaliasse o meu filho. Depois esse médico falou: "Eu rasgo o meu diploma! Esse menino não tem nada. Essa alteração no eletro, há anos atrás se diagnostica de uma forma, hoje não. Vamos tirar o remédio". Até aí foi tudo tranquilo. Ele nunca foi de perguntar muito. De vez em quando, ele me perguntava: "Mãe, você sabe o que eu tive"? Aí expliquei toda a situação que eu não sabia.

(Mãe 7)

Ele não é muito acadêmico, acho que não vai ser um médico. Ele tem DEL. DEL é tipo uma dislexia. Que é difícil para ele. É muito difícil para ele. Ele faz fono. DEL é um distúrbio específico da linguagem. É da família da dislexia, mas é pior! O problema é na leitura, nos fonemas e na interpretação, tem muita dificuldade de interpretar. Ele tá bem treinado, porque está bem trabalhado, mas tem muita dificuldade em interpretação, na troca de fonemas, de palavras parecidas.

Falamos mais acima sobre a dupla fidelidade do filho adotivo e sobre a dupla origem (uma biológica e outra afetivo-imaginária, construída na família adotiva). Associamos esta ideia aos sintomas mencionados pelos pais, como a dificuldade de realizar a dupla tarefa de interpretar e concomitantemente precisar entender a dupla fidelidade. Arriscamos pensar que haja alguma relação entre esses sintomas e a história dupla vivida por essas famílias.

Muitos podem vir a pensar assim: por que aproximar esses sintomas das origens? Nem tudo tem a ver com o ato da privação biológica e com o ato da adoção. Aos que se identificam com esse tipo de interrogação, respondemos que realmente nem tudo está relacionado a esses fatos, mas no momento em que os próprios envolvidos já os associam à questão da adoção, sabemos que para o inconsciente não há negativa. Por isso acreditamos que realmente seja preciso uma lente especial para observar a dinâmica inconsciente dessas famílias, de modo a não cairmos na patologização, nem tampouco na banalização.

Defendemos o argumento de que a trama adotiva não é inócua, apesar de os pais muitas vezes insistirem em caracterizá-la como tal. Neste movimento vemos as defesas em plena atividade para aplacar as fantasias, já que os pais acabam desconsiderando emocionalmente a situação externa que potencializa determinadas questões. Negar este caráter é pouco produtivo psiquicamente, como temos visto pelas entrevistas.

Com relação à experiência do bullying, devemos nos interrogar se, ao viverem isso, esses adolescentes não revivem algum tipo de sentimento em relação à fantasia de terem sido rejeitados pelos genitores biológicos. O bullying 
nada mais é do que sofrer a violenta rejeição por parte de seus pares. Estariam esses jovens, movidos pela compulsão à repetição, colaborando inconscientemente para ocuparem o lugar de desamparado? Será que agem inconscientemente para que a fantasia de terem sido rejeitados pelos genitores seja confirmada?

(Pai 2)

(O pai contou que quando a mãe adotiva de sua filha morreu, a filha sofreu bullying na escola, e por isso ele escolheu outra escola para ela estudar.)

Mas, em compensação, quando eu a transferi para a escola $\mathrm{X}$, eu senti que eles estão extremamente preparados para lidar com o bullying. Tem escrito em todos os corredores sobre isso: "Evite", "Trate bem seu colega", "Aceite seu colega". Tem uma cultura de aceitar o diferente. Que são muitos estrangeiros...

(Mãe 3)

Agora aconteceu um problema também, que talvez te ajude em alguma coisa. Eu tenho uma amiga que é psicóloga, e ela me deu muito apoio nessa época. Nós tivemos um problema muito sério com ele no segundo ano do ensino médio. $\mathrm{O}$ meu marido fez um escândalo na escola, por conta de um professor. Ele falava pra turma que eram uns ignorantes, uns incompetentes. Então, aquilo me irritou, e meu marido fez um auê, fez um escândalo. (...) E essa minha amiga falou que a gente tava certo: "Vai lá, deixa seu marido fazer, porque ele (o filho adotivo) precisa de vocês agora. Isso vai unir muito ele a vocês, porque ele vai ver que, no momento mais difícil, o pai batalhou".

(Mãe 5)

Porque teve uma escola que ele sofreu muito bullying nesta escola. E uma vez, eu falei para ele que ele tivesse cuidado. Isso ficou na cabeça dele para sempre. Eu falei que ele tivesse cuidado se fosse brigar com alguém. Mas, no fim eu já estava mandando ele brigar, porque eu achava que ele era muito forte, e que ele tivesse cuidado com a força que tinha. Ele ficou com aquilo na cabeça, e começou só a apanhar, e não batia em ninguém, porque ele tinha que ter cuidado com a força que ele tinha, entendeu? Aí eu fui na escola, e teve uns probleminhas mesmo lá.

Devemos destacar que levantamos estas questões a partir de uma perspectiva de Winnicott (1971), por meio da qual ele entende que muitos dos problemas que aparecem não são consequências da adoção propriamente dita, mas sim de como cada sujeito poderá significar sua história e da capacidade de continência para seus conflitos promovida por seu ambiente familiar. Conforme mencionamos anteriormente, Winnicott (1971) defende a ideia de que os pais 
adotivos devem encarar o fato de se tornarem pais de uma criança com carências básicas, e que necessitaram por vezes de que exerçam um papel até terapêutico. Complementamos esta concepção, com ideia de Rotenberg (2011) que traz o entendimento de que somente o vínculo amoroso/terapêutico será possível mitigar as possíveis atuações compulsivas de tornarem as fantasias concretas e os confrontos que busquem colocar à prova o amor daqueles que são próximos.

\subsubsection{Identificação e identidade}

Pensamos os genes como os representantes narcísicos no psiquismo dos pais (LEGENDRE, 1985). Entendemos com essa ideia que, por meio da representação genética, os pais podem se reconhecer nos filhos, como se existisse alguma "garantia" da presença de uma parte deles mesmos no filho, da sua herança, e assim patrocinando a fantasia de infinitude. Percebemos, a partir das entrevistas, uma necessidade de reconhecer alguma semelhança nos comportamentos e nos traços de personalidade para ser criada uma identidade de parentesco. Talvez esses sejam os representantes metafóricos do narcisismo dos pais na adoção, sendo aquilo que os faz lembrar: "Ele é uma parte de mim, logo é meu filho". Pudemos ver que este desejo não pertence somente aos pais. Por vezes, os filhos adotivos também demandam se reconhecerem nos pais. Como na cena do filme britânico Greystoke - A lenda de Tarzan (1984), na qual o Tarzan olha para seu reflexo na água e para o reflexo de sua mãe Chipanzé e, percebendo a diferença de cor de pele, se lambuza de lama.

(Mãe 5)

Ele já foi gordinho quando era pequeno, agora não, ele ficou esguio, ficou mais magro. E ele queria ter os cabelos lisos igual aos meus, ele fala. Porque o cabelo dele é ruim, né? É bem ruinzinho. E essas coisas assim ele tem. Ah, ele tem os probleminhas dele, porque ninguém é perfeito, né? Então ele tem os traumazinhos dele, ele tem porque ele acha que ele é feio.

Talvez, o carregar/abrigar um filho na barriga receba um sentido semelhante ao que estamos propondo sobre os genes: "Ele veio de dentro de mim". $\mathrm{Na}$ formação da parentalidade dos pais adotivos não é possível contar com essas experiências calcadas no eu corporal. A mãe que adota precisa instituir outra 
forma de reconhecimento do filho, já que não tem acesso ao preparo da gestação. Ela precisa desenvolver outros recursos para ter sucesso em sua função materna (ABRÃO, 2011). Faz-se necessário que, para reconhecer e compreender o filho, ela crie meios que se sobreponham e substituam as representações da gravidez e da experiência de dar à luz o filho. Logo, a representação do filho adotivo, no imaginário da mãe, não parte da representação de seu ego corporal, uma vez que essa criança não saiu de seu corpo.

Abrão (2011) observa que a mãe adotiva, por não ter os registros das necessidades do filho emanadas de seu próprio corpo, não pode recorrer às sensações da gravidez para constituir-se como mãe. A autora considera que, se a mãe adotiva insistir no caminho da identificação pela via corporal, isso será uma falta, que se transformará em sintoma. Consequentemente, a mãe adotiva poderá contar apenas, neste encontro inicial, com os referenciais primários de sua própria experiência precoce. Caso a mãe adotiva não esteja convencida da capacidade de compreender as necessidades do filho, por exemplo, por estar presa à falta corporal, mais fácil se instalará a dificuldade de comunicação entre os dois.

Para Marinopoulos et al. (2003), o encontro do filho imaginário com o filho real é a passagem de um investimento narcísico para um investimento objetal, acompanhada de reformulações, de perdas e de desencanto. Destacamos, aqui, a função essencial da identificação para a consolidação do vínculo parento-filial. A identificação torna-se o elo emocional imprescindível entre os pais e seus filhos adotivos. Talvez por ser através da identificação que o filho real, representante do enigma, do estranho, tão aterrorizante para os vínculos afetivos de modo geral, possa se aproximar do filho familiar, do filho reconhecível por sua semelhança.

No discurso do Pai 1 e da Mãe 2 podemos ver a exaltação das identificações muito claramente. Eles valorizavam bastante as semelhanças entre eles e os filhos adotivos, não mencionando espontaneamente as diferenças.

(Pai 1)

Mas transaciona muito, porque eu faço música e ele toca piano, compõe. A gente grava e coloca as coisas na internet, estas coisas todas. Então... E a gente transaciona muito por essa coisa por aí. E gosta de jazz, eruditas, clássicas. Ele compõe no computador, um negócio incrível. 
Então ficou... foi uma coisa que, às vezes, nem tem perda. De modo que não houve o trauma da separação. A gente convive bem. É muito companheiro. A gente gosta das mesmas coisas.

(Mãe 2)

E uma coisa muito interessante, que quem não conhece... Amigos meus que eu não vejo há muitos anos, ou pessoas que fazem parte do nosso convívio só agora. Ela fala abertamente na questão da adoção e eu também. Não temos nenhum problema para falar sobre isso. Mas, quem não conhece, não diz que ela não é filha biológica. Ela adquiriu muita característica nossa. Até quando ela atende o telefone, assim, a voz: "É a filha ou é a mãe que está falando?" O jeito mesmo de tratar as pessoas. (...) O pai dela, meu marido, de princípio parece uma pessoa muito reservada, mas é muito brincalhão e ela pegou todo o jeito brincalhão.

Notamos que, na história da Mãe 3, reconhecer alguma semelhança foi fundamental para despertar o desejo de vincular-se àquela criança e, assim, semear a identidade parental.

(Mãe 3)

(Quando ela foi ao hospital conhecer o bebê que possivelmente adotaria, notou algumas características físicas que são semelhantes às do marido. Ela mesma não associa conscientemente isto, mas tive a oportunidade de conhecer este casal de pais pessoalmente e observá-los.)

O que me impressionou muito era porque ele era loiro! Não é pelo fato de ser branco, nada disso. Mas por ele ser loiro, e só aparecia a mão dele, porque era imensa a mão dele (o pai é uma pessoa muito alta) $\mathrm{Eu}$ até falei para ela (enfermeira), ele vai ser uma pessoa alta, com $2 \mathrm{~m}$ e pouco de altura, porque ele era muito grandão.

(O marido falou) "Se for para adotar o garoto, está adotado!" (...) Eu em princípio falei para a enfermeira, ela queria que eu pegasse ele. Porque eu fiquei com muito medo de não conseguir ficar com ele. Então eu não podia, eu não queria chegar assim: "É meu! E de repente não seria meu". Aí, ela falou para mim: "Ele é seu, ele vai ser seu filho, já está escrito". Aí, entra a religiosidade.

No discurso da Mãe 6, observamos que há o uso da identificação como uma defesa da angústia gerada no enfrentamento da doença de seu filho mais novo.

(Mãe 6)

Falando em palavras leigas, é como se fosse um tumor... o risco é ter um derrame. Como no caso dele é enorme... Por ser muito grande, temos um problema: não é operável. Mas o último médico que eu fui... me disse que a chance dele ter um 
derrame é de 0,1\%. Eu falei: "Então, meu filho, viver a vida normal!" (...) Os médicos acreditam que isso aconteceu geneticamente, enfim... Mas, no caso dele, a mãe biológica, quando estava grávida, trabalhava em uma boate de beira de estrada, e quando os caminhoneiros paravam ali, a obrigação dela era fazer com que eles pagassem uma bebida para ela e uma para eles. E ela ganhava por bebida consumida. Muito provavelmente, ela grávida, o álcool, como é vaso dilatador, rompeu uma daquelas veias que estava se formando no primeiro trimestre de gestação e formou essa má-formação arteriovenosa. (...) Mas a do cérebro é uma coisa impressionante, porque o meu avô, pai da minha mãe, meu avô biológico, ficou cego aos 26 anos por ter o mesmo problema do meu filho. No mesmo tamanho e no mesmo lugar. Você vê que, o que você tem que passar, o vizinho não leva. (...) E um primo do meu marido também... Você vê que, talvez, nós fôssemos passar por isso de qualquer jeito, caso fosse genético. Porque existe uma corrente que diz que isso é genético e existe outra que diz que isso não é genético. Mas o fato é que... o meu filho tem e descobrir isso não foi fácil.

Como abordamos, a identificação foi formulada por Freud para qualificar um processo que constitui e transforma o sujeito, e pelo qual ele se apropria de atributos ou traços de pessoas, em determinados momentos de seu desenvolvimento. O processo de identificação participa não só da constituição da subjetividade, mas também da constituição das relações objetais. Sendo assim, a identificação marca o futuro do vir a ser, portanto, do senso de identidade.

Concebida como uma expressão primária de um laço emocional com outra pessoa, a identificação também corresponde à ação de se reconhecer como algo ou alguém, considerando a semelhança entre os objetos (EIGUER, 2012). A questão da definição de um perfil de criança desejável para os candidatos à adoção também esbarra na identificação possível que cada um possa criar, ou seja, deve haver elementos que permitam a semelhança entre o eu e o não eu.

Lembremo-nos de Freud (1913-1914) quando destaca a noção de parentesco, diferenciando-a da noção de vida familiar. O parentesco é definido, segundo o autor, pelo asseguramento da semelhança entre seus integrantes. Defendemos a ideia de que, para a formação da parentalidade adotiva, o asseguramento da semelhança tem um papel importante na constituição da identidade de parentesco e na manutenção do vínculo entre pais e filhos adotivos.

Lembremos, mais uma vez, a alusão feita por Freud (1921) à experiência dos porcos-espinhos. Esses animais criam um espaço intermediário, no qual podem suportar os espinhos e aproveitar o calor de seus corpos. Pensamos que, da mesma maneira, os sujeitos vivenciam subjetivamente a busca de uma distância ótima intrínseca às relações. É como se, na falta do biológico, outros elementos 
patrocinadores da semelhança precisassem entrar em ação de forma intensa, para garantir a semelhança e o pertencimento. Dessa maneira, é como se estivesse garantido um espaço ótimo entre o estranho e o familiar.

(Mãe 5)

Tem que falar porque... eu vou te mostrar o retratinho dele. Porque, quando ele era pequenininho, as pessoas falavam: "Ah, ele é adotado, né, porque meu marido é italiano e ele é mulato, o meu filho". Entendeu, então não tem como mentir!

$\mathrm{Na}$ adoção tardia observamos que as diferenças e o não reconhecimento do filho já trazem um lastro maior. Os filhos carregam significados específicos tanto da cultura familiar de seus genitores quanto das experiências passadas, verbalizando-as com mais clareza.

(Mãe 2)

(A filha foi vítima de boatos de ter sofrido abuso sexual.)

(...) Primeiro eu fui levá-la nos médicos, ao ginecologista, levei ela numa especialista em violência sexual, para ir investigando tudo que estava se passando e tudo que poderia ter se passado com ela. (...) Eu tive que ir aos pouquinhos, eu já tinha sido orientada até por uma psicóloga amiga minha, que não a conhecia, mas que quando eu mencionei o que se passava, ela falou: "Conforme ela for percebendo a confi... ir criando laços de confiança. Ela mesma aos pouquinhos vai te revelando. Não vai ser tudo ao mesmo tempo".

(Mãe 4)

E ele tinha muita raiva de mim, que era mãe! Porque ele tinha muita raiva da mãe dele. Porque o pai dele, o pai que gerou, ele via de uma maneira muito boa, porque o pai era uma pessoa boa. O pai era aquele cara que deveria vender... sei lá se era camelô. Então, volta e meia dava bala, dava um dinheirinho, dava não sei o quê. Mas, na hora que ele foi para o abrigo, o pai em momento nenhum foi no abrigo. O pai em nenhum momento o tirou do abrigo. Então, isso depois ele trabalhou na terapia, que imagem era essa de pai que ele faz que na hora $\mathrm{H}$, quer dizer, o pai não era melhor do que a mãe. Mas ele não tinha uma imagem ruim do pai, masculina. Agora, ele tem uma imagem ruim da mulher. A mulher, ele tem uma imagem péssima. Ele tinha horror a essa mãe. Então, consequentemente, eu representava a mãe, eu era a mãe!

(Mãe 6)

Porque a (primeira filha adotiva) era um pequeno ser que não sabia nada. Eu me lembro que eu mandei fazer a primeira refeição, mandei fazer normal, arroz, bife, feijão, batata frita ou um purê de batata, alguma coisa que tinha lá. E ela pegou o pratinho e sentou no chão. Eu falei com ela: "Vem comer na mesa". Aí ela falou: "Criança come no chão". Aí meu empregado falou: "É porque lá (na cidade natal 
da menina) as crianças comem no chão. É a cultura". Eu falei: "Não é questão de cultura, é que são casas pequenas, com famílias enormes, e na mesa cabe o casal e os avós, e as crianças pegam o pratinho e vão para o chão. Mas aqui tem uma mesa enorme para um casal e ela vai comer na mesa". Eu me lembro que eu mandei vir uma cama linda e ela disse assim: "Durmo nisso não". "Mas por que não, numa cama linda?" Tinha um ursinho cravado na madeira... "Olha que urso lindo", eu falei. "O urso é lindo, mas eu só durmo na rede". Aí, meu marido falou: "Vamos, comprar uma rede". "Não vamos comprar rede nenhuma! Vai dormir na cama". E assim foi. No começo, ela queria comer feijão com farinha no café da manhã, almoço e jantar. Primeira vez que viu um danoninho abriu um berreiro. Foi um chororô...

Como mencionado, na adoção precoce ou tardia, é uma ilusão achar que o filho adotivo não trará consigo os registros de sua história de origem. Podemos observar que os pais fazem o que podem para lidar com esses lastros. O que os pais devem entender e elaborar psiquicamente, como na situação explicitada pela Mãe 6, por exemplo, é que quando a filha lhe diz que comerá no chão, ela expressa a criação dela e com isso aponta a mensagem suprimida: eu não sou como vocês e serão vocês que deverão me inserir na sua cultura. Os pais se depararam com uma trabalhosa e atenta tarefa de inserção do filho adotivo em outras representações. E esta tarefa não pode ser desconsiderada, como na situação da Mãe 4, que precisa viver com seu filho um outro tipo de relação objetal materna para que novos significados sejam inseridos.

Talvez possamos pensar que o excesso na busca pela semelhança, como uma forma de manutenção do elo familiar, venha a comprometer a suportabilidade na confrontação com as diferenças, com o singular. Esse excesso revela a precariedade em lidar com o irreconhecível, com o estranho. Conforme foi mencionado, Dolto e Hamad (1998) entendem ser necessário que os pais adotem a singularidade da criança e permitam que ela seja feliz, podendo ser cada vez mais ela mesma e viver de maneira mais integrada tanto com os seus velhos quanto com os novos registros. Desse modo, ela terá condições de realizar a dupla tarefa, as interpretações de sua história, como vimos na categoria anterior, e assim evitar a produção de sintomas.

Para Eiguer (2008), o reconhecimento do outro, em sua singularidade, permite a separação. $\mathrm{O}$ autor sublinha que esse movimento de reconhecimento é contraditório e paradoxal, uma vez que o reconhecimento do outro leva à 
percepção do lado obscuro deste, e por isso nunca é completo. Essa incompletude induz o sujeito a se defrontar com o enigma do outro, com aquilo a que não se tem acesso, portanto, com a castração.

Propomos pensar que talvez todos os pais adotivos vivenciem, de certa forma e em algum momento, essa necessidade de fortalecer as semelhanças, negando assim a concomitância da diferença. Contudo, realçamos que se a diferença for desconsiderada, os vínculos de pertencimento se tornam frágeis, e a busca pela semelhança passa a ser predominantemente uma rígida defesa, em vez de um elemento que semeia a identidade de parentesco e a manutenção dos vínculos.

(Mãe 1)

(O filho estudava em uma escola à qual estava muito adaptado, mas a mãe o transferiu para a escola onde estudaram as filhas biológicas.)

(...) Depois eu mudei ele de escola, e acho que foi um marco muito ruim na vida dele, onde as minhas filhas tinham estudado. E eu ouvi na época críticas: "Por que você vai mudar, se ele está tão bem nessa escola?" Eu tinha receio de que se eu fizesse alguma coisa diferente pudesse parecer que ele tinha sido tratado como um filho adotivo. Então, eu queria fazer tudo igual. Então, se as meninas estudaram nessa escola, eu queria que ele estudasse nessa escola. Eu não queria que mais tarde ele perguntasse por que ele não foi pra escola $\mathrm{X}$. E foi uma bobagem minha. Mas, na ânsia de não errar, você acaba errando. Quando você fica nessa coisa de não fazer a diferença, eu tinha que ter a consciência de que eu não fazia a diferença. Era meu filho e pronto.

É igual como se ele fosse meu filho nascido de mim. Eu não tenho... não noto diferença.

(Mãe 4)

Às vezes, a gente quer ajudar, e às vezes, a gente peca, que nem filho mesmo. Que nem filho, eu quis dizer assim, que teve, gerou, gestou, ficou nove meses na barriga, você quer o melhor, mas muitas vezes você erra. Não posso dizer que não errei, e aí? Só que, às vezes, o tempo já passou e você vai fazer o quê? Por exemplo, quando o (filho adotivo) chegou, ele tinha 7 anos, ele chegou em outubro, ele não estava alfabetizado. Ele tinha 7 anos e não estava alfabetizado, e não sabia ler. Aí eu falei, poxa ele tem oito e vou colocar na alfabetização? Um ano de alfabetização... um ano de primeiro ano... entendeu?! Ele ia sair da alfabetização com nove anos. Vai entrar no primeiro ano com 10 anos. Aí, o que eu fiz? Rapidamente eu arranjei uma escola pequena que uma sobrinha minha tinha estudado, e arranjei as professoras e combinei delas alfabetizarem ele em novembro, dezembro, janeiro e fevereiro para ele entrar no primeiro ano alfabetizado. E assim foi, ele se alfabetizou em quatro meses, nesta base, e entrou no primeiro ano. Mas talvez fosse melhor se ele tivesse feito, alfabetizado... É 
complicado! Os quatro anos (escolares) ele teve reforço. Hoje ele tem três professoras de reforço. Três!!!

Tanto a Mãe 1 como a Mãe 4 se deram conta de que negaram as singularidades de seus filhos, as marcas do desconhecido, da descontinuidade, do inicial não pertencimento à família adotiva. Apesar de as intenções de ambas terem sido benignas, elas negaram a realidade que se impunha. Como o fato de o filho da Mãe 1 estar bem adaptado à sua escola e não precisar ir para a escola das irmãs. E como na situação do filho da Mãe 4, que de fato estava atrasado em seus estudos e a correria revelou-se mais uma questão burocrática do que um propósito de aprendizado.

Notamos que muitos dos entrevistados passaram por esta experiência de negar a singularidade da criança, as descontinuidades na vida da mesma e as diferenças na experiência de ser pai adotivo. Alguns, temendo discriminar seus filhos, intensificam a negação das diferenças. Outros demonstram isso reforçando excessivamente a igualdade entre parentalidade biológica e parentalidade adotiva, como, por exemplo, quando afirmam que é igual o amor aos filhos biológicos e aos adotivos. No entanto, sabemos que não se trata de amor igual, mas sim de gradações das afinidades e das fantasias existentes.

\subsubsection{Rede de apoio}

Descrevemos que autores como Souza e Casanova (2011) destacam a concepção da família extensa como uma rede de apoio muito significativa na preparação da chegada da criança, legitimando o lugar da mesma na cadeia geracional e recriando mutuamente os papéis e as funções familiares. No entanto, com base nos dados das entrevistas, observamos a presença de uma oposição a este pensamento. Os pais entrevistados foram unânimes em considerar que o posicionamento familiar não influenciou em sua opção pela adoção. Para os sete entrevistados que eram casados na época da decisão, a escolha da adoção foi determinada apenas por um consenso entre os membros do casal. Parece haver, portanto, uma diferenciação feita pelos pais entre a tomada de decisão e a legitimação do lugar da criança na família. Notamos isso, com muita clareza, nos trechos abaixo. 
(Pai 1)

Falavam que eu não deveria arrumar sarna pra me coçar... Amigos e pessoas da família também. Não digo as avós, nunca transpareceram, nunca me fizeram sentir isso. Mas, assim primos distantes, disseram: "Vocês são malucos, isso pode dar problema, vocês não sabem a origem, tem tantas histórias aí". Aí já inventam... Mas depois... hoje ela é superaceita na família, ninguém percebe, eu não percebo nenhuma discriminação assim. Muito pelo contrário. Mas era muito tabu.

(Mãe 1)

O meu cunhado, irmão do meu marido, já tinha uma filha adotiva. (...) Eles sempre partiram do princípio que ele ia ficar (que o filho iria ficar quando fora acolhido). A minha mãe trata ele assim: "É neto igualzinho". As minhas cunhadas todas. Os primos. Ele só não teve essa aceitação dos avós paternos. Até hoje eles fingem que aceitam... eles têm dois filhos... Os dois filhos têm filhos adotivos.

(Mãe 6)

Bem, a minha família (aceitou a adoção) um milhão por cento bem. Claro que, quando eu comuniquei que eu ia adotar três irmãos, todo mundo me chamou de louca. Meu pai falou: "Vou te pagar uma terapia, porque você perdeu o juízo!" Me levou no psiquiatra dele, falou pra conversar comigo. Porque ele estava fazendo terapia com o psiquiatra. E eu falei com o cara: "Eu não estou botando o assunto em discussão familiar. Estou comunicando que eu estou adotando três irmãos".

(Nessa época ela já tinha uma filha adotada.)

Para os que estavam solteiros, o fator crucial foi o próprio desejo, também não sendo decisivas as opiniões da família. A Mãe 5, por exemplo, queria adotar com seu companheiro, com quem tinha uma relação estável, apesar de morarem em casas separadas. Mas ele não quis adotar e ela adotou sozinha. Mesmo depois de morarem juntos e formarem uma família, o atual marido somente tomou a iniciativa de perfilhar o "filho" adotivo quando este estava com 18 anos.

(Mãe 5)

Aí, menina, eu fiquei tremendo de medo (quando soube que havia um bebê para adotar). Eu fui falar com meu chefe. (...) Ninguém sabia que eu (tinha se candidatado para adoção)... Eu não falava nem com o (marido). Ele dizia que não queria. (...) Eu voltei para casa naquele dia, porque eu ia no dia seguinte. Fui falar com ele. Ele falou: "Você vai perder o marido, porque eu tenho uma mulher 24 horas por dia, e eu não quero abrir mão disso que eu tenho". Falou mesmo! Para ele é assim: "Eu já tenho uma filha e não quero mais filho". (...) eu fui 
dormir, não sonhei com nada, mas no outro dia acordei com a certeza que iria perder meu marido. Eu falei para ele: "Eu vou". Ele não acreditou: "Você não vai, você vai perder o marido”. Eu falei: “(...) eu estou com as passagens na mão, eu vou embora".

Pudemos ver que a família extensa não é tida como um elemento essencial na tomada de decisão da adoção. Todavia, depois de consumada a adoção, a maneira como o grupo familiar lidou e se vinculou ao recém-chegado foi levada em consideração por esses pais. Isso corrobora a afirmação de Marinopoulos et al. (2003) de que, inegavelmente, a família como um todo participa do processo de integrar a criança à cadeia genealógica. Ou seja, embasados nos dados que obtivemos, a família extensa é indispensável para a integração da criança à família, mas não relevante na decisão da escolha. A sequência da fala da Mãe 7 serve como ilustração de nossas colocações.

(Mãe 7)

Porque muita gente se queixa que: "Não, porque o povo tem preconceito, a família não aceita, os pais e a família extensa, é difícil”. Eu acho que é muito da colocação que a pessoa tem. (...) Porque assim, eu acho que muitas pessoas não aceitam o filho adotivo como um filho inteiro, como um filho de primeira linha, ou não viveram o... Porque a gente tem $70 \%$ das pessoas que adotam não poderiam ter filho. Muitas não viveram esse luto, essa frustração e aí resolvem... a última saída é adotar. Eu adotei porque eu quis adotar outro filho. Eu não tinha problema nenhum, eu poderia ter tido dez filhos biológicos. Entendeu? Eu adotei porque eu quis (ênfase)!!! Não veio porque eu queria um filho e não podia ter. A maneira como a pessoa coloca este filho na sociedade é a maneira como a sociedade vai responder. (...) Por exemplo, a minha mãe é nordestina, a minha mãe não queria. Nordestino é o povo mais preconceituoso que tem. (...) E minha mãe não queria, nem...: "Filho dos outros? Vai criar filho dos outros?" Mas a postura que eu tive em relação ao (filho), não deu nem chance de... Podiam até não gostar dele, mas eu não... Mas o respeito foi desde o primeiro dia. Então assim, a minha família aceitou muito bem. Tirando a minha mãe, que eu dei um desconto porque já era mais velha e nordestina. $\mathrm{O}$ meu irmão teve uma certa... Não que ele tenha feito algo explicitamente. Mas, nas entrelinhas, você via queee... Mas, no final, é o tio queee... Porque, um ano depois, ele teve um filho temporão também, e o filho (do irmão dela), desde pequenininho, o meu era um ídolo para ele. Apesar de o meu irmão morar em X, agora mesmo o meu sobrinho chegou e tá lá em casa. São amicíssimos, se amam, então, não teve muita alternativa para o meu irmão. Chegou uma hora que ele teve que se render, entendeu? E, assim, é um tio superpresente, o (filho adotivo) ama ele. (...) O (filho adotivo) sabe que o lugar dele é aqui, que tem um lugar nessa família, que essa é a família dele. Ele também tem uma postura de como se colocar diante da família. 
A adoção na minha vida é uma coisa que eu nem falo, assim uma hora ou outra que ele pergunta, mas tranquilo.

Como foi apresentado no quadro biográfico, quatro dos entrevistados já tinham filhos biológicos antes da adoção, destacando-se o caso da Mãe 6, que já tinha uma filha adotiva quando adotou três irmãos. No discurso desses sujeitos observamos uma semelhança, que foi a participação dos filhos na chegada do adotivo. Por exemplo, seja na escolha do nome, na arrumação do quarto, no desejo de adotar aquela criança específica. Pensamos que, dessa forma, os pais incluíram seus filhos no projeto da adoção, dando importância à participação deles, permitindo a germinação da vinculação fraterna no psiquismo do filho. Isto corrobora com as pontuações de Ducatti (2004), porque intuitivamente os pais tomam uma atitude que transforma a criança adotada, que não compartilha o legado genético, em um elemento comum ao grupo, a partir da criação de uma aliança fraterna. Em consonância com essa perspectiva, supomos que os laços de parentesco na adoção são unicamente simbólicos, por isso o grupo familiar se insere como um fator continente ao sustento da filiação imaginário-afetiva. Segundo Filho (2009), são os avós que introduzem o neto na genealogia da família, validando a ascendência do filho adotivo.

(Pai 2)

Hoje ela tem os irmãos que superacolheram ela. Eu fiz, quando a gente decidiu adotá-la, eu chamei os dois, eles eram um pouquinho pequenos, uns 10 anos. E a (filha mais velha) tinha 13 e o (filho do meio) 10. Aí, eu quis falar o que ia acontecer, né. Vibraram! E o nome que nós queríamos, eu e minha mulher, era Maria, mas eles queriam Fernanda. Então a gente para concordar colocou Maria Fernanda.

(Mãe 4)

Ele gostava da ideia de ter um irmão. Ele queria ter um irmão. Mas ele queria um irmão homem. Eu, digamos assim, não tinha exatamente uma ideia de homem ou mulher. Mas eu, como já tinha um homem, até se tivesse que escolher eu preferia uma mulher, a experiência de ter uma mulher. Mas, ter filhos também era muito fácil, muito mais conhecido. Homem é mais prático. Menina é mais diferente. Por exemplo, eu sou muito independente, muito prática. Eu sou muito agitada. (...) Ele ( $o$ filho biológico), eu queria maior e ele queria menos idade. Eu queria mais idade. É porque ele sempre, eu acho, que ele ficava menos assustado, porque quando a gente começou a ir a orfanatos... E ele, na medida que foi crescendo, ele começou a ver meninos menores e ver que ele tinha mais facilidade de brincar. 
Ele sentia a coisa mais tranquila, quando ele lidava com meninos mais ou menos da idade dele.

(Mãe 6)

(Respondendo sobre a reação da filha à notícia da adoção de outros filhos.)

Super, hiper bem!!! Pelo contrário, nós duas saímos, compramos juntas. Ela que escolhia tudo para o quarto deles. Então, ela se sentia a responsável. Me lembro que a gente tava... (...) Nós saímos juntas, escolhemos os lençóis, escolhemos isso, aquilo outro. (...) Ela é de outro planeta de boa. Ela recebeu superbem.

(Mãe 7)

Aí, quando eu tava mais ou menos já estabilizada e tal, aí eu falei: “Ah, vou ter outro filho". Mas, aí logo depois eu me separei. Aí eu falei: "Ah, não vou fazer uma produção independente, porque assim um filho de qualquer um". Aí minha filha, na época era uma adolescente de 12 ou 13 anos, falou: "Ah, vamos adotar, vamos adotar". (...) E ela sempre me cobrava: "Ah, vai lá”.

Como já dito, a não aceitação do filho adotivo por parte dos grupos sociais é sentida pelos pais como uma agressão, uma rejeição, porque os atinge na sua cadeia genealógica. A escola apareceu como uma instituição importante, que compõe a rede de apoio para esses pais. Contudo, eles reclamaram do despreparo das escolas para tratar, por exemplo, de um tema específico da adoção: a rejeição, especialmente o bullying. Em consonância com Klein (1923), que afirmou ser a escola um encontro com a realidade na vida da criança, pensamos que, para os próprios pais, a escola é também o encontro com uma parcela da sociedade. Talvez seja essa uma das razões de ser um encontro significativo para esses pais. Ao mesmo tempo pudemos identificar, a partir dos relatos, que a escola, justamente por sua importância, também se tornava um contexto de grandes desencontros, como ilustram os trechos a seguir.

(Pai 2)

E ela teve problema no colégio nessa época também, tava com a mãe doente, mal. Aí teve, como se chama? Bullying, eu tive que tirar ela do colégio, então foi uma série de perdas...

(Mãe 2)

E eu passei a conviver com outras pessoas também que já tinham adotado, e que estavam em processo de adoção. Inclusive da minha família, pessoas que fizeram adoção. É... se possível gostariam de esquecer que aconteceu uma adoção: "Vamos imaginar que são filhos biológicos, os demais não precisam saber de 
nada", porque na própria escola tem comentários, porque os outros olhares com quem convive, onde mora, as pessoas olham de uma forma diferente, a própria criança mesmo...

(Mãe 8)

Nem toda escola está preparada para lidar com as pequenas questões da... da... de uma criança adotada. Não que sejam diferentes, não. Mas, são certas questões, por exemplo, quando ele tinha 6 anos e saiu da escolinha dele, da creche pequenininho, que todo mundo sabia da situação dele. E que tinha outras crianças adotadas e isso tudo era falado com muita, muita liberdade. Ele foi para uma escola maior, assim que ele chegou eu falei na diretoria que ele era adotado porque poderiam surgir questões que talvez ela não soubesse lidar e tudo mais. Logo no início eles faziam assim, pegavam um livrinho, na semana, e liam, debatiam aquele livro, e aí ia ser escolhido o livro que ia ser estudado durante o ano. Aí ele chegou em casa muito mais agitado do que ele era e no dia seguinte ele me trouxe um livro que leram na escola, e era um livro de como eu vim ao mundo, como eu nasci. Da concepção até o processo, contava todo o nascimento. Aí eu percebi, a historia que ele chegou não é só essa, aí eu fui na escola, entreguei um livro para ela, que conta a história de uma criança chegando na adoção. (...) Então o livro foi lido e ele no meio de 30 crianças novas, com 6 anos, ele levantou e falou: "Essa é a minha história".

Além da família extensa e da escola, percebemos que os profissionais de saúde, principalmente os psicólogos, têm uma acentuada presença na vida das famílias estudadas. Todos os entrevistados relataram passagem dos filhos por algum tratamento psicológico, mais por determinação dos pais do que pela vontade dos filhos. Os pais apresentaram as mais variadas justificativas para recorrerem à terapia, entre elas, melhor elaboração, por parte dos filhos, da condição da adoção, ou preocupações com os traumas. Apenas dois dos entrevistados mencionaram ter feito algum tipo de psicoterapia, mas sem nenhuma relação com a adoção.

Falamos anteriormente sobre a pesquisa de Lee Fu e Matarazzo (2001), que constataram existir a prevalência de atendimentos aos adolescentes e às crianças adotivas nos serviços de saúde mental. Conforme já descrevemos, as pesquisadoras verificaram que em determinadas famílias marcadas pela infertilidade do casal, haveria grande intolerância e ansiedade com relação à criação idealizada dos filhos adotivos, e como consequência esses pais procuravam com mais frequência os serviços de atendimento clínico.

Tomando como base as narrativas de nossos entrevistados, pudemos observar que não foram somente os casais com problemas de infertilidade que 
buscaram tratamento psicológico para os filhos. As demandas não envolviam necessariamente queixas de problemas emocionais, sendo algumas caracterizadas como uma prevenção de problemas. Pensamos que isso desmistifica a discussão sobre os sujeitos adotivos apresentarem, ou não, mais problemas emocionais do que a população em geral. O que percebemos, pelo menos a partir deste pequeno grupo de entrevistados, é que existe uma gama de fantasias, coloridas por ambiguidades e ambivalências, que são desconsideradas pelos sujeitos. Uma forma de aplacar tais experiências emocionais é buscar explicações racionais da ciência que os eximam daquilo que vivenciam. Pensamos que isso corrobora o entendimento de Forbes (2011) de que a sociedade Ocidental não suporta que sejamos órfãos de explicações, e por isso fica muito mais fácil pensar no "Freud explica", ao invés do "Freud implica".

(Pai 1)

Ele (o filho adotivo) faz análise já há uns sete, seis ou sete anos... foi a... (exmulher) receosa de qualquer problema que o levou. E ele gosta, curte, vai numa boa.

(A ex-mulher estava receosa) (...) da questão da adoção, de ter algum enguiço. Pra ele estar bem resolvido. Tem isso também, que teve essa ajuda. Mas, isso... acho que não teve nada... apenas ajudou a organizar melhor.

(Mãe 5)

Já fez já (terapia). Mas a terapeuta dele... Quando eu fiz a minha, eu não consigo comparar com mais ninguém, entendeu? Ele fez terapia com a mesma terapeuta que fez a minha sobrinha. Porque a minha sobrinha foi parar na terapia, todo mundo teve que ir. Porque teve uma escola que ele sofreu muito bullying, nesta escola.

(Mãe 4)

Faz, ele tá numa terapia desde que chegou na minha casa. Graças a Deus, a minha empresa me possibilita, que é uma coisa rara em todas as empresas, que infelizmente não são todas as empresas que têm isso. E isso é muito importante, inclusive é uma coisa que pode ser colocada até da necessidade do governo incentivar o apoio de psicólogos para crianças que estão sendo adotadas. Porque é fundamental, é fundamental. (...) ajuda muito, mais para ele perceber toda essa dificuldade, toda esse sentimento de abandono, de rejeição. Para ele se inserir, porque até mesmo, o meu filho é moreno, não chega a ser mulato, mas você vê que ele é... você vê que não é a minha cor. E ele quer, ele gostaria de ter a minha cor, ele queria estar inserido na minha família. 
(Mãe 7)

A adoção pode ser um problema, mas é muito difícil as pessoas entenderem isso. Por exemplo, o meu filho está na terapeuta. Ele faz terapia porque eu acho que a pessoa tem que cuidar da cabeça também, a gente não cuida do corpo? Tem que cuidar da cabeça. Então meus filhos, todos eles fizeram terapia. Ele fazia arteterapia quando pequenininho.

(Mãe 8)

Eu acho que ele sentiu pra caramba (a separação dos pais adotivos). Ele tinha 7 anos. Na época, o avô tinha recém-morrido. O meu ex-marido saiu dois meses depois. Então foi muito assim em cima. E já saiu com uma outra pessoa, foi um... Foi traumático, acredito que sim, mas o (filho) não menciona. O que eu pude fazer por ele foi insistir para que ele fizesse terapia. E isso eu consegui, que ele fizesse até os 13 anos.

O medo de haver algum problema com a saúde psíquica dos filhos e de eles sofrerem preconceitos talvez esteja relacionado a fantasias ambivalentes em relação à adoção. Levinzon (2000) aponta para a presença de "fantasias de roubo", gerando ansiedades persecutórias e sensações de perigo com relação ao amor do filho. Segundo a autora, existe um pavor, por parte dos pais adotivos, de que o filho possa um dia preferir os pais biológicos e, assim, abandoná-los. Em muitos casos, esse pavor é a razão de eles temerem falar sobre a origem do filho adotivo.

A partir das entrevistas, pensamos que essas ansiedades persecutórias sejam projetadas na saúde mental dos filhos adotivos, incitando o pedido de ajuda profissional para livrá-los dos "perigos" e para responder às incógnitas, com as quais terão que conviver pelo resto de suas vidas.

\subsubsection{Parentalidade na adolescência}

Em relação à adolescência, todos os pais revelaram não haver nenhuma insatisfação ou problema com a passagem dos filhos por essa fase. A partir dos relatos, percebemos que não há uma queixa explícita a respeito da "crise da adolescência" (BENGHOZI, 2010), ponto sobre o qual discorremos na fundamentação teórica. Isso corrobora os dados da pesquisa de Cerveny e Berthoud (2010) com famílias adolescentes, ao constatarem que essas famílias apresentavam-se em melhores condições do que é divulgado no imaginário, já que não procuraram tratamentos por problemas mais complexos. Perguntamo-nos se 
realmente seriam melhores condições ou se há uma negação devido à angustiante busca de identidade e ao ressurgimento de questões primitivas irresolutas.

Notamos que os entrevistados se mostraram pouco interessados em descrever como estava sendo vivida essa fase dos filhos, tendo, a maioria deles, dado muito mais ênfase à tranquilidade e à normalidade dos filhos. As dificuldades e algumas mudanças nos filhos apareceram explicitamente um tempo depois da pergunta disparadora. Apenas três mães explicitaram, logo de início, o reconhecimento das diferenças entre a infância e a adolescência, incluindo as dificuldades desta última. Seguem alguns trechos para ilustrar nossa análise.

(Pai 1)

Eu até brinco com as pessoas: "Ah, você tá com filho, 13 anos, 14 anos, 15 anos? Ih, essa fase pré-adolescência é muito ruim." "Não, nada disso, ele (filho adotivo) não dá trabalho nenhum; aliás, quem dá trabalho pra ele sou eu" (rindo). Ele é que se preocupa comigo. Lá em casa, eu que apronto e ele que toma conta de mim. É brincadeira...

(Mãe 1)

E agora na adolescência é igual a qualquer adolescente. É boca suja de vez em quando. Dá umas respostas atravessadas. Aí você tem que dar uma bronca e falar: "Por que você tá falando assim?". Dá umas broncas.

(Mãe 2)

Olha, no todo, ela é uma adolescente como qualquer outro, com aqueles conflitos existenciais normais, com aquela coisa assim, com as inconstâncias de emoções, né? Uma hora tá muito alegre, outra hora tá muito emburrada, entendeu?

(Mãe 3)

Bom, uma criança tranquila, fez terapia, fez tudo numa boa. Quando chegou na adolescência... aí, ele começou a ficar muito rebelde. Parou de estudar, foi um horror. Eu trabalho com adolescente, e começou a ficar com 11 anos. Eu, quando adolescente, acho que fiz muito mais coisa do que ele, mas... a cobrança era diferente.

(Mãe 4)

É tenho dois na aborrecência. (...) Eu diria que... (a experiência de ser mãe nesta fase) (...) algumas vezes irritantes, outras é um pouco mais tranquilo. Talvez porque eu tenha um lado adolescente. Não, não sei. Mas, depende! Tem horas que é muito chato, muito chato, mas tem horas que é, digamos assim, razoável, dentro do possível é razoável. 
(Mãe 6)

Como ser mãe não adotiva nessa fase da adolescência! Eu acho que os meus filhos têm uma adolescência muito tranquila, muito fácil. A gente adotou ( $o$ filho mais velho, da adoção de irmãos) um pré-adolescente. Nos já colocamos ele em várias atividades, porque a gente acha que cabeça vazia, e tempo ocioso, não é bom na adolescência.

(Mãe 7)

É difícil, né? Adolescência é um pouco complicado. (...) Meu filho está na préadolescência. E começando a entrar na adolescência, e aquelas questões mesmo de já estar saindo... a gente vai ficando para trás. O que prevalece são os amigos, o social. Antigamente, mãe sabe tudo, mamãe é... Agora, mamãe já não sabe nada, a palavra do amigo é mais forte. Mas, assim... Nada que seja diferente, porque é um momento meio complicado mesmo.

Como já vimos, Anna Freud (1976) escreve que, diante da ansiedade provocada pelo apego aos objetos infantis, os adolescentes recorrem ao deslocamento da libido investida em tais objetos. No último trecho da fala da Mãe 7, podemos encontrar a manifestação deste movimento no adolescente. Provavelmente, existe uma dor, um luto necessário de ser vivido pelos pais, em razão da perda da imagem de serem objetos idealizados para os filhos. Acreditamos que mesmo aqueles que não explicitaram este luto, ao valorizarem a proximidade com os filhos e a abertura de diálogo, falam da valorização de serem pessoas importantes e de influência na vida dos filhos.

Benghozi (1999) compreende metaforicamente as transformações psíquicas do adolescente como uma mudança de "pele". Acreditamos que a anamorfose, proposta por esse autor para os adolescentes, também pode ser aplicada aos pais, já que eles lidam com as mudanças da própria imagem pela perspectiva dos filhos. Ou seja, devem se confrontar com a mudança do lugar que ocupam na mente dos filhos.

(Pai 1)

(...) Então, eu não procuro prendê-lo muito, mas conversar muito sobre como é que é a vida. Discutir lógica, estratégica, essas coisas todas... comportamento. Mas sem ficar... tentar influenciar o comportamento, o que quer que seja. Bom, fora de situações, e como resolver. De modo que ele não deu trabalho nenhum. A gente é companheiro, do tipo eu ensino ele a beber. Então, vamos beber. 
(Pai 2)

Teu filho na adolescência te acha o cara mais burro do mundo. Aí, quando ele está saindo da adolescência, ele pensa: "Como meu pai aprendeu rápido!" (brincando/piada). Eu tenho essa frase comigo. E têm uns três anos de "meu pai não sabe nada", o grupo é quem sabe. É aquela coisa de adolescência de questionar tudo.

(Mãe 3)

Ele não mente. Lógico que, quando mais novo, ele mentia, mas era com besteira. A gente tem uma cumplicidade de tipo assim: onde ele estiver, ele fala. Ele liga para eu saber, ele deixa o celular ligado. A gente conseguiu uma parceria muito boa em relação a isso.

(Mãe 5)

A gente foi superprotetor sim, com certeza. Isso talvez tenha prejudicado ele. Nessa hora, que ele fica preocupado com a gente também, porque a gente é assim. Mas ele já fez viagem da escola, com o pessoal, com as professoras, entendeu? Mas ele tem a preocupação, que ele sabe que nós somos meio babões com ele. A gente agora solta, tanto que ele vai para o shopping com os amigos. Aí, ele tenta dar uma rasteira: "Ah, os meninos vão subir juntos! Da praça vão todos subir juntos” Mas não sobem. A gente olha pela janela e ele tá vindo sozinho. E ele, às vezes, quer se livrar um pouco da gente. E agente está grudado nele, porque a gente adora grudar nele.

Dentro do que foi exposto nesses trechos, chama a atenção a reafirmação de que os filhos não dão trabalho algum. Parece que existe uma exigência de que sejam filhos adequados, perfeitos. Supomos que, num nível inconsciente, essa percepção do filho perfeito seja necessária aos pais como uma forma de reasseguramento de que tudo deu certo e de que foram bons pais, apesar das "mazelas".

Winnicott (2005) afirma que o movimento do adolescente caracteriza-se por duas tendências. A primeira corresponde a que o jovem se afaste da mãe, do pai e da família, adquirindo maior liberdade de pensamento e de ação a cada passo. A outra tendência dirige-se ao sentido oposto e equivale à necessidade de o adolescente conservar o relacionamento com a família, como reflexo de recaídas na dependência.

Observamos que uma dificuldade encontrada pela maioria dos pais é a necessidade de impor limites aos filhos. Vimos que sem limite coloca-se em cena a tragédia familiar, pois tanto o interdito quanto o reconhecimento do semelhante 
encarnam o limite, determinando ordem aos grupos humanos. Talvez este seja um sentido inconsciente para tanta preocupação com os limites, uma vez que são os limites que permitem os interditos, impedindo a realização dos desejos edípicos. Talvez também existam dúvidas dos pais com relação a seus próprios limites, até onde podem intervir na vida dos filhos, de modo que a constituição da autonomia e da diferenciação dos filhos não seja prejudicada.

(Mãe 1)

Onde vai, boto hora pra chegar. Falam: "Mas ele tem 17 anos, deixa ele". Não é que eu sou preocupada, não, eu não sou aquela mãe que fica: "Ai meu Deus, será que vai acontecer alguma coisa?" Não, não sou. Mas eu acho tão importante essa coisa, sabe? Talvez, porque eu não tenha tido. Eu falo: "Eu faço isso porque eu me preocupo com você. Se eu não me preocupasse, eu não tava ligando pra que hora você vai chegar, com quem você vai"... Eu acho que não é uma coisa de controlar. É uma coisa de eu sei onde você está e com quem você está. Embora, uma coisa é claro, eu acho que com as meninas tinha horas que eu não sabia com quem estavam. É claro isso, mas elas têm a sensação, e agora o Pedro, de que eu quero saber onde estão, com quem estão e o que estão fazendo.

(Mãe 7)

Se eu for me comparar com as outras mães, eu não tive muito problema com ela e não tenho com ele, mas com ele eu tô começando ainda. Mas eu acho que é aquele problema de afirmação. Por exemplo, ele está começando a andar sozinho. Então, ele, estamos fazendo testes. Então, ele já quer mais, sempre mais do que é permitido. Eu acho que nunca tem um ponto final. Eles sempre querem mais e mais. Se você deixa andar duas quadras, querem três, é o negócio da insatisfação que tem dentro deles, a questão do limite.

(Mãe 8)

Por exemplo, mudou, eu vejo a mudança nele, né?! A mudança de visão, de comportamento. Eu vejo que ele está por um lado muito bom da vida. Ele tem questionamentos, ele tem posições que concordam comigo. Agora, ele grita, ele briga, ele me agride, ele transgride, como qualquer outra criança. A única coisa que me assustou muito, porque eu venho de uma família que conseguiu neutralizar todas as transgressões de todos de lá de casa. E eu via que a gente não transgredia nada, a gente era muito obediente. Ele já não, ele é uma pessoa que gosta de impor a vontade dele, e eu tenho que segurar a rédea. Mas ele é uma criança que ouve. Ele é um adolescente que tem posicionamentos certos. Eu vejo que ele está amadurecendo, ele está indo. Agora, transgride.

Desses limites, então, é uma coisa que ele precisa e que nesse momento eu preciso cortar a transgressão. (...) Em relação a sexo, a gente conversa muito, ele tá com uma namorada de um ano, a gente já sabe. 
Entre as principais preocupações dos entrevistados, predominaram o uso da internet, de drogas e a iniciação sexual. Essa manifesta predisposição dos pais para conversar sobre sexo é um dado contrário ao resultado encontrado na pesquisa de Cerveny e Berthoud (2010), onde o assunto foi visto como um dos três mais evitados nas famílias. Com relação à internet, a queixa basicamente era da frequência dos filhos a sites que consideravam inapropriados. Para lidarem com a questão das drogas e da iniciação sexual, os pais procuravam manter uma conversa aberta com os filhos. Os pais destacaram sentir orgulho de serem pais que conseguiam conversar sobre estes temas, sem restrições aparentes.

Pensamos que estas questões pertencem, igualmente, ao campo do limite, da castração. Fizemos referência ao mito da "horda primeva", governada por um pai onipotente, portanto, sem limites. Por meio do assassinato e o canibalismo do pai onipotente, os filhos primitivos efetivaram concretamente a internalização do pai. Assim, passamos a compreender, respaldados em Freud, a importância da internalização do pai, da lei, o que, no desenvolvimento psíquico, significa uma conquista para adquirir a capacidade de simbolização e a castração (BRUNNER, 2000).

Os adolescentes perturbam e exigem dos pais à lei, para poder internalizá-la, eles representam a transição entre um estado de intensa expressão pulsional para uma adaptação à interação social . As narrativas ilustram como, na interação entre pais e filhos adolescentes, a obediência é imposta de fora pelos pais para viabilizar uma forma de obediência baseada na internalização das regras, e assim reatualizar a consolidação do simbólico, da cultura.

No tocante às expectativas de futuro, nove dos dez entrevistados mencionaram o desejo de ver a felicidade dos filhos, demonstrando preocupação quanto ao futuro profissional dos mesmos. Este apreço pelo futuro profissional vai ao encontro dos resultados da pesquisa de Cerveny e Berthoud (2010), que entenderam a valorização dos estudos como um dos principais valores da classe média brasileira.

(Pai 2)

Eu procuro não ter muita expectativa, porque quanto mais a gente engessa o caminho, mais a gente tolhe as oportunidades, às vezes até melhores. Às vezes você pensa que vai ser melhor pra você e não vai. Há três dias, a gente terminou 
lá o processo de orientação profissional, vocacional, essa coisa toda. Umas seis, sete sessões. E nós fomos ver o resultado.

Eu tenho ótimas expectativas pra eles. O que eu falo pra eles é: "Vocês têm que trabalhar com o que gostam, senão tiver que trabalhar aqui na empresa... Eu não quero determiná-los a trabalhar aqui”.

(Mãe 6)

Eu sou a mulher das expectativas! Ah, eu... Eu vou te dizer qual é a minha grande preocupação. Eu, graças a Deus, não tenho preocupação em termos de drogas, ou álcool. Primeiro, por estar muito atenta e por ter falado muito sobre isso.

\subsubsection{O “insondável”}

Poderíamos dizer que esta se revelou a categoria mais imprevisível da tese, pois foi construída a partir de um dado inicialmente intrigante, revelado no discurso de todos os entrevistados. Esse dado, surpreendente tanto pela manifestação propriamente dita quanto pela frequência que surgiu nas narrativas, corresponde à narrativa de alguma situação de morte/perda. Após a percepção de que tal dado constava de todas as entrevistas, o enigma estava instalado. Qual era o significado dessa unanimidade?

Nós, que consideramos a influência do inconsciente, não nos contentávamos em pensar simplesmente que a morte faz parte da vida e por isso era mencionada. Da mesma forma que um elemento da associação livre desperta a atenção flutuante do analista, a morte/perda nos provocava uma interrogação inquietante. Este dado foi deixado em suspenso, enquanto as demais categorias foram sendo desenvolvidas. Contudo, a pergunta permanecia: o que a revelação de mortes nas narrativas poderia nos dizer no nível latente? Lembremo-nos mais uma vez da pesquisa de Cerveny e Berthoud (2010), na qual, em relação às práticas das famílias, elas constataram os três assuntos mais evitados nas conversas, e o primeiro deles é morte (40\%), depois doenças (31\%) e sexo (16\%). Ou seja, em mais uma pesquisa a morte/ o luto se apresentou como uma questão. 
(Pai 1)

A separação nossa foi uma coisa muito mais da Diana do que comigo. Ela entrou num processo de sofrimento psíquico, em função de muito trabalho e algumas coisas da família dela. Inclusive a notícia da morte do pai. Ela teve uma crise e jogou tudo pra mim evidentemente (rindo). Me ligou, e disse pra gente se separar: "Não, porque eu vou pra casa do papai. Já arranjei advogado".

(Pai 2)

(Ficou viúvo precocemente, contando o fato no início da entrevista. Também mencionou a morte precoce do pai, ao falar de sua adolescência.)

A minha mãe era viúva. Quando ela ficou viúva, ela voltou para a casa do pai. Aí, nós fomos morar junto com eles. Eu tinha 10 meses quando meu pai morreu. Eu fui criado numa família... Não tenho problemas de fillho único, na medida em que eu fui criado numa família com primas na mesma casa, que era grande. Então, tinha minha mãe, tinha minha madrinha, morando na mesma casa, e minha madrinha têm três filhas. Então, eu tenho três irmãs, sou filho único que teve três irmãs. (...) Mas a figura masculina eu perdi, porque perdi o pai. Mas tive essa figura masculina (avô), que de certa forma cobriu.

(Mãe 2)

E eu sempre tive um bom relacionamento com a minha mãe, e eu sempre tive uma grande preocupação com ela no sentido assim, principalmente, quando o meu padrasto morreu, que eu considerava o meu pai, meu padrasto, né?! E minha mãe entrou num desespero muito grande com a perda dele. Eu me vi assim, eu agora preciso ser o apoio dela. E aí aquele tratamento possessivo que ela já tinha em relação a mim se tornou maior, porque eu, sem querer, inverti os papéis. Eu, na tentativa de suprir as carências da minha mãe, eu acabei assumindo pra mim coisas que eu não deveria ter assumido.

(Mãe 3)

Agora, ele (o filho adotivo) tem um problema de perda muito grande. Ele tem um medo louco do pai morrer. O pai é mais velho do que eu, e ele morre de medo do pai morrer. E isso não está legal, tanto não está legal que eu já falei para ele fazer terapia, e ele não aceita.

Tipo assim: eu, com 11 anos, perdi um irmão, ele tinha 19 anos. Eu tinha uma irmã com 7 anos, tenho uma irmã quatro anos abaixo e um irmão quatro anos mais velho. Éramos quatro, ficamos três. Minha mãe pirou. Em um mês o cabelo da minha mãe ficou todo branco, não me pergunta como, tá?! Eu tinha 11 anos e tive que assumir a casa. Eu arrumava a casa, eu fazia almoço, eu colocava o meu irmão mais velho na escola, a minha irmã mais nova para a escola, eu tinha que ir para a escola. A minha mãe, ela parou de viver. 
(Mãe 5)

Entrevistadora - Você saiu de casa nessa época?

Mãe - Não. Eu fiquei noiva, só que ele morreu. Isso foi em 1965. Não tinha as coisas que tem hoje, celular, nada disso. Ele ( o noivo) não sabia que ele tinha passado direto, ou se ele tinha mais prova, porque ele ia passar para oficial. Aí ele foi para ter certeza se ele tinha passado, ele tinha que ir lá para saber, na Cidade X. Só que o ônibus caiu em um rio e ele morreu. Morreram todos! Só salvou-se um que estava em cima de uma pedra, e não sei te dizer como. Tinham 40 pessoas e morreram todos. Foi terrível.

(Mãe 4)

Mencionou os abortos que fez e a perda de um bebê, relato apresentado na primeira categoria.

(Mãe 6)

Falou sobre a doença do filho, o medo implícito de ele morrer, e sobre a perda dos bebês, falas já explicitadas em categorias anteriores.

(Mãe 7)

E têm famílias que ficam seis, sete anos com a criança e aí na adolescência o bicho pega e aí vai devolver: “Ah, essa criança é insuportável!” Mas, vem cá: não teve o vínculo durante os dez anos? Às vezes eu fico pensando assim: "Pô, como é que uma pessoa vive? Se gosta de um cachorro que vive com você há dez anos". O meu cachorro morreu, eu quase morri junto. Então, como você passa dez anos com a criança? E tudo bem, mesmo que você não tenha conseguido amar aquela criança como filho, que já acho difícil na minha cabeça.

(Mãe 8)

Falou da morte do pai aos 18 anos e da perda de um bebê, relato já comentado em categorias anteriores.

A hipótese que criamos levou em consideração os dados discutidos nas categorias anteriores. Tal como observamos, o mito de origem, pungente nessas famílias, era questionado nas mais diversas etapas de desenvolvimento. Pontuamos que perdas e lutos perturbadores, em associação ao mito de origem, dão um colorido específico às vivências naturais do desenvolvimento. Entre os lutos mencionados pelos entrevistados, mas não reconhecidos explicitamente como uma perda, observamos o luto pela não semelhança física com os pais, ou o luto pelo fato de o filho adotivo ser "do coração" e não "da barriga". Tais elementos, dentre outros, nos fizeram crer que a revelação dessas situações de 
mortes reais foi um caminho inconsciente para que a perda, constitutiva do vínculo adotivo, fosse falada.

Verificamos que, para haver a parentalidade e a filiação adotivas, algo necessariamente teve que ser perdido. Essa perda é o que viabiliza a construção de novos elos de parentesco. Portanto, acreditamos que, ao falarem de mortes, os entrevistados explicitam o ponto nodal (a perda, o insondável) que possibilitou o vínculo parento-filial adotivo. Eles recusam este elemento, mas, quando mencionam outros buracos/perdas não associados à adoção, consequentemente eles revelam sua existência. O curioso é que esse mecanismo defensivo, ao mesmo tempo em que burla a realidade do senso de morte/perda, também tenta dar conta do mesmo.

Seria pertinente a indagação sobre as razões de tamanha recusa como atitude defensiva. Buscamos entendimento, para esta indagação, nos apoiando nas formulações de Ferry (2010) sobre o significado da morte para a existência humana. Como já ressaltamos, este filósofo aponta que distintamente dos outros animais, o homem se singulariza pela consciência de sua finitude, compreendendo que irá morrer, bem como seus semelhantes. A interrogação sobre a finitude permanece latejante, justamente pelo caráter insensato e insuportável de viver sem objetos amorosos ou perder a própria vida.

Vimos que o autor nos faz um alerta importante ao pontuar que a frustração com relação à realidade da própria morte vai muito além da simples constatação do "fim da vida", sugerindo que o tormento maior da morte é fazer o homem ter que conviver com o irreparável e ter seguir em frente. Assim, se fundamenta a angústia primordial humana, pelo temor ao contato com o irreversível, à convivência com o que "nunca mais poderemos reencontrar.

O ser humano, portanto, traça o projeto de procurar uma morada pertencente à ordem do "para sempre". Sendo assim, respaldamos nosso entendimento sobre as mortes mencionadas pelos entrevistados, nessas postulações de Ferry (2010), como já explanamos, e de Freud (1919) com a ideia do terror ao nunca mais, no texto $O$ estranho, a partir da noção do duplo. Destacamos que o desejo de ter um filho pode ser entendido como o fenômeno do duplo, o desejo de duplicar-se ao transmitir o nome, o seu narcisismo, aplacando o buraco da morte.

Compreendemos que inconscientemente o "buraquinho" mencionado por alguns pais e as mortes mencionadas por todos, talvez representem o que estes 
autores falam da angústia primordial em ter que lidar com o "nunca mais", simbolizando o insondável no ego, a castração. As conceituações de Money-Kyrle (1978) a respeito dos três obstáculos emocionais, que precisam ser ultrapassados para constituir um aparelho psíquico pensante, também, colaboram para nossa compreensão: o reconhecimento da dependência que a vida tem da generosidade dos objetos; o reconhecimento natural da exclusão na relação sexual parental, portanto, da capacidade criativa dos pais de se juntarem e conceberem uma criança; e por fim, o reconhecimento da inevitabilidade da morte, que é imposta ao ser humano contra a sua vontade. Lembremos-nos que o autor salienta que todos os posteriores atos de reconhecimento dependerão de como foram vividos esses primeiros e de que dificuldades foram registradas primitivamente. Ele ressalta que todos os sujeitos viveram dificuldades de algum nível nesses obstáculos.

Como discorremos no capítulo quatro, Money-Kyrle (1978) pontua que uma das dificuldades de reconhecer que a vida depende dos objetos está relacionada à dura impossibilidade de usufruí-los para sempre. "A capacidade para lamentar, ou para sofrer a perda, e a capacidade de lembrar o objeto perdido estão inseparavelmente ligadas. Sem a memória não pode haver luto e sem o luto não pode haver memória" (p. 457). Somente com o registro da existência do objeto e de sua perda, promotora de uma falta, é que será possível a organização de um ego criativo, produtor de pensamentos, de construções e de reconstruções.

Acrescentamos a este debate as formulações de Filho (2009) ao mencionar que o conhecimento parcial sobre a pré-história da criança é um dos buracos narcísicos nos pais. Este "não saber" sobre a história do filho remete os pais adotivos à parte desconhecida de sua própria história, uma vez que, em qualquer história, todo sujeito está excluído de sua própria criação. Entendemos que o autor coloca em questão as fantasias dos pais relacionadas ao insondável de sua própria história, ao reconhecimento da exclusão do casal parental criativo e a como estas fantasias os influenciam ao lidar com que há de insondável na história dos filhos. "Para algumas pessoas os incômodos provocados pela adoção estão mais voltados para o que é desconhecido do que para o que venham a conhecer durante a criação" (FILHO, 2009, p. 24).

Propomos ampliar esta ideia do insondável/ "buraquinho", ressaltando que essas famílias vivem na pele o "nunca mais" na formação da parentalidade e da 
filiação. A vinculação só foi possível porque houve uma descontinuidade, um "nunca mais". Como descrito por Kernberg (1985), a criança adotiva possui duas incógnitas em sua vida. A primeira diz respeito ao desconhecimento de quem foram seus pais biológicos. A segunda corresponde às razões da descontinuidade da convivência. Há, nessas crianças, a ferida muito precoce da consciência de que não há nada que eternize os vínculos de parentesco.

$\mathrm{Na}$ cabeça dos pais talvez o biológico ganhe peso, pois na fantasia remeteria ao "para sempre", ao duplo, à ideia de que a transmissão genética ninguém pode tirar. Mas, para as crianças, o biológico não foi suficiente para serem "adotadas" por seus genitores. Na história da família adotiva, a condição humana "do nunca mais" torna-se uma ferida à mostra, e possivelmente trazendo maior vulnerabilidade aos vínculos, como uma fratura exposta que fica mais suscetível a infecções. Veremos que alguns dos entrevistados reconhecem a fratura. A Mãe 1 fala em "buraquinho", talvez usando o diminutivo defensivamente, para aplacar o real tamanho do que existe de insondável.

(Mãe 1)

Mas eu acho que pelo fato de não fazer diferença para a gente, o fato de ele ser adotado, talvez isso não faça tanta diferença para ele. Porque ele tem aquela coisa assim da criança adotada, que tudo que eu li na vida sobre adoção, ou que eu conversei com as pessoas, que diz que o adotado tem um buraquinho que você não preenche. Então, não adianta o que você fizer de material ou emocional... (interrupção) Eu acho que ele é tipicamente atípico dos adotados que eu conheci. Mas ele tem esse buraquinho.

(Mãe 4)

Por exemplo, eu faço um trabalho, eu elogio muito o tempo todo. E não é só para agradar, não! Eu falo de verdade! Hoje mesmo no café da manhã eu olho para ele, ele não gosta: "Tá olhando o quê, mãe"? "Eu olho para você. Fazer o quê? Você é lindo!" "Para, mãe, não gosto!" (...) "Sabia que eu te amo?" (ela fala para o filho adotivo). "Ah, eu já sei. Para de falar isso!" (o filho lhe diz). "Não sabe não." "Ai, você fica falando, já enjoou!". "Mas tem que falar para você não esquecer que eu te amo, te amo, e você não pode esquecer". Mas, ao mesmo tempo ele tem aquela coisa do adolescente, de "Para, que saco". Mas, no fundo, precisa ouvir, precisa saber que é amado, que é querido, porque não tem essa... E tem coisas que você não pode resgatar, porque elas vêm da infância. E tem coisa da infância que não dá para resgatar, e como eu vou fazer? Como você vai fazer para dar uma atenção para uma criança que não teve, na hora que mais necessitava, que não teve toque, que não teve isso ou aquilo? 
(Pai 2)

(Referente ao insondável)

E tem esse problema da adoção, né. Eu sinto que existe um não compreender. Ela tá... ela fala pouco sobre isso, embora ela saiba de tudo, né. Ela não fala, ela evita.

(Mãe 8)

Eu pensei assim: ele já teve uma perda na infância, no nascimento, porque por mais que eu supere o amor da mãe biológica dele, ele tem uma perda. E essa perda, esse vazio vai ser para a vida dele toda. Eu tenho que... dar meios a ele, força para sair desse vazio. Aí eu pensei: "Meu Deus do céu. O menino já teve essa perda, por mais pais que nós estamos ali, a perda é dele, da mãe biológica". Depois teve a perda do avô, que ele gostava muito e sai o pai de casa... "Ele não vai aguentar!" Aí eu insisti muito e ele foi (para a terapia), foi por aí que eu pensei isso.

Tomando as reflexões e os trechos destacados, podemos afirmar que feridas e questões insondáveis todos os sujeitos possuem e terão que lidar com eles, desde a própria finitude à finitude dos objetos amorosos. O que vemos de especificidade na adoção é uma intenção inconsciente de querer burlar este senso de morte, de "nunca mais". Entendemos que esse aplacamento rígido da perda, do "nunca mais", inerente à trama adotiva, promove uma abertura para uma vulnerabilidade psíquica nas relações familiares, na medida em que a perda, ao não ser reconhecida, não leva ao luto e à legitimação da nova história. 


\section{CONSIDERAÇÕES FINAIS}

\section{O Vitral}

“- Eu sei. E já sabia há muito tempo. Um dia aconteceria.

Nada mais pode ser feito.

A casa será vendida, pois seus habitantes primeiros morreram, e ela tornou-se grande para os dois.

Admito até que seja demolida. Seria até preferível.

Não gostaria de voltar a vê-la sem os nossos rostos nos retângulos das janelas.

Não! Não pensem que vou chorar agora ou quando se fechar esta porta de jacarandá maciço para que outros a abram e vivam uma outra história.

Não olharei para trás, podem estar certos, com a paixão da curiosidade transformadora de mulheres em estátuas de sal.

Tudo será deixado, exceto o vitral.

Ele irá comigo... e continuará.

Não importam os seus quatro metros de altura e dois de largura.

Já sei! Vejo nos seus olhos: E o peso? O transporte?

Por favor, olhem-me bem nos olhos! Não, não tenham medo!

Aproximem-se mais... mais. Assim. E agora me digam sinceramente, eu não tive pesos maiores?

Por acaso tenho sido fraca carregando os fatos?

Levo o vitral comigo porque com ele aprendi a sonhar.

Sonhei em amarelo, roxo, verde, azul através dele - através.

Meus risos eram refletidos nele. Ah! E confesso agora, algumas lágrimas desceram pelo seu contorno transformando suas cores em emoções.

Quero que entendam. Não é um capricho. É um direito. $O$ direito de não abandonar os meus sonhos. Todos nós temos o nosso momento de irrefutável querer.

É um querer vindo não se sabe bem de onde. Talvez... Talvez do todo que sempre fica no pouco de alguma coisa.

Acredito que agora compreendam e possam ajudar-me a colocá-lo em outra parede... em outro começo... por muito tempo".

(Conto de Gilberto Machado, pai da autora) 
A palavra conto deriva do termo latino compŭtus e significa contar (site Conceito de, 2013). Esse conceito faz referência a uma narrativa curta, que vai direto ao ponto. Por isso, tudo importa - cada substantivo, cada pontuação, cada espaço, cada descrição, -, configurando-se em pistas e valiosos sentidos. Assim, tudo possui significados insubstituíveis. Acreditamos que seja dessa forma que devemos entender a situação das famílias adotivas. Para elas, cada história, cada fantasia, cada afeto, tem um significado único, contando um ponto de seu conto. $\mathrm{O}$ que pretendíamos com esta tese era olhar bem nos olhos da trama adotiva, não ter medo de encarar os fatos e discorrer sinceramente sobre os pesos que habitam o inconsciente. Somente assim não tornaríamos fracos aqueles que carregam este vitral.

Neste vitral adotivo, nenhum pedaço de vidro colorido deve ser suprimido. Diferentemente do que vimos na maioria dos discursos dos entrevistados, principalmente em relação às ambiguidades da filiação e à ambivalência da parentalidade. Lembremo-nos das situações nas quais as mães disseram, a partir de seus atos falhos, que não sabiam como falar com o filho que ele não era seu filho. Como na situação relatada pelo Pai 1, ao contar o pedido do filho de ter um irmão, na qual a mãe adotiva não pôde pensar sob a lógica do filho, de que ela poderia adotar novamente, para lhe dar um irmão. Ou como na situação da Mãe 6, que, ao ver o desenho do filho elaborando a realidade anteriormente contada por ela mesma, nega que a bola oval não seja sua barriga.

Pudemos perceber que aplacar as contradições afetivas tem como resultado emocional a constituição de uma filiação ambígua e a dificuldade de legitimar a parentalidade adotiva. Ou seja, a vivência integrada de serem pais e filhos, pertencentes à mesma cadeia genealógica. Supomos que um influente fator para esta situação seja a falta de elaboração de algum luto, alguma situação atravessada pelo "nunca mais", como foi explicitado na categoria do "Insondável".

O "nunca mais" vivido pelos filhos talvez seja mais fácil de identificar, ou até estejamos minimizando-o, como fizeram os pais ao recorrer ao diminutivo de buraco. Apenas podemos dizer que o que denominamos de insondável é constituído com os "pedaços de vidro coloridos" da privação de conviver com seus genitores e dos registros primitivos dessa relação descontinuada. Registros estes que foram negados intensamente pelos pais adotivos que entrevistamos. 
Ilustramos este argumento com a descrição da situação do medo "inexplicável" de cachorros do menino/bebê, que fora "atacado" quando deixado em um quintal.

Sendo assim, percebemos a forte desconsideração da existência de um registro das experiências primitivas do bebê. A hipótese que criamos é que, talvez para não ter que lidar com a impotência do "nada mais pode ser feito" e ter que encarar o agora só resta ter que elaborar os fatos, alguns pais provavelmente sejam como a personagem do conto e pensem que até seria preferível demolir aquilo que não deve existir. Neste caso, o que deve ser demolido na fantasia de pais e, consequentemente, na dos filhos é a dura realidade de que o mesmo objeto que deixou ir o filho biológico, seja por quaisquer razões, é o mesmo que lhe deu a vida. Existe alguém que permitiu o nascimento, mas não conseguiu manter um elo, deixando o buraco.

O "nunca mais" dos pais se mostra mais variado, difuso, deixando escapar uma pequena luz sobre fatos pouco claros para entendermos a dinâmica inconsciente. Fatos como a infertilidade, o tempo que passou, um desejo originado não se sabe de onde, os filhos perdidos e abortados. $O$ fato é que a adoção fora apresentada como uma escolha inicialmente secundária, e a partir daí já existe um luto a ser elaborado: a perda da primeira escolha. Defendemos a necessidade de se elaborar esse luto, ou lutos, porque, caso contrário, o representante do "nunca mais" terá sempre uma alta carga de energia libidinal, que impedirá o investimento em novas representações.

Vimos que nada é aleatório, tudo tem um sentido, como na construção do conto. A definição do perfil dos filhos desejados, por exemplo, é vista, pelos leigos, como um capricho dos pais, ou um ato de querelantes. Tomamos uma postura oposta, o perfil, as definições de sexo, de idade e demais características configuraram-se como fundamentais para alguns pais. Pelo que pudemos constatar, esta definição tem sua origem de significados na história de cada um deles. O perfil representa a busca de um semelhante, uma familiaridade definida pela identificação, que será fundamental para a inserção da criança na identidade parental e para a fomentação do senso de pertencimento.

Contudo, devemos ressaltar que se um pai prefere, por exemplo, adotar um bebê porque ele não terá registros anteriores, isto não é uma escolha calcada na viabilização da identificação como promotora do elo emocional, e sim, calcada em um mecanismo de defesa, cuja função é recusar a realidade. Neste caso, adotar 
sob esses pilares seria como quebrar um dos vidros do vitral. Por isso, encontramos na literatura o recorrente argumento de se trabalhar a motivação dos pais para adotar. A essa ideia, acrescentamos que o tipo de escolha do filho também deva ser pensado, não com a finalidade de se adaptarem à realidade das crianças à espera de uma nova família, e sim para que possam refletir sobre a sua própria história, seus próprios buracos, de modo que não permaneçam tão arraigados às suas aspirações. Quem sabe até, após essa elaboração, os pais se mostrem mais flexíveis em suas escolhas.

Podemos inferir, por exemplo, o peso que foi para a Mãe 2 ser mãe dela mesma e de sua própria mãe, levando-a a repudiar qualquer possibilidade de gravidez, possivelmente por não suportar ver, no desamparo inicial de seu bebê, o seu próprio desamparo de não contar com sua mãe enlutada. Ou como a Mãe 5, que escolhera um menino para não vê-lo sofrer, já que sua experiência como filha mulher era a de ser preterida e atacada.

Pontuamos, também, que a recomendação de contar a história da adoção é muito mais do que dizer a verdade, ou informar os fatos. $\mathrm{O}$ ato palavra é uma atitude que inicia o elo de parentesco, auxilia na metabolização do estar ligado pelo "coração" (o psiquismo) e não pela "barriga" (o biológico). A forma como será vivido este ato dependerá da capacidade emocional de cada sujeito para realizar a dupla tarefa de lidar com o perdido e com o ganho.

A elaboração da dupla tarefa pertence tanto aos filhos quanto aos pais. Registramos as particularidades dos destinos sublimatórios para lidar com o paradoxo do duplo pertencimento, como, por exemplo, os filhos que passaram a ser atentos aos desfavorecidos, aos grupos minoritários, ou se vincularam a pessoas com as quais guardam alguma semelhança. Outro tipo de destino foi a criação de sintomas, levando os pais a buscar porquês, cujas respostas eram esperadas, em sua maioria, dos profissionais de saúde. Fica a interrogação: tratase realmente de que porquês?

Discutimos o quanto a presença do mito de origem permeou os mais diversos momentos do desenvolvimento, como a curiosidade infantil sobre a origem, o desenvolvimento da sexualidade e algumas condutas de comportamento. Um fator que se mostrou muito produtivo foi a sensibilidade dos pais em reconhecer esse atravessamento. Como no relato da Mãe 8, que viu a angústia de seu filho ao questionar sobre as possíveis causas da Aids, ou o do Pai 
2, que estranhou a filha ter demonstrado incômodo ao falar da adoção após a entrada na adolescência.

Destacamos o quanto é trabalhosa a tarefa dos pais adotivos de identificar e dar significado às demandas dos filhos relacionadas à origem. A Mãe 4 precisava conversar com o filho sobre o fato de seu consumo de bebidas alcoólicas ser muito diferente do uso da mãe biológica. A Mãe 6 precisou inserir a filha em sua cultura, na qual ela não mais dormiria na rede, nem comeria farinha no café da manhã. Os filhos enviam-lhes a mensagem implícita: Sou diferente de vocês e conto com vocês para ser incluído, ser um semelhante. Concomitantemente, também vou lembrá-los de que sou diferente. Devido à exigência de uma fina escuta dos pais, a adoção caracteriza-se como uma maneira relacional difícil e vulnerável, já que muitas vezes os pais têm seus ouvidos obstruídos por fantasias conflituosas e por feridas narcísicas.

Com relação à rede de apoio, analisamos o quanto o apoio da família extensa não foi conscientemente determinante para a tomada de decisão de adotar. Observamos que a importância da família extensa ocupa um lugar no a posteriori à adoção. Os filhos daqueles que já eram pais tiveram uma participação significativa na inserção do recém-chegado à nova família. Contudo, o que chamou mais atenção foram as queixas dos pais em relação ao trabalho das escolas quanto às questões subjetivas dos filhos. Talvez as escolas não estejam preparadas, nem mesmo tenham recursos, para dar conta dos aspectos que transgridem o óbvio e têm raízes profundas na singularidade dos sujeitos.

Devemos pontuar que a rede de apoio, da qual essas famílias precisam, corresponde a uma rede que ofereça continência e promova o entendimento das relações, sem julgamentos ou camuflagens. Os pais buscam isso incessantemente, como expomos nas diversas passagens de pais e de filhos por profissionais de saúde e nas explicações diagnósticas desencontradas. Parece que essa busca incessante pelos profissionais de saúde acaba sendo, na verdade, uma demanda de saneamento das vicissitudes vividas pelos filhos. Mesmo que a intenção seja benigna, o que consideramos problema é o quanto esse desejo de saneamento carrega de intolerância com a existência dos registros anteriores, podendo propiciar uma dissociação da história da criança adotiva.

O período da adolescência foi um aspecto que ficou secundário na nossa investigação. No entanto, não se configurou de todo um fator irrelevante, ao 
entendê-la como o cenário onde as questões irresolutas da infância emergem com outra roupagem, mas denunciam as vicissitudes passadas. Conforme foi discutido, os pais demonstraram-se pouco descritivos sobre "a crise da adolescência" e mais assertivos em exaltar a "normalidade" dos filhos.

Dar o limite foi apontado, pela maioria dos pais, como a dificuldade principal da função parental neste período. Entendemos a questão dos limites como uma questão da infância que retorna, correlacionada ao complexo de Édipo e à necessidade do interdito, apresentados no primeiro capítulo teórico. Descrevemos que os pais precisam ocupar o lugar de portadores da lei que interdita, viabilizando ao filho vivenciar a experiência de perda da onipotência, humanizando-o, capacitando-o psiquicamente a viver em sociedade.

Procuramos, em nossa análise, articular de forma criteriosa os dados e a teoria, buscando uma compreensão aprofundada, principalmente no que se refere à dinâmica inconsciente. Pensamos que a escuta oferecida a essas famílias não pode ser rasa no que diz respeito ao jogo de cores do inconsciente, que compõe o vitral da parentalidade e da filiação adotivas. Compreendemos que ter realizado o estudo de campo nos possibilitou o aprofundamento de nossas hipóteses, já que a fala viva dos entrevistados proporcionou um vasto colorido para refletirmos, procurando ir além do sentido manifesto. Vale destacar novamente a dificuldade que enfrentamos para encontrar voluntários que se dispusessem a ser entrevistados.

Trabalhamos com o número possível, dentro do cronograma estipulado. Entretanto, é impossível quitar as imensas dúvidas sobre as idiossincrasias do vínculo familiar adotivo. Pretendemos, com a construção de nossas hipóteses, apenas fomentar a crença na necessidade de ser oferecida uma escuta sensível e atenta às mensagens daqueles envolvidos na trama familiar adotiva. Enfatizamos que nossas argumentações não devem ser tomadas como rígidas, mas sim como uma tentativa de não nos deixarmos narcotizar pela ditadura do politicamente correto, a qual a todo custo aplaca ou recusa afetos conflitantes e hostis, presentes em qualquer relação humana.

Consideramos que essa ditadura suprime a verdade dos afetos humanos, levando a uma percepção escamoteada das relações objetais e da própria identidade. Com isso, há um acirramento de ansiedades persecutórias e da 
intransigência superegoica, já que os impostos ideais de eu ficam cada vez mais irreais em comparação com a complexidade humana.

No que cabe aos pais adotivos, a partir de toda a análise das entrevistas, pensamos na probabilidade de existir o desejo de receberem a confirmação de que foram bons pais. Talvez, sob o ponto de vista deles, ao receberem essa confirmação, tenham a esperança de que todas as dúvidas e inseguranças (inconscientes) sejam afastadas. Durante a entrevista com os voluntários, a impressão era que eles viviam atravessados pelo medo de serem acusados por possíveis falhas e contradições psíquicas.

Defendemos que a situação da adoção deve ser legitimamente conduzida. A personagem do conto sai da antiga casa, para "nunca mais" viver nela, mas carregará consigo o enorme vitral. O vitral é composto por uma combinação de peças de vidro das mais variadas cores, permitindo a elaboração de um vibrante jogo de luzes. Metaforicamente, a personagem está levando consigo o pedaço de cada experiência emocional de sua vida. Ela tem consciência de que isso não é um capricho, mas sim um direito. Se pudéssemos dialogar com ela, diríamos que nem mesmo é um direito, trata-se, na verdade, de um dever carregar o vitral de sua história. Somente assim poderá elaborá-la e se apropriar de suas escolhas. Esta nossa reflexão não pode ser dita à personagem, mas pode ser dirigida aos mais variados profissionais que trabalham com esse contexto e às muitas famílias adotivas.

Defendemos que a elaboração simbólica da trama adotiva só será sedimentada, no psiquismo dos envolvidos, se houver espaço para a honestidade de suas mais variadas experiências emocionais. Como foi explicitado, é somente com o reconhecimento da existência do objeto e de sua perda que se pode realizar seu registro e, desse modo, ter memória, ter história. Sem o registro da história não há luto, e sem luto não há história nem a criação de novas paredes para se colocar o vitral. É a integração de todos os elementos da história ao vínculo parental-filial que possibilitará aos envolvidos se sentirem pertencentes à mesma cadeia genealógica e, assim, viverem verdadeiramente "em outro começo... por muito tempo". 


\section{REFERÊNCIAS BIBLIOGRÁFICAS}

ABRÃO, M. S. Construindo vínculo entre pais e filhos adotivos. São Paulo: Primavera editorial, 2011.

ACÁCIO, P. O papel dos grupos de apoio à adoção. Disponível no site www. angaad.org.br., 2008. Acesso em: 06/10/2010.

ANGAAD. Associação Nacional dos grupos de apoio à adoção. Disponível no site http://www.angaad.org.br/. Acesso em: 03/12/2011.

ANZIEU, D. O Eu-pele. 2.ed. São Paulo: Casa do Psicólogo, 1988/2000.

ARIÈS, P. História social da criança e da família. 2.ed. Rio de Janeiro: Livros Técnicos e Científicos, 1981.

BARDIN, L. L'analyse de contenu.Paris: PUF, 1977/2010.

BENGHOZI, P. Malhagem, filiação e afiliação - Psicanálise dos vínculos: Casal, família, grupo, instituição e campo social. 1. ed. São Paulo: Vetor, 2010, $260 p$.

BENGHOZI, P. Adolescence et sexualité: liens et maillage-réseau. Paris: L'Harmattan, 1999.

BITTENCOURT, A. M. L.. Tangências de Winnicott em Freud. 2004. Em: A., MELGAÇO, J., OUTEIRAL, E N., ARMONY. Winnicott - Seminários Cariocas. Rio de Janeiro: Revinter, 2008.

BRUNETTO, A. Psicanálise e educação: sobre Hefesto, Édipo e outros desamparados dos dias de hoje. Campo Grande: UFMS, 2008, 111p.

BRUNNER, J. Oedipus politicus: o paradigma freudiano das relações sociais. 2000. Em: M. S. ROTH. Freud - conflito e cultura. Rio de Janeiro: Jorge Zahar, 1998.

BYDLOWSKI, M. Je rêve um enfant: l'expérience intérieure de la maternité. Paris: Odile Jacob, 2010, 179 p.

BYDLOWSKI, M. Parenté maternelle et parenté paternelle. Revue Adolescence, 2006, v.24, n.1, 33-42.

CAMPOS, D. M. S. Psicologia da adolescência: normalidade e psicopatologia. 23.ed. Petrópolis: Vozes, 2011, 183p.

CERVENY, C.M. O.; BERTHOUD, C. M. E. Família e ciclo vital: nossa realidade em pesquisa. São Paulo: Casa do Psicólogo, 2010. 
COSTA, N. R. A. ; ROSSETTI-FERREIRA, M. C. Tornar-se pai e mãe em um processo de adoção tardia. Psicologia e Reflexão e Crítica, Porto Alegre, 2007, v. 20, n.3.

CYPEL, L. R. C. Psicanálise dos vínculos de família e casal e a subjetivação do indivíduo nos tempos atuais. Em: I. C. GOMES, M. I. FERNANDES e R. B. LEVISKY (Orgs.). Diálogos psicanalíticos sobre família e casal. São Paulo: Zagodoni, 2012, 239p.

DAVIS, M.; WALLBRIDGE, D. Limite e espaço: uma introdução à obra de D. W. Winnicott. Rio de Janeiro: Imago, 1982.

DICIONÁRIO INFORMAL. Disponível no site: www.dicionarioinformal.com.br. Acesso em: 10/11/2012.

DOLTO, F.; HAMAD, N. Destinos de crianças: adoção, famílias de acolhimento, trabalho social. 2. ed. São Paulo: Martins Fontes, 1998/2006, 167p.

DUCATTI, M. A. G. Diálogos sobre adoção. 1.ed. São Paulo: Casa do Psicólogo, 2004, 100p.

EIGUER, A. Os Vínculos intersubjetivos na família: função da identificação. Em: I. C. GOMES, M. I. FERNANDES e R. B. LEVISKY (Orgs.). Diálogos psicanalíticos sobre família e casal. São Paulo: Zagodoni, 2012, 239p.

EIGUER, A. Jamais moi sans toi. Paris: Dunod, 2008, 197p.

EMMANUELLI, M. Que sais-je? - L' adolescence. Paris: Puf, 2005.

ÉPOCA. O lado B da adoção: as dificuldades de relacionamento e os problemas que ninguém comenta - mas aparecem depois da adoção. E o que pode mudar com a lei aprovada pelo Senado. Revista lida em 20 de julho de 2009, n 583.

ERIKSON, E. Identidade, Juventude e Crise. Rio de Janeiro: Zahar, 1971.

ESTATUTO DA CRIANÇA E DO ADOLESCENTE. (Lei ${ }^{\circ}$ 8.069/1990). Conanda, $2^{\mathrm{a}} \mathrm{Ed}$.

FARIAS, F. e BARROS, R. M. M. Da curiosidade infantil ao desejo de saber: a criança e a infância. 2008. Em: Formação de profissionais e a criança-sujeito. São Paulo. v. 7. Disponível no site: www.proceedings.scielo.br. , acesso em : 30/06/2013.

FERREIRA, L. A. M. Adoção: guia prático doutrinário e processual com as alterações da Lei n.12010. São Paulo: Cortez, 2010, 200p.

FERRY, L. Aprender a viver: filosofia para os novos tempos. Rio de Janeiro: Objetiva, 2010, 239p.

FILHO, L. S. Compreendendo os pais adotivos. 2. ed. Recife: Bagaço, 2008. 
FILHO, L. S. Pedagogia da adoção: criando e educando filhos. Petrópolis: Vozes, 2009, 111p.

FORBES, J. Órfãos do explicável. Artigo publicado no Estadão, 25 de setembro, 2011. Disponível no site: http://www.projetopsicanalise.com.br, acesso em: 02/01/2013.

FREUD, S. A interpretação dos sonhos. Obras Psicológicas Completas de Sigmund Freud, 1900. Rio de Janeiro: Imago, 2006. v. IV.

FREUD, S. Romances familiares, 1909[1908]. Obras Psicológicas Completas de Sigmund Freud. Rio de Janeiro: Imago, 2006, v. IX.

FREUD, S. Totem e tabu, 1913-1914. Obras Psicológicas Completas de Sigmund Freud. Rio de Janeiro: Imago, 2006. v. XIII.

FREUD, S. Sobre o narcisismo: uma introdução, 1914. Obras Psicológicas Completas de Sigmund Freud. Rio de Janeiro: Imago, 2006. v. IX.

FREUD, S. O 'Estranho', 1919. Obras Psicológicas Completas de Sigmund Freud. Rio de Janeiro: Imago, 2006. v. XVII.

FREUD, S. Psicologia de grupo e a análise do ego, 1921. Obras Psicológicas Completas de Sigmund Freud. Rio de Janeiro: Imago, 2006. v. IX.

FREUD, S. A dissolução do complexo de Édipo, 1924. Obras Psicológicas Completas de Sigmund Freud. Rio de Janeiro: Imago, 2006. v.XIX.

FREUD, S. Novas conferências introdutórias sobre psicanálise: conferência XXXI - A dissecção da personalidade psíquica, 1933. Obras Psicológicas Completas de Sigmund Freud. Rio de Janeiro: Imago, 2006, v. XXII.

FREUD, S. Projeto para uma psicologia científica, 1895. Obras Psicológicas Completas de Sigmund Freud. Rio de Janeiro: Imago, 2006, v. I.

GAGNO, A. P.; WEBER, L. N. D. A adoção na mídia: revisão da literatura nacional e internacional. Paidéia. Ribeirão Preto, SP, 2003, v.13, n.25.

GOLSE B. Du corps à la pensée. Paris. PUF, col. Le fil rouge, 1999.

GOMES, I. C.; IYAMA, R. Atendimento breve de orientação psicanalítica a pais de crianças adotivas. Boletim de Psicologia, 2001, v.LI, n.114, 109-121.

GOMES, I. C.; MONACO, G. F. C. Configuração das famílias adotivas no Brasil: a interface do jurídico com o psicológico. Revista Escola Paulista de Direito Civil. São Paulo, 2005, v. 1, n. 1, p. 345-361.

GREEN, A. A mãe morta, 1980. Em: A.GREEN. Narcisismo de vida, narcisismo de morte. São Paulo: Editora Escuta, p.247-282,1988. 
GUTTON, P. (2006). Parentalité. Revue Adolescence, v.24, n.1, 9-32.

HAMAD, N. (2001). L' enfant adotif et sés familles. Paris : Éditions Denoël.

HOUZEL, D. As implicações da parentalidade. Em: L., SOLIS-PONTON (org.). Ser pai, ser mãe - Parentalidade: Um desafio para o terceiro milênio. São Paulo: Casa do Psicólogo, 2004.

KERNBERG, P. F. Child Analysis with a severely disturbed adopted child. International. Journal of psychoanalytic psychotherapy, 1985, v. 11. 277-299.

KERNBERG, P. F. Algumas reações contratransferenciais no tratamento de crianças e pais adotivos. Revista Brasileira psicanalítica, 1978, v. 12, 439-448.

KLEIN, M. O papel da escola no desenvolvimento da criança, 1923. Em: M. KLEIN. Amor, culpa e reparação. Rio de Janeiro: Imago, 1996, pp 82-99.

LADVOCAT, C. A terapia da família adotiva. Revista Brasileira de Terapia família. ABRATEF, 2010, v.2, n.1, 96-104.

LADVOCAT, C. Adoção e não-adoção: devolução e reintegração da criança adotiva ao abrigo. Em: R. M., MACEDO (Org.). Terapia familiar no Brasil na última década. São Paulo: Roca, 2008, 588-596.

LAPLANCHE; PONTALIS. Vocabulário de Psicanálise. 4.ed. São Paulo: Martins Fontes, 2001.

LEBOVICI, S. On intergenerational transmission: filiation from afiliation. Infant Mental Health Journal, 1993, v. 14, n. 4, 260-272.

LEE FU; MATARAZZO, E. B. Prevalência de adoção intra e extrafamiliar em amostras clínica e não-clínica de crianças e adolescentes. Revista Brasileira de Psiquiatria. São Paulo, 2001, v.23, n.3.

LEGENDRE, P. L'inestimable objet de la transmission - Etude sur Le príncipe généalogique en Occident. 2.ed. Paris: Fayard, Leçon IV, 1985, 409 p.

LEGENDRE, P. Filiation - Fondement généalogique de la psychanalyse para Alexandra Papageorgiou-Legendre. Paris: Fayard, Leçon IV, 1990/2004, 235 p.

LEGENDRE, P. Les enfants du texte: étude sur la fonction parentale des États. Paris: Fayard, 1992, 469 p.

LEVINZON, G. K. A criança adotiva na psicoterapia psicanalítica. São Paulo: Editora Escuta, 2000.

LEVY, L. Adoção internacional: filiação e processo de luto. Em: T. FÉRESCARNEIRO (org.). Casal e família: permanências e rupturas. São Paulo: Casa do Psicólogo, 2009, 59-70. 
LEVY, L.; FÉRES-CARNEIRO L'adoption: entre fantasme familiaux et réalité juridique. Revue Le divan familial, 2001, n.6, 83-93.

LEVY- SOUSSAN, P. La filiation à l'épreuve de l'adolescence. Revue Adolescence, 2006, v.24, n.1, 101-110.

LOPES, H. P. Gerar/ ter um filho: o processo de reprodução assistida como inclusão de terceiros. Em: R. M., MACEDO (Org.). Terapia familiar no Brasil na última década. São Paulo: Roca, 2008, 212-220.

MAGALHÃES, A. S. Conjugalidade e parentalidade na clínica com famílias. Em: T. FÉRES-CARNEIRO (org.). Casal e família: permanências e rupturas. São Paulo: Casa do Psicólogo, 2009, 205-217.

MARINOPOULOS, S.; SELLENET, C.; VALlÉE, F. Moïse, oedipe, superman... de l'abandon à l'adoption. Paris: Fayard, 2003, 352p.

MARTY, F. Adolescência, violência e sociedade. Ágora, 2006, 9, 119-131.

MONEY-KYRLE, R. Obra selecionada de Roger Money-Kyrle. São Paulo: Casa do Psicólogo, 1978, 486p.

MORETTO, C. C.; TERZIS, A. O mito e o grupo: algumas compreensões psicanalíticas. Revista SPAGESP, Ribeirão Preto, 2010, v. 11, n. 2.

NICOLLETTI, M. A. Q. Processos de Intersubjetivação na adolescência: o papel da família. Em: C. GOMES; M. I. FERNANDES; R. B. LEVISKY (Orgs.). Diálogos psicanalíticos sobre família e casal. São Paulo: Zagodoni, c. 5, 2012, 239p.

OGDEN, T. (1994). Os sujeitos da Psicanálise. São Paulo: Casa do Psicólogo, 1996.

OSÓRIO, L. (1989). Adolescência Hoje. Porto Alegre: Artes Médicas.

OUTEIRAL, J. (2008). Adolescer. Rio de Janeiro: Revinter, 3 ed., 184p.

OUTEIRAL, J. W. Bion e D. Winnicott: cogitações. Em: J., OUTEIRAL; S. HISADA; R. GABRIADES (orgs.). Winnicott - seminários paulistas. São Paulo: Casa do Psicólogo, 2001, 49-54.

OUTEIRAL, J.; ARAÚJO, S. M. B. Winnicott e a adolescência. Em: Outeiral et al. (orgs.). Winnicott: seminários paulistas. Casa do Psicólogo: São Paulo, 2001

PALHARES, M. C. A. Adolescência: uma visão psicanalítica. Em: A. MELGAÇO; J. OUTEIRAL; N. ARMONY. (orgs.). Winnicott - Seminários Cariocas. Rio de Janeiro: Revinter, 2008. 
PASSOS, M. C. Nem tudo que muda, muda tudo: um estudo sobre as funções da família. Em: T. FÉRES-CARNEIRO (org.). Família e casal: efeitos da contemporaneidade. Rio de Janeiro: Editora PUC-Rio, 2005, 11-23.

PEITER, C. Adoção: vínculos e rupturas: do abrigo à família adotiva. São Paulo: Zagodoni Editora, 2011, 128p.

PIRES, E. K. P. Talassemia e o ciclo vital. Em: R. M., MACEDO (Org.). Terapia familiar no Brasil na última década. São Paulo: Roca, 2008, 221-231.

PUGET, J. Transferência, contratransferência e interferência . Em: I. C. GOMES; M. I. FERNANDES; R. B. LEVISKY (Orgs.). Diálogos psicanalíticos sobre família e casal. São Paulo: Zagodoni, 2012, 239p.

QUEIROZ, E. F. O "estranho" filho adotivo uma leitura clínica do unheimlich na adoção. Revista Latinoamericana de Psicopatologia Fundamental, 2004, v.VII, n.4, 100-111.

RACAMIER, P. C. La mére et l'enfant dans lês psychoses du post-partum. L'evolutionary Psychiatry, 1961, v.26, n.4, 525-569.

ROTENBERG, E. Adopción : Construyendo nuestra família. Buenos Aires: Lugar Editorial, 2011.

ROUDINESCO, E.; PLON, M. (1998). Dicionário de Psicanálise. Rio de Janeiro: Jorge Zahar.

SAVIETTO, B. B. Adolescência: ato e atualidade. Curitiba: Juruá, 2010, 96p.

SCHEJTMAN, J. A. Psicopatología [en] [de] la adopción. Boletin de Psicoanalisis, 1990, v.XII, nº1, p.173-186.

SCHETTINI, S. S. M.; AMAZONAS, M. C. L. A.; DIAS, C. M. S. B. Famílias adotivas: identidade e diferença. Psicologia em estudo, 2006, v. 11, n.2.

SILVA, C. L. R. Filhos da esperança: Os caminhos da adoção e da família e seus aspectos psicológicos. Rio de Janeiro: Agbook, 2011, 127p.

SINGLY, F. Sociologia da Família Contemporânea. Rio de Janeiro: FGV, 1993/2007.

SOLIS-PONTON, L. A construção da parentalidade. Em: L., SOLIS-PONTON (org.). Ser pai, ser mãe - Parentalidade: Um desafio para o terceiro milênio. São Paulo: Casa do Psicólogo, 2004.

SOUZA, H. P.; CASANOVA, R. P. S. Adoção: o amor faz o mundo girar mais rápido. Curitiba: Juruá, 2011.

TRINDADE-SALAVERT, I. (org.). Os novos desafios da adoção: Interações psíquicas, familiares e sociais. Rio de Janeiro: Companhia de Freud, 2010, 185p. 
WEBER, L. N. D. Aspectos psicológicos da adoção. Curitiba: Juruá, 2001.

WEBER, L. Critérios de seleção de pais adotivos: em discussão. Interação em Psicologia. Curitiba, 1997, v.1 p.123-137.

WEBER L.; DESSEN, M. A. Pesquisando a família - instrumentos para coleta e análise de dados. Curitiba: Juruá Psicologia, 2009, 237p.

WINNICOTT, D. W. O ambiente e os processos de maturação: estudos sobre a teoria do desenvolvimento emocional. Porto Alegre: Artmed, 1983.

WINNICOTT, D. W. A experiência mãe-bebê de mutualidade, 1969. Em: C. WINNICOTT (Org.). Explorações psicanalítica. 2.ed. Porto Alegre: Artmed, c.2, 2007, 195-202.

WINNICOTT, D. W. A família e o desenvolvimento individual. 4.ed. São Paulo: Martins Fontes, 1965/2011, 247p.

WINNICOTT, D. W. Objetos transicionais e fenômenos transicionais, 1951. Em: D. W., WINNICOTT. Da pediatria à psicanálise. Rio de janeiro: Imago, 2000.

WINNICOTT, D. W. A agressividade em relação ao desenvolvimento emocional, 1950-55. Em: D. W. WINNICOTT. Da pediatria à psicanálise: obras escolhidas. Rio de Janeiro: Imago, 2000.

WINNICOTT, D. W. O ódio na contratransferência, 1947. In: D. W. WINNICOTT, Da pediatria à psicanálise: obras escolhidas. Rio de Janeiro: Imago, 2000.

ZORNIG, S. Transmissão psíquica uma via de mão dupla? Em: T. FÉRESCARNEIRO (org.). Casal e família: permanências e rupturas. São Paulo: Casa do Psicólogo, 2009, 25-39. 


\section{Anexo I}

\section{ROTEIRO INVISÍVEL DA ENTREVISTA COM OS PAIS ADOTIVOS}

1. A experiência de ser pai (mãe) adotivo.

2. Relação entre pais e filho.

3. Período da adolescência do filho (diferenças, surpresas, dificuldades).

4. Vivência da própria adolescência (lembranças significativas, relações com os pais)

5. Decisão da adoção (motivações, expectativas, história do processo)

6. Chegada do filho adotivo (surpresas, dificuldades, rede familiar)

7. A infância do seu filho (temperamento, lembranças significativas)

8. Revelação da adoção (época, processo, reação do filho)

9. Expectativas em relação ao futuro do filho. 


\section{Anexo II}

\section{APRESENTAÇÃO DE PESQUISA}

Título da pesquisa: Parentalidade e filiação adotivas

Instituição de origem: Pontifícia Universidade Católica do Rio de Janeiro

Doutoranda: Psicóloga Rebeca Nonato Machado CRP: 05/31528

Orientadora: Prof ${ }^{a}$. Terezinha Féres-Carneiro

Esta é uma pesquisa de Doutorado sobre pais adotivos de filhos que estejam na passagem pela adolescência. Pretendemos, com este estudo, compreender melhor as questões relacionadas ao exercício das funções parentais e à experiência de ser pai/mãe durante a adolescência, em famílias que vivenciaram o processo de adoção.

Precisamos entrevistar pais e mães adotivas de filhos que, atualmente, estejam entre 13 e 18 anos de idade. Como critério, decidiu-se que serão entrevistados pais que adotaram seus filhos quando os mesmos estavam com no máximo 10 anos de idade. Outro critério será o fato de a adoção não ser um segredo na família.

A pesquisa é realizada a partir de uma entrevista gravada com cada participante, em um local adequado e de preferência deste último. Todas as informações têm caráter confidencial, portanto, a identidade dos entrevistados será mantida em sigilo.

A participação é voluntária, o participante estará livre para interromper a entrevista quando assim desejar; recusar-se a responder perguntas ou falar de assuntos que lhe possam causar qualquer tipo de constrangimento. As perguntas abordadas na entrevista envolverão temas sobre relacionamento entre pais e filhos, questões da adolescência e processo de adoção.

A adesão dos participantes contribuirá para conhecermos mais sobre a parentalidade e a filiação adotiva na vivência do período da adolescência.

Os interessados em participar desta pesquisa, por favor, entrem em contato com Rebeca N. Machado, pelos números X ou Y (consultório), ou por email Z. 


\section{Anexo III}

\section{FICHA BIOGRÁFICA}

Entrevistado no:

1. Idade:

2. Gênero: 1 ( ) Masculino

2 ( ) Feminino

3.Cidade:

4. Escolaridade:

6. Profissão:

\section{Estado Civil:}

a.( )Solteiro(a) b.( )Casado(a), há quanto tempo?( )

c. ( )Mora junto, há quanto tempo? ( )

d. ( )Separado(a), há quanto tempo? ( )

e.( ) Recasado(a). Há quanto tempo? ( )

f.( ) viúvo(a), há quanto tempo? ( )

g.( ) Outro. Há quanto tempo? ( )

9. Quantos filho(a)s você tem e quais são as idades?

10. Atualmente, quem mora com você? 


\section{Anexo IV}

\section{TERMO DE CONSENTIMENTO LIVRE E ESCLARECIDO}

Instituição de origem: Pontifícia Universidade Católica do Rio de Janeiro Título da pesquisa: Parentalidade e filiação adotivas

Doutoranda: Rebeca Nonato Machado

Orientadora: Professora Terezinha Féres-Carneiro

Com este estudo pretendemos compreender melhor as questões relacionadas ao exercício das funções parentais e à experiência de ser pai/mãe durante a adolescência dos filhos, em famílias que vivenciaram um processo de adoção.

A pesquisa é realizada a partir de uma entrevista gravada e, posteriormente, transcrita, permanecendo sob a responsabilidade da pesquisadora todo e qualquer dado de identificação. Todas as informações têm caráter confidencial, portanto sua identidade será mantida em sigilo.

Sua participação é voluntária, estando livre para interromper a entrevista quando assim desejar; fazer as perguntas que julgar necessárias; recusar-se a responder perguntas ou falar de assuntos que lhe possam causar qualquer tipo de constrangimento.

Com sua adesão, você estará contribuindo para conhecermos mais sobre a parentalidade e a filiação adotiva na vivência do período da adolescência.

Assinando este formulário de consentimento, você estará autorizando a pesquisadora a utilizar, em ensino, pesquisa e publicação, as informações prestadas na entrevista, sendo preservada a identidade dos membros da família.

$\mathrm{Eu}$,

fui informado (a) sobre o estudo acima referido e compreendi seus objetivos. Tive a oportunidade de fazer perguntas e todas as minhas dúvidas foram respondidas a contento. Este formulário está sendo assinado voluntariamente, em duas vias, por mim, o que indica meu consentimento para participar desta pesquisa.

Assinatura do Entrevistado

Assinatura da Pesquisadora

Rio de Janeiro, 